\title{
Apoptosis and proliferation in basal cell carcinoma
}

Citation for published version (APA):

Tilli, C. (2003). Apoptosis and proliferation in basal cell carcinoma. [Doctoral Thesis, Maastricht

University]. Universiteit Maastricht. https://doi.org/10.26481/dis.20031030ct

Document status and date:

Published: 01/01/2003

DOI:

$10.26481 /$ dis.20031030ct

Document Version:

Publisher's PDF, also known as Version of record

\section{Please check the document version of this publication:}

- A submitted manuscript is the version of the article upon submission and before peer-review. There can be important differences between the submitted version and the official published version of record.

People interested in the research are advised to contact the author for the final version of the publication, or visit the DOI to the publisher's website.

- The final author version and the galley proof are versions of the publication after peer review.

- The final published version features the final layout of the paper including the volume, issue and page numbers.

Link to publication

\footnotetext{
General rights rights.

- You may freely distribute the URL identifying the publication in the public portal. please follow below link for the End User Agreement:

www.umlib.nl/taverne-license

Take down policy

If you believe that this document breaches copyright please contact us at:

repository@maastrichtuniversity.nl

providing details and we will investigate your claim.
}

Copyright and moral rights for the publications made accessible in the public portal are retained by the authors and/or other copyright owners and it is a condition of accessing publications that users recognise and abide by the legal requirements associated with these

- Users may download and print one copy of any publication from the public portal for the purpose of private study or research.

- You may not further distribute the material or use it for any profit-making activity or commercial gain

If the publication is distributed under the terms of Article $25 \mathrm{fa}$ of the Dutch Copyright Act, indicated by the "Taverne" license above, 


\section{Apoptosis and Proliferation}

in

\section{Basal Cell Carcinoma}


ISBN 90-9017400-1

(c) Claudia Tilli, Maastricht, 2003

Productie: datawyse 


\title{
Apoptosis and Proliferation
}

\author{
in \\ Basal Cell Carcinoma
}

Proefschrift

ter verkrijging van de graad van doctor aan de Universiteit Maastricht, op gezag van de Rector Magnificus,

Prof. Dr. A.C. Nieuwenhuijzen Kruseman, volgens het besluit van het College van Decanen, in het openbaar te verdedigen

op

donderdag 30 oktober 2003 om 14.00 uur

door

Claudia Tilli

Geboren op 27 mei 1976 te Maastricht 


\section{Promotores:}

Prof. Dr. H.A.M. Neumann

Prof. Dr. F.C.S. Ramaekers

\section{Co-promotor:}

Dr. G.A.M. Krekels

\section{Beoordelingscommissie:}

Prof. Dr. P.M. Steijlen (voorzitter)

Prof. Dr. W.D. Boeckx

Prof. Dr. M. Borgers

Dr. F. de Gruijl, Universiteit Leiden

Dr. B. Schutte

This thesis was prepared at the Department of Dermatology and the Department of Molecular Cell Biology, Research Institute Growth \& Development of the University of Maastricht.

Financial support for the publication of this thesis was provided by LEO Pharma BV, SanverTech, Smith \& Nephew Hoofddorp amd Laboratoires Vichy. 
Alles sal regt kom

In herinnering aan

Mama en Opa.

Voor Papa en Jan. 



\section{Aim of this thesis}

In this thesis the growth characteristics of basal cell carcinoma (BCC), the most common malignancy among Caucasians, is studied using molecular markers. BCC is a non-melanoma type of skin cancer and accounts for approximately $80 \%$ of all skin malignancies and increasing incidence. The malignancy is characterized by a slow growth and rare metastases, but occasionally the tumor can infiltrate and cause severe damage to the underlying tissue. Since its constantly increasing incidence and morbidity it becomes more and more opportune to explore possible new non-invasive therapies based on basic knowledge of $\mathrm{BCC}$.

Since in general tumor growth can be achieved by either deregulating the cell cycle, downregulation of cell loss, or both, this thesis concentrates on these processes of cell proliferation and programmed cell death (apoptosis). 



\section{Contents}

11 Chapter 1 General introduction

Molecular Cell Biology of Basal Cell Carcinoma

$37 \quad$ Chapter $2 \mathrm{~A}$ hairy issue

Human follicular stem cells: Their presence in plucked hairs and follicular cell culture

51 Chapter $3 \mathrm{Bcl}-2$ family

3.1 Bax expression and growth behavior of Basal Cell Carcinomas

673.2 Expression of pro- and anti-apoptotic members of the Bcl-2 family and associated proteins in Normal Human Skin and Basal Cell Carcinoma

79 Chapter 4 Nuclear lamins in the skin

Lamin expression in Normal Human Skin, Actinic Keratosis,

Squamous Cell Carcinoma and Basal Cell Carcinoma

93 Chapter 5 Therapy of Basal Cell Carcinoma

The garlic derived organosulfur component Ajoene decreases

Basal Cell Carcinoma tumor size by inducing apoptosis

109 Summary

111 Samenvatting

113 Dankwoord

115 Curriculum Vitae

117 Publications 



\section{Chapter 1: \\ General introduction}

\section{Molecular Cell Biology of Basal Cell Carcinoma}

CMLJ Tilli*.t, GAM Krekels*, MAM Van Steensel*, HAM Neumann", FCS Ramaekers $^{\dagger}$

Research Institute Growth \& Development (GROW), University of Maastricht, The Netherlands

*Dept. of Dermatology, University Hospital Maastricht, The Netherlands

†Dept. of Molecular Cell Biology, University of Maastricht, The Netherlands

IDept. of Dermatology \& Venereology, Erasmus University Rotterdam, The Netherlands 


\section{Introduction}

Basal cell carcinoma (BCC), a non-melanoma type of skin cancer, also called basalioma, basal cell epithelioma, rodent ulcer and Jacobs' ulcer, was first described in $1824^{1}$ and is the most common cancer amongst Caucasians ${ }^{2}$. BCC accounts for approximately $75 \%$ of all skin cancers. Mortality rates are relatively low $^{3}$, but BCC may occasionally grow aggressively causing extensive tissue destruction ${ }^{4}$. Its ability to metastasize is low $(<0.1 \%)^{5}$. Metastasis to lymph nodes, lung, bone and liver has been described ${ }^{6,7}$.

BCCs can be subdivided according to their differences in histological appearance ${ }^{8,9}$. The major histological patterns comprise nodular, micronodular, superficial and morpheaform BCC. The nodular type is characterized by a rounded mass of neoplastic cells with well-defined peripheral contours and peripheral palisading is well developed. The superficial type is defined by one or more tumor foci that extend from epidermis into the papillary dermis. Peripheral palisading occurs and the peripheral contours are smooth. The micronodular subtype is defined as small nodules and usually peripheral palisading is present. The morpheaform subtype demonstrates tumor islands of varying size with irregular outline and spiking configuration. Peripheral palisading is poorly developed. Mixed types of these histological patterns may occur, with the nodular-micronodular combination being the most common ${ }^{10}$. Furthermore, BCC with more nodular type in the center of the malignancy and morpheaform type at the periphery can occur. Finally, an adenoid pattern of BCC is seen in 1$7 \%$ of the tumors and is mainly associated with the nodular type $\mathrm{BCC}^{11}$. Nodular $(\sim 60 \%)$ and superficial ( $25 \%)$ BCCs are often considered as non-aggressive subtypes, whereas morpheaform ( 2\%) and micronodular ( 15\%) BCCs are often referred to as aggressive subtypes, and are associated with a higher risk of recurrence ${ }^{12}$.

\section{Risk factors}

The risk for development of $\mathrm{BCC}$ is associated with several patient dependent, but also environmental factors.

\section{- Environmental risk factors}

BCCs generally occur on sun-exposed areas of the body ${ }^{13}$ and high-risk patients are often fair-skinned with a history of burning, not tanning, when exposed to strong sunlight ${ }^{14}$. Male gender, older age and number of previous second-degree sunburns are also factors indicating a higher risk for development of $\mathrm{BCC}^{15}$. Corona et al. ${ }^{16}$ showed in 2001 that there is a significant association between BCC development and recreational sun exposure during childhood and adolescence, as well as a strong relation with family history of skin cancer. Patients with a BCC located on the trunk are at increased risk of developing multiple BCCs, and these tumors develop at a faster rate than BCCs located elsewhere on the body ${ }^{17}$. Grossman et al. ${ }^{18}$ showed that there is a correlation between UV-B exposure and development of skin cancer. However, the significant number of BCCs arising on non-sun-exposed areas of the body 
suggests that other risk factors may play a role in the development of $\mathrm{BCC}^{19}$. Diepgen et al. ${ }^{20}$ found that chemical carcinogens such as arsenic, coal tar products and psoralens as well as ionizing radiation increase the risk of nonmelanoma skin cancer. Combination of UV irradiation and arsenic exposure lead to an impaired process of nucleotide excision repair ${ }^{21}$. Excessive exposure to psoralen during UVA-treatment in psoriasis patients also results in an increased risk for $\mathrm{BCC}^{22}$. Prior non-diagnostic $\mathrm{X}$-ray treatment for skin conditions also enhanced the risk for $\mathrm{BCC}^{19}$. Furthermore, several authors demonstrated an association between infection with the oncogenic types of human papilloma virus (HPV) and development of $\mathrm{BCC}^{23-25}$, while Harwood et al. ${ }^{26}$ showed that HPV could abrogate UV-induced apoptosis. Furthermore, HPV DNA was detected in BCC patients by Barr et al. ${ }^{23}$ and Weinstock et al. ${ }^{25}$, suggesting HPV infection as a risk factor for developing BCC. With respect to the relation between smoking and skin cancer development, De Hertog et al. ${ }^{27}$ showed an association with squamous cell carcinoma but not BCC, while Boyd et al. ${ }^{28}$ recently proved that an association exists between smoking and $\mathrm{BCC}$ in young women. Furthermore, exposure to fiberglass dust and dry cleaning agents also enhance the risk for BCC development ${ }^{19}$.

\section{- GST Polymorphism}

Genes that mediate detoxification processes, including individual responses to UV irradiation by protecting from oxidative stress, are likely candidates for susceptibility genes for $\mathrm{BCC}^{29}$. For example, glutathione S-transferase (GST) enzymes are part of the cells' defense mechanism against numerous harmful chemicals produced endogenously and in the environment ${ }^{30}$. UV jrradiation causes oxidative stress in the skin, which leads to lipid peroxidation and DNA hydroperoxide formation ${ }^{31}$. GST is responsible for the disposal of these potential mutagens ${ }^{32}$. Cytosolic GST activity in mammalian tissues is due to the presence of multiple GST isozymes, which can be assigned to five classes e.g. $\alpha, \mu, \pi, \sigma$ and $\theta^{33}$. In human skin, GST activity can be found predominantly in sebaceous glands and in the outer root sheath of hair follicles, the $\pi$-class of GST being the predominant isozyme ${ }^{34}$. GST- $\pi$ has been suggested to be an oncofetal protein that is re-expressed during carcinogenesis ${ }^{35}$. A significant increase in skin tumorigenesis is observed in mice lacking $\pi$-class GST $^{36}$. In humans, GST- $\pi$ is mainly expressed in malignant melanomas ${ }^{37}$, whereas BCCs show only a weak expression of the protein ${ }^{38}$. Several polymorphisms in GST family members exist $^{33,39}$ and have been associated with impaired detoxification, thus influencing the risk for several cancers, including nonmelanoma skin cancer ${ }^{40.41}$. A GSTT1 null genotype is associated with high UV sensitivity ${ }^{42}$, and GSTM1 null genotype also predisposes for BCC due to its role in defense against UV-induced oxidative stress ${ }^{29.43}$. Polymorphism of GSTM3 was also shown to increase risk for $\mathrm{BCC}^{44}$. Another genetic factor involved in detoxification of photosensitizing agents, and thus involved in BCC carcinogenesis is polymorphism of CYP2D6 (the gene encoding for cytochrome $\mathrm{P} 450$ ), which is correlated with increased number of $\mathrm{BCC}^{33}$. Furthermore, CYP2D6 EM is associated with a multiple presentation phenotype of $\mathrm{BCC}^{45.46}$ and these patients are also at higher risk for developing $\mathrm{BCC}^{47}$. 


\section{- Hereditary predisposition}

In rare cases individuals can show an inherited predisposition for BCC. In 1973, Milstone and Helwig ${ }^{48}$ noted that patients with Xeroderma Pigmentosum (XP), a group of rare autosomal recessive disorders characterized by severe photosensitivity due to various defects in the DNA repair of UV-induced lesions, are prone to develop cutaneous cancers, mostly squamous cell carcinoma (SCC) but also $\mathrm{BCC}^{49-51}$. There are several variants of the disease, all caused by a different genetic defect in nucleotide excision repair (NER), global genome repair, transcription coupled repair or combinations thereof. Some of the genes involved are essential components of the TFIIH transcription complex; their absence is associated not only with UV sensitivity but also with sometimes severe neurological defects and growth retardation (as in de SanctisCacchione $)^{52}$. Interestingly, at least two types of XP are caused by defects in DNA helicases that are involved in NER and in transcription. Werner and Bloom syndromes are hereditary skin cancer disorders that are associated with helicase defects but, curiously, not with the development of basal cell carcinomas $^{53.54}$. Rothmund-Thomsen syndrome, that in some cases is caused by defects in a DNA helicase, does predispose to $\mathrm{BCC}^{55}$. The reason for this difference is poorly understood. The expression patterns of helicases may play a role but it is not clear why helicases should be tissue-specific. Chromosomal breakage disorders such as ataxia teleangiectasia and Nijmegen Breakage Syndrome do not predispose to BCC. Neither does Li-Fraumeni syndrome, which is caused by germline mutations in the p53 gene, or dyskeratosis congenital, a disorder associated with failure to maintain telomeres. Why these forms of genomic instability do not seem to be causally related to BCC is subject to speculation.

Moreover, patients with the nevoid BCC syndrome (NBCCS) or Gorlin syndrome $^{56}$, also show a rapid development of numerous tumors at young age. Whereas XP is an autosomal recessive disorder, NBCCS is an autosomal dominant disorder ${ }^{57}$. A human homologue to the Drosophila segment polarity gene patched, PTCH is mutated in NBCCS patients, suggesting a contribution to the tumorigenesis ${ }^{58,59}$. Since NBCCS patients normally inherit one mutated copy of the PTCH gene, tumors are likely to arise after inactivation of the remaining allele ${ }^{60}$. Haplo-insufficiency of the PTCH gene is probably responsible for the dysmorphisms. XP patients and sporadic BCCs may also show mutations in the PTCH gene ${ }^{61-63}$. The PTCH gene product is involved in the so-called Sonic Hedgehog-signaling pathway, which is involved in embryonic development ${ }^{64}$. Sonic hedgehog (shh) is expressed in the Hensen node, the floor plate of the neural tube, the early gut endoderm, the posterior limb buds and throughout the notochord, and encodes a signal responsible for patterning the early embryo ${ }^{65-67}$. At the cell surface, patched and smoothened form a receptor complex for sonic hedgehog, which is a secreted molecule that influences the differentiation of a variety of tissues such as brain, spinal cord, limbs and axial skeleton ${ }^{68}$. When sonic hedgehog binds to patched, it releases smoothened, a transmembrane signaling protein, which is inhibited by binding to patched protein ${ }^{69}$. High frequency of mutations in smoothened and patched in BCCs, resulting in continuous activation of target genes, indicates that a disturbed hedgehog pathway, resulting in excessive signaling, may be an important carcinogenic route ${ }^{70}$. UV irradiation enhances BCC development in 
PTCH mutated mice ${ }^{71}$. Of the sporadic BCCs $20 \%$ show smoothened mutations $^{72}$ and $30-40 \%$ patched mutations ${ }^{62}$. In XP patients, the majority $(\sim 80 \%)$ of PTCH mutations are UV-induced ${ }^{73}$, more frequently than in sporadic $\mathrm{BCCs}^{62}$, where UV-signature mutations are seen in less than $50 \%^{74}$. PTCH2, which is $57 \%$ identical to PTCH1, also serves as a receptor for hedgehog and related factors ${ }^{75}$. Mutations occur in sporadic $\mathrm{BCC}^{76}$, and it has been shown that when PTCH1 is mutated, PTCH2 mRNA is upregulated ${ }^{75}$.

Finally, Rombo and Bazex syndromes are known to predispose to BCC. Both are characterized by the presence of numerous small cysts in the face chest, as well as by hypotrichosis. The cysts contain vellus hairs ${ }^{77.78}$. Rombo syndrome is distinguished by striking degeneration of elastic fibrils in sunlight-exposed areas causing dramatic skin alterations called atrophoderma vermiculatum ${ }^{77.78}$. In Bazex syndrome, so-called ice-pick scars are seen on the backs of the hands. This disorder is X-linked and has been mapped to Xq24-27. Rombo syndrome is probably autosomal dominant, but elsewhise very similar to Bazex.

\section{- Genetic changes}

The most common genetic aberrations in human skin cancers are found at the level of the p53 gene, which mediates cell cycle arrest after DNA damage ${ }^{79}$. The p53 gene encodes a phospho-protein that is involved in cell cycle control ${ }^{80}$. In response to cellular stress, for example DNA damage, p53 is activated through phosphorylation ${ }^{81,82}$. Mdm2 can associate with p53 and regulates its level and activity depending on the phosphorylation status of p53. When dephosphorylated, p53 can bind to mdm2 and is then being degraded through the ubiquitin-proteosome pathway ${ }^{83,84}$. In response to DNA damage, p53 is phosphorylated and becomes detached form $\mathrm{mdm} 2$, resulting in stabilization and activation of target genes regulated by $p 53^{85}$. The response to DNA damage is either growth arrest, senescence or apoptosis ${ }^{86}$. The relative cellular content of p53 determines the response following DNA damage; when the content is low to moderate, cells will go into cell cycle arrest to allow DNA repair, but when p53 levels are high, cells will progress to apoptosis ${ }^{87}$. P53 is capable of stimulating pro-apoptotic Bax expression ${ }^{88,89}$ (see also below). In normal skin, wild type (WT) p53 is not detectable but appears within 2 hours after UV irradiation, with peak levels at 24 hours after irradiation and again undetectable levels at 36 hours after irradiation ${ }^{90}$. Mutant p53 can accumulate in cells and p53 mutations have been detected in about half of all BCCs ${ }^{91,92}$. It was furthermore proven that histologically proven aggressive BCCs are significantly associated with increased p53 expression, most probably representing the mutated form. It is, however, strikingly that patients suffering from Li-Fraumeni syndrome do not show increased incidence of BCC. In BCC patients, a study comparing sunscreen users and non-users, it was shown that sunscreen users showed a significantly lower level of p53 mutations in their BCCs than nonusers93. Mutation-hotspots have been identified, with two-third of the mutations occurring at nine different $\operatorname{sites}^{94}$. Inactivation of p53 occurs predominantly by point mutation of one allele followed by loss of the remaining wild type allele ${ }^{95}$. The p53 gene shows UV-signature mutations i.e. predominantly $C(C)->T(T)$ conversions $^{94.96}$. In $33 \%$ of Korean BCC patients p53 mutations were detected ${ }^{61}$ and up to $50 \%$ of the Caucasian BCC patients showed this mutation ${ }^{91,92}$, thus suggesting that different ethnic factors play a role in BCC carcinogenesis. 
Although at the moment no explanation at the molecular level is available for this finding, polymorphisms in genes may be related to this phenomenon, as for example the MC1R gene, coding for the receptor of melanocortin 1 and involved in the regulation of pigmentation ${ }^{97}$. Polymorphism in this gene is associated with squamous cell carcinoma or melanoma in the Irish and Scottish population $^{98,99}$.

P63, a p53 homologue, encodes multiple products and is restricted to cells with high proliferate potential and absent from cells undergoing terminal differentiation $^{100}$. P63 has a nucleoplasmic distribution pattern in the basal compartment of stratified epithelia such as skin, tonsil, bladder and certain subpopulations of basal cells in prostate, breast, uterine cervix and bronchi ${ }^{101}$.

${ }^{103}$. P63 deficient mice have striking developmental defects such as absence or truncation of limbs, absence of hair follicles, teeth and mammary glands, and the skin lacks stratification and differentiation ${ }^{104}$. This indicates that p63 is essential for several aspects of differentiation during embryogenesis. Several isoforms of p63 can bind to p53 consensus-sequences and activate p53 targetgenes. Isoform TAp63 $\gamma$ is capable of inducing cell cycle arrest and apoptosis ${ }^{105}$. The $\Delta \mathrm{N}$ isoforms, lacking the $\mathrm{N}$-terminus, are unable to induce transcription, and have an anti-apoptotic effect by rendering p53 and TA isoforms inactive. $\mathrm{P} 63$ is only rarely mutated ${ }^{106}$. It was furthermore shown that p63 functions not only as a stem cell marker of keratinocytes ${ }^{107}$ but it also suggested that it maintains the stem cell phenotype ${ }^{108}$. In consistency with its basal cell localization in normal epidermis, BCC cells express p63 $3^{103,109}$. It was shown, that aberrant expression of p63 altered the UVB-induced apoptotic pathway suggesting that downregulation of this protein in response to UV irradiation is important in epidermal apoptosis ${ }^{110}$.

\section{- Immunosuppression}

Organ transplant recipients are considered to be at greater risk for development of malignancies because of the prolonged, often life long, immunosuppression therapy ${ }^{111-113}$. Skin cancer is the most common malignancy occurring in the setting of solid-organ transplantation and immunosuppression, and its incidence increases substantially with extended survival after transplantation ${ }^{114}$. Surprisingly, squamous cell carcinoma (SCC) occurs more frequently in transplant patients ${ }^{115}$, whereas in the general population BCC occurs 3-6 times more frequent than $\operatorname{SCC}^{116}$. It was shown in Australian heart transplant recipients that the number of skin cancers is significantly correlated with both age at transplantation and duration of follow-up ${ }^{197}$. In Europe, $40 \%$ of the renal transplant recipients develop skin cancer within 20 years after grafting ${ }^{118}$. Heart transplant recipients are at higher risk than kidney transplant recipients most probably due to the fact that they receive higher doses of immunosuppression agents $^{119}$, but it cannot be excluded that the different types of immunosuppressive agents have different effects in this respect.

People suffering from AIDS also have shown an elevated risk for the development of $\mathrm{BCC}^{120}$ and HIV patients with BCC show more frequently blue eyes, blond hair, family history and extensive prior sun exposure ${ }^{121}$.

The major histocompatibility complex (MHC) genes code for membrane proteins that play an important role in controlling immune responses ${ }^{122}$. There are two classes of genes, Class I (HLA-A, -B, -C) and Class II (HLA-DR, -DQ, DP), 
which play a role in host defense against development and spread of tumors ${ }^{123}$. For example, loss of Class I antigens is related to tumor progression in melanomas ${ }^{124}$. Furthermore, abnormalities in cell-mediated immunity have been reported in patients with multiple $\mathrm{BCCs}^{125}$. Whereas normal skin shows high levels of Class I molecules, BCC shows either complete absence or heterogeneous expression ${ }^{126}$. All Class I negative tumors were histologically proven aggressive, whereas all non-aggressive BCCs were class I positive. The low levels or absence of expression of Class I antigens may result in escape from recognition by cytotoxic $T$ cells, which then facilitates tumor growth ${ }^{127}$. Evidence for the involvement of HLA-genes in the development of skin cancer was provided by Bouwes Bavinck et al. ${ }^{128}$ These authors showed that the presence of HLA-DR7 and a decrease of HLA-DR4 are significantly associated with BCC. This corroborates the previous finding of Rompel et al. ${ }^{129}$ that HLADR4 is decreased in BCC, especially in patients with multiple BCCs located on the trunk ${ }^{130}$. The authors suggested a protective role for HLA-DR4 against development of BCC. HLA-DR1 is weakly associated with the development of multiple BCCs at an early age ${ }^{131}$. Furthermore, Bouwes Bavinck et al. presented two studies showing a correlation between HLA-A11 expression and skin cancer in immunosuppressed renal transplant recipients ${ }^{132,133}$. One of these studies showed that HLA-A11 was associated with resistance to skin cancer in renal transplant recipients ${ }^{132}$, while another study, in Australia, showed that renal transplant recipients with HLA-A11 had an increased risk for developing skin cancer ${ }^{133}$. This apparent discrepancy may be the result of different genetic background and differential environmental factors.

Although human papilloma viruses (HPV) has been associated strongly with malignant progression of warts to SCC and with epidermodysplasia verruciformis ${ }^{134}$, different oncogenic subtypes of the virus were found in $60 \%$ of BCCs from immunosuppressed patients in contrast to $36 \%$ of BCCs from nonimmunosuppressed patients, suggesting that these viruses may be involved in the development of $\mathrm{BCC}^{135}$. In renal transplant recipients with skin cancer HPV $5 / 8$ DNA could be detected ${ }^{23}$, and Weinstock et al. ${ }^{25}$ suggested immunosuppression to be a factor in BCC carcinogenesis by affecting HPV infection.

\section{Precursor cells}

Several cell types have been suggested to be the precursor cells or stem cells for BCC, i.e. interfollicular basal cells, basal keratinocytes from hair follicles or sebaceous gland cells ${ }^{136-138}$. In general stem cells have a relatively undifferentiated and slow cycling phenotype, but can be stimulated to proliferate and give rise to transient amplifying cells which have a limited proliferate potential ${ }^{139}$. Stem cells may be the target of carcinogens and as such play an important role in tumorigenesis. For example, one observation that suggests that stem cells are the most likely cells of origin for human skin cancer, is the fact that sunlight exposure in childhood may contribute to tumors many decades later $^{140}$. As suggested by Taylor et al. ${ }^{141}$ the ultimate source of stem cells in the skin is the hair follicle. These stem cells are most likely located in the bulge 
region of the outer root sheath (ORS) ${ }^{142}$. As a result, hair follicles play a potentially important role in skin homeostasis, wound healing and tumorigenesis ${ }^{139}$. Chemically induced BCCs in rats arise from hair follicles ${ }^{143}$, while in humans, BCCs can apparently arise from both follicular and interfollicular epidermis ${ }^{136}$. Histologically, BCCs may resemble hair follicles ${ }^{11}$, and may show characteristics from both bulge region stem cells and transient amplifying cells ${ }^{144}$. In particular, a small fraction of BCC may histologically resemble trichoepithelioma, a benign hair follicle tumor $^{145}$. Especially the suprabullar region of the ORS of the hair follicle shows an almost identical immunohistochemical profile ${ }^{137.146}$, suggesting a role for the lower ORS in the generation of BCC. The hair follicle hypothesis is furthermore supported by the fact that when a carcinogen is added in anagen-phase, in which the hair follicle bulge region cells undergo transient amplification, BCCs are generated more frequently ${ }^{147}$. Furthermore, BCCs seldomly occur on non-hairy skin ${ }^{144}$. Support for the hair follicle hypothesis can be found in the expression of the basal cell adhesion molecule B-CAM in normal and diseased $\operatorname{skin}^{148}$. The fact that this cell surface protein is preferably expressed in suprabasal cell layers and the outer root sheath of the hair follicle, and also shows high levels of expression in $B C C$, suggests BCC originating from hair follicles rather than from basal keratinocytes, which are negative for B-CAM in normal skin. BCC However, based on the lack of cytokeratin (CK) 15 expression in the tumor cells, BCCs do not differentiate towards hair bulge cells ${ }^{149}$.

In support of the interfollicular origin of BCC Howell et al. ${ }^{150}$ reported the tiny pits in the epidermis of palms and soles characteristic for Gorlin syndrome ${ }^{56}$ (also called nevoid basal cell carcinoma syndrome) occasionally show basaloid budding into the dermis, and have therefore been suggested to resemble tiny BCCs.

\section{Carcinogenesis}

Tumor formation results from a disruption of the normal balance between cell proliferation and cell death ${ }^{151}$. Three large categories of genes affect cellular proliferation and survival, i.e. growth promoting oncogenes, tumor suppressor genes and mutator or caretaker genes ${ }^{152}$. The normal counterparts of oncogenes, i.e. the proto-oncogenes, are crucial in regulating normal cell cycling and division, differentiation and apoptosis ${ }^{153-155}$. When these become mutated or amplified they can overcome the normal restraints of cell growth $^{156,157}$. Tumor suppressor genes negatively regulate cell growth or promote cell death, and mutations or deletions of such genes have been reported in various types of cancer ${ }^{158-160}$. Activation of proto-oncogenes and inactivation of tumor-suppressor genes leads to an accumulation of genetic abnormalities ${ }^{161}$. Defects in tumor suppressor genes appear to be more common than defects in oncogenes ${ }^{162}$. Mutator or caretaker genes maintain the genome integrity and when their function is altered, mutations can accumulate more frequently ${ }^{52}$. 


\section{- Proliferation versus differentiation in BCC}

Proliferation indices vary greatly for the different subtypes of $\mathrm{BCC}$, but in general relatively high percentages of proliferating tumor cells are found ${ }^{163-166}$. Based on immunohistochemical detection of the proliferation marker Ki-67 on average $20 \%$ of the cells in BCC are proliferating ${ }^{164,165,167,168}$. The proliferating cell nuclear antigen (PCNA) is present in $<10 \%$ of non-recurrent BCCs, while recurrent BCCs show PCNA expression in $>30 \%$ of the tumor cells ${ }^{169,170}$. In nodular and superficial $\mathrm{BCC}$ the proliferative activity is mainly restricted to the periphery of the tumor nests, whereas morphea-like tumors show a more scattered pattern of proliferating cells ${ }^{164,168}$. An explanation for the zonal distribution of proliferation-potent cells may be that tumor cells migrating towards the center of the tumor nests become more differentiated, or have less access to nutrients, resulting in lower proliferation potential ${ }^{171}$.

Markers for arrest of cell proliferation include the A-type lamins, also designated Statins ${ }^{172}$. Nuclear lamins are intermediate filament proteins that form a network at the nucleoplasmic site of the nuclear membrane and can be divided in two sub-types, i.e. A-type lamins (lamin A, lamin A $\Delta 10$ and lamin C) and B-type lamins (lamin B1 and lamin B2) ${ }^{173.174}$. Aberrant expression patterns of lamins have been described in cancer and it is thought that the nuclear matrix plays a role in carcinogenesis ${ }^{175}$. In general, A-type lamin expression is correlated with a non-proliferating, differentiated state of cells and tissues ${ }^{176}$, and therefore altered expression of A-type lamins can be expected in cancer. In BCC, it was recently reported by Venables et al. ${ }^{177}$, that the absence of lamin A correlated with rapid growth, while the absence of lamin C correlated with slow growth of this skin tumor. It was furthermore reported, that the expression of A- and Btype lamins varies with differentiation in normal epidermis ${ }^{178}$ and skin tumors ${ }^{178.179}$. These authors support the idea that expression of A-type lamins, but not B-type lamins is associated with the differentiation phenotype of the tumors. Recently, Tilli et al. ${ }^{180}$ reported four stages in BCC development based on different patterns of A-type lamin expression. Stage 1 comprises lamin A negative, Ki-67 positive BCCs, representing the origin of $\mathrm{BCC}$, while stage 2 comprises lamin A positive, Ki-67 positive BCCs. As tumor growth slows down, lamin $C$ is first re-located to the nucleolus in stage 3 and in stage 4 lamin C expression is largely diminished.

The fact that BCC show relatively high percentages of proliferating tumor cells is not in line with the clinical finding that BCC is in general slow-growing ${ }^{181}$. Therefore, the process of cell loss must be considered as an important factor in the net growth of BCC. Already in 1972, Kerr ${ }^{182}$ reported that a high apoptotic rate in BCC might account for the paradoxically slow growth rate. Furthermore, Mooney ${ }^{183}$ showed that indeed BCCs exhibit a high apoptotic rate as based on in situ end labeling.

\section{- Apoptosis in epidermis and BCC}

Apoptosis, a form of programmed cell death, is characterized by cell shrinkage and fragmentation ${ }^{184}$. Apoptosis is amongst others necessary for the correct development of an embryo ${ }^{185}$, and to eliminate auto-reactive lymphocytes ${ }^{186}$. Abnormal, unwanted or damaged cells are removed by apoptosis without the involvement of the immune system, but through rapid phagocytosis of apoptotic cells before lysis, which prevents inflammation ${ }^{187}$. In this respect the process of 
programmed cell death can be clearly distinguished form accidental cell death, i.e. necrosis.

During the different phases of apoptosis various sets of molecules act in an orchestrated fashion. These include:

1. Death ligands and death receptors. The family of death receptors is characterized by two to five copies of cysteine-rich extracellular repeats and a death domain within the intracellular carboxy-terminus of the receptor (the death domain $)^{188}$. When these death receptors are bound by ligand, apoptosis can be induced. Fas is an example of a type I transmembrane receptor which mediates apoptosis upon binding of the oligomerizing Fas Ligand (FasL) ${ }^{189}$. Fas is expressed on several different cell types, while expression of FasL is restricted to immune cells, including $\mathrm{T}$ and $\mathrm{B}$ lymphocytes, macrophages, and natural killer cells ${ }^{190,191}$. Ligation of FasL to Fas causes rapid death-inducing signaling complex formation, which recruits and activates pro-caspase-8, thus triggering the apoptotic caspase cascade (see below).

2. Bcl-2 protein family. Many studies concentrate on the Bcl-2 family of apoptosis-regulating proteins ${ }^{92,193}$. Bcl-2 was first discovered in B-cell lymphomas showing a $\mathrm{t}(14: 18)$ translocation ${ }^{194}$, resulting in a $\mathrm{Bcl}-2$ Immunoglobulin-heavy chain fusion-gene ${ }^{195}$. This leads to the over-expression of the anti-apoptotic Bcl-2 protein. The protein has been shown to suppress apoptosis induced by various stimuli, such as depletion of IL- 3 and IL-4 ${ }^{196,197}$, p53-induced apoptosis ${ }^{198}$, glucocorticoid treatment ${ }^{199}$, and c-myc induced apoptosis ${ }^{200}$. Bcl-2 expression has been localized to long-lived (stem) cells in self-renewing human tissues 153 . The protein is associated with the membranes of mitochondria, endoplasmatic reticulum and nucleus ${ }^{201}$, and bears 7 . phosphorylation sites of which ser70 is critical for the apoptosis suppressing function of $\mathrm{Bcl}-2^{202}$.

A large number of $\mathrm{Bcl}-2$ related proteins ${ }^{192,193,203,204}$ have been isolated, which can act either as apoptosis-inducing (e.g. Bax, Bcl-xs) or apoptosis-suppressing agents $(\mathrm{Bcl}-\mathrm{xl})$. Heterodimerization between these family members determines whether a cell will die or not to die 205,206 .

3. Caspases. The aspartate-specific cysteine protease (caspase) cascade appears to be the main pathway for clearance of cellular constituents during the execution phase of apoptosis ${ }^{207}$. Several human caspases have been identified that share similarities in amino acid sequence, structure and substrate specificity $^{208,209}$. Caspases show a high specificity for the conserved QACXG sequence, resulting in the cleavage after aspartic acid (Asp) residues ${ }^{210}$. The caspase family comprises apoptotic initiators (e.g. caspase-2, $-8,-9$ and -10 ) and apoptotic executioners (e.g. caspase- $-3,-6$ and -7$)^{208}$. Caspase- 3 seems to be responsible for the majority of apoptotic effects, and is supported by caspase- 6 and -7 . These three executioner caspases are important in the cleavage and degradation of several substrates, target-proteins that are involved in RNA splicing. DNA repair, and scaffolding of the cytosol and the nucleus. Upon induction of apoptosis, caspase-3 cleaves the inhibitor of the caspase-activated DNAse, resulting in degradation of DNA into oligonucleosomal fragments $^{211.212}$. Lamin $A$ is cleaved by caspase- $6^{213,214}$, while also cytoskeletal filaments such as cytokeratins are cleaved by caspase- $6^{215}$. 
The externalization of phosphatidyl-serine at the cell membrane during apoptosis is also caspase-dependent ${ }^{216}$. The nuclear matrix protein poly(ADPribose) polymerase (PARP) is also proteolysed by caspases during apoptosis ${ }^{217}$.

Inhibitors of apoptosis proteins (IAPs), which are constitutively present in cells $^{218.219}$, for example bind to and inhibit caspase- 3 and -7 as well as procaspase- 9 , but not capase $-1,-6,-8$ or -10 .

When apoptosis occurs inappropriately it may cause degeneration of normal tissue architecture or function. On the other hand, when apoptosis fails to occur this can give rise to deregulation of tissue homeostasis, as a result of which neoplasms can arise.

Apoptosis in the epidermis is a common phenomenon. In the morphogenesis of human fetal skin and maintenance of adult epidermis apoptosis plays a pivotal role $^{220}$. For example, the apoptosis machinery is activated during the normal terminal differentiation process in keratinocytes ${ }^{221}$. In fetal skin, cells undergoing apoptosis are present in several epidermal cell layers, whereas in neonatal epidermis these are found in the terminally differentiating granular cell layer, and in adult skin also the spinous cells show occasional apoptosis ${ }^{220}$. Furthermore, apoptosis occurs upon excessive UV light exposure, resulting in un-repairable DNA damage ${ }^{222}$. A significantly negative correlation between the expression of either p53 or $\mathrm{Bcl}-2$ with the development of $\mathrm{BCC}$ has been described previously ${ }^{223}$. Mutation of p53 or over-expression of $\mathrm{Bcl}-2$ is sufficient to enhance formation of BCC by suppressing apoptosis ${ }^{224,225}$.

Altered expression of $\mathrm{Bcl}-2$ family member proteins in non-melanoma skin cancer has been reported extensively before ${ }^{226}$, suggesting that deregulation of expression of these proteins may be a possible explanation of the indolent growth-behavior of $\mathrm{BCC}^{168.227}$. $\mathrm{Bcl}-2$ is in general homogeneously expressed in $\mathrm{BCC}^{168.228-230}$, while also the apoptosis-inducing Bax protein is expressed at high levels ${ }^{168.226}$. These data clearly show that a considerable proportion of cells in BCC are in principle capable of undergoing apoptosis, corroborating the earlier finding of Mooney ${ }^{183}$.

Another apoptosis inhibitor protein called survivin is expressed in $81 \%$ of BCC, whereas it is not detected in normal skin, suggesting a contribution to the progression of $\mathrm{BCC}^{231}$.

Also Fas-mediated apoptosis may be important for skin homeostasis. Hill et al. ${ }^{232}$ suggested that deregulation of Fas-FasL interactions may be central to the development of skin cancer. In normal skin, Fas is expressed in cytoplasmic membranes of the basal cell layer, while after sun exposure the expression of Fas is upregulated in the entire epidermis. After further UV exposure, Fas expression is again down regulated, resulting in a negative staining in $\mathrm{BCCs}^{233}$. BCCs express however strongly and diffusely FasL, providing evidence for an escape from local immune surveillance by the induction of apoptosis in the peripheral T lymphocytes ${ }^{234}$. 


\section{Induction of apoptosis in therapy of BCC}

Different surgical and non-surgical therapies are available for the treatment of $\mathrm{BCC}^{235}$. Medical history of the patient, age, tumor localization and size, physical condition, histological outcomes and cosmetic aspects will eventually determine the choice of therapy. Furthermore, Telfer et al ${ }^{236}$ published guidelines for the management of BCC, presenting evidence-based guidance for treatment. In spite of the fact that surgical excision is still the most prominent therapy used, non-invasive therapies like photodynamic therapy (PDT) ${ }^{237}$ or topical application of 5 -fluorouracil ${ }^{236}$ are currently becoming more and more interesting in selective cases, especially because of the improved cosmetic outcome.

Many currently used anti-neoplastic agents exert their therapeutic effects through the induction of apoptosis. Different cell types vary profoundly in their susceptibility, suggesting the existence of distinct cellular thresholds for apoptosis induction $^{239}$. For example, BCC cells over-expressing IL-6 are resistant to UV irradiation and PDT-induced apoptosis ${ }^{240}$. Furthermore, it was shown that de novo p53 synthesis or stabilization of p53 is essential to induce apoptosis in $\mathrm{BCC}^{241}$. Over-expression of the anti-apoptotic $\mathrm{BCl}-2$ has also been linked to resistance of cancers to various chemotherapeutic drugs ${ }^{242}$.

In BCC Interferon (IFN)- $\alpha$ induces apoptosis and is thus effective in the treatment ${ }^{243}$. Untreated BCC cells express FasL but not the receptor, but in IFNalpha-treated BCC patients the tumor cells express both FasL and receptor, whereas the peritumoral infiltrate mainly consists of Fas-receptor-positive cells $^{244}$. Upon IFN- $\alpha$ treatment the BCCs therefore most likely regress through apoptosis.

Topical treatment of BCC with 5-fluorouracil (5-FU) has also been proven to be very successful. Up to $90 \%$ of treated BCCs show regression when $5-\mathrm{FU}$ is applied in a phosphatidyl choline-based cream $^{245}$ or when it is locally injected in an epinephrine containing gel ${ }^{238}$. The regression of the tumors treated with 5FU is probably caused by enhancing apoptosis in the tumor cells ${ }^{246}$.

Recently, Nakaseko et al. ${ }^{247}$ reported that apoptosis is involved in regression of the lesion after photodynamic therapy (PDT) in Actinic Keratosis. This therapy is also used for treatment of $\mathrm{BCC}^{248}$, where tumor cells may also undergo apoptosis.

Retinoids (vitamin A metabolites and analogs) have also been shown to have suppressive effects on tumor promotion, and the mechanism appears to be associated with modulation of growth, differentiation and apoptosis ${ }^{249}$.

Also more and more phytochemicals are being applied in cancer prevention and therapy ${ }^{250}$. Recently, Levin and Maibach ${ }^{251}$ published an overview of alternative drugs and treatments in dermatology. It was shown that by application of green tea polyphenolic fractions reduced the UV-induced erythema, gave rise to a decrease in sunburns and could also reduce UV-induced mutations in DNA ${ }^{252}$. Oral and topical application of black tea extracts also decreased photochemical damage to the $\mathrm{skin}^{253}$. Furthermore, in mice bearing skin tumors, tumor growth was inhibited by $70 \%$ after treatment with black tea, which was established by inhibition of proliferation and enhanced apoptosi ${ }^{254}$. Ajoene, an organosulfur compound of garlic ${ }^{255}$, has been shown to induce apoptosis in human promyeloleukemic cells ${ }^{256}$. Recently, it was shown that ajoene can induce 
apoptosis in the human keratinocyte cell line $\mathrm{HaCat}$ and has a diminishing effect on $\mathrm{BCC}$ in vivo by downregulating the expression of the apoptosis-suppressing protein $\mathrm{Bcl}-2$ (Tilli in press).

Based on the foregoing it is our firm believe that the development of future therapies for BCC will be strongly influenced by attempts to specifically induce apoptosis in these tumor cells. 


\section{References}

Jacob A. Observations respecting an ulcer of peculiar character, which attacks the eyelids and other parts of the face. Dublin Hosp. rep. 1824; $4: 232-9$.

Marks R. An overview of skin cancers: incidence and causation. Cancer 1995; 75: $607-12$.

Gloster HM, Brodland DG. The epidemiology of skin cancer. Dermatol. Surg. 1996; 22: 217-26.

Leffell DJ, Headington JT, Wong DS et al. Aggressive growth basal cell carcinoma in young adults. Arch. Dermatol. 1991; 127: 1663-7.

von Domarus HV, Stevens PJ. Metastatic basal cell carcinoma: report of five cases and review of 170 cases in the literature. J. Am. Acad. Dermatol. 1984; 10: $1043-60$.

Lo JS, Snow SN, Reizner GT. Metastatic basal cell carcinoma: Report of twelve cases ith a review of the literature. J. Am. Acad. Dermatol. 1991; 24: 715-9.

Tavin E, Persky MS, Jacobs J. Metastatic basal cell carcinoma of the head and neck. Laryngoscope 1995; 105: 814-7.

Wade TR, Ackerman AB. The many faces of basal cell carcinoma. J Dermatol Surg Oncol 1978; 4: 778-80.

Rippey JJ. Why classify basal cell carcinomas? Histopathology 1998; 32: 393-8.

Sexton M, Jones DB, Maloney ME. Histologic pattern analysis of basal cell carcinoma. J. Am. Acad. Dermatol. 1990; 23: 1118-26.

1 Miller SJ. Biology of basal cell carcinoma (Part 1). J. Am. Acad. Dermatol. 1991; 24: 1-13.

2 Jacobs GH, Rippey JJ, Altini M. Prediction of aggressive behavior in basal cell carcinoma. Cancer 1982; 49: 533-7.

3 Silverstone $\mathrm{H}$, Gordon D. Regional studies in skin cancer. 2. Wet tropical and subtropical coasts of Queensland. Med J Aust 1966; 2: 733-40.

4 Gallagher RP, Hill GB, Bajdik CD et al. Sunlight exposure, pigmentary factors, and risk of nonmelanocytic skin cancer. I. Basal cell carcinoma. Arch Dermatol 1995; 131: 157-63.

Mithoefer AB, Supran S, Freeman RB. Risk factors associated with the development of skin cancer after liver transplantation. Liver Transpl 2002; 8: 939-44.

6 Corona R, Dogliotti E, D'Errico M et al. Risk factors for basal cell carcinoma in a Mediterranean population: role of recreational sun exposure early in life. Arch Dermatol 2001; 137: 1162-8.

Lear JT. Patients with truncal basal cell carcinoma repesent a high-risk group. Arch Dermatol 1998; 134: 373.

Grossman D, Leffell DJ. The molecular basis of nonmelanoma skin cancer: new understanding. Arch Dermatol 1997; 133: 1263-70.

9 Gallagher RP, Bajdik CD, Fincham S et al. Chemical exposures, medical history and risk of squamous and basal cell carcinoma of the skin. Cancer epidemiology, biomarkers and prevention 1996; 5: 419-24.

Diepgen TL, Mahler V. The epidemiology of skin cancer. Br. J. Dermatol. 2002; 146: $1-6$.

Hartwig A, Groblinghoff UD, Beyersmann D et al. Interaction of arsenic (III) with nucleotide excision repair in UV-irradiated human fibroblasts. Carcinogenesis 1997; 18: 399-405.

2 Lindelof B, Sigurgeirsson B, Tegner E et al. PUVA and cancer: a large-scale epidemiological study. Lancet 1991; 338: 91-3.

3 Barr BBB, McLaren K, Smith IW et al. Human papilloma virus infection and skin cancer in renal allograft recipients. Lancet 1989; 1: 124-9. 
Pfister $\mathrm{H}$, Ter Schegget J. Role of HPV in cutaneous premalignant and malignant tumors. Clin. Dermatol. 1997; 15: 335-47.

Weinstock MA, Coulter S, Bates J et al. Human papillomavirus and widespread cutaneous carcinoma after PUVA photochemotherapy. Arch Dermatol 1995; 131: $701-4$.

Harwood CA, Proby CM. Human papillomaviruses and non-melanoma skin cancer. Curr. Opin. Infect. Dis. 2002; 15: 101-14.

de Hertog SA, Wensveen CA, Bastiaens MT et al. Relation between smoking and skin cancer. J. Clin. Oncol. 2001; 19: 231-8.

28 Boyd AS, Shyr Y, King LE, Jr. Basal cell carcinoma in young women: an evaluation of the association of tanning bed use and smoking. J Am Acad Dermatol 2002; 46: 706-9.

Lear JT, Smith AG, Heagerty AHM et al. Truncal site and detoxifying enzyme polymorphisms significantly reduce time to presentation of further primary cutaneous basal cell carcinoma. Carcinogenesis 1997; 18: 1499-503.

Strange RC, Spiteri MA, Ramachandran S et al. Glutathione S-transferase family of enzymes. Mutat Res 2001; 482: 21-6.

1 Griffiths HR, Mistry P, Herbert KE et al. Molecular and cellular effect of ultraviolet light-induced genotoxicity. Crit. Rev. Clin. Lab. Sci. 1998; 35: 189237.

2 Ketterer B, Meyer DJ. Glutathione S-transferases: a possible role in the detoxification and repair of DNA and lipid hydroperoxides. Mutat Res 1989; 214: 33-40.

3 Hayes JD, Pulford DJ. The glutathione S-transferase supergene family: regulation of GST and the contribution of the enzyme to cancer chemoprotection and drug resistance. Crit. Rev. Biochem. Mol. Biol. 1995; 30: 445-600.

Raza H, Awasthi YC, Zaim MT et al. Glutathione S-transferases in human and rodent skin: multiple forms and species-specific expression. J Invest Dermatol 1991; 96: 463-7.

5 Moscow JA, Townsend AJ, Goldsmith ME et al. Isolation of the human anionic glutathione S-transferase cDNA and the relation of its gene expression to estrogen-receptor content in primary breast cancer. Proc Natl Acad Sci U S A 1988; 85: 6518-22.

Henderson CJ, Smith AG, Ure J et al. Increased skin tumorigenesis in mice lacking pi class glutathione S-transferases. Proc Natl Acad Sci U S A 1998; 95 : 5275-80.

37 Schadendorf D, Jurgovsky K, Kohlmus CM et al. Glutthione and related enzymes in tumor progression and metastases of human melanoma. $J$ Invest Dermatol 1995; 105: 109-12.

38 Hanada $\mathrm{K}$, Ishikawa $\mathrm{H}$, Tamai $\mathrm{K}$ et al. Expression of glutathione S-transferasepi in malignant skin tumors. J Dermatol Sci 1991; 2: 18-23.

39 Pemble S, Schroeder KR, Spencer SR et al. Human glutathione S-transferase theta (GSTT1): cDNA cloning and the characterization of a genetic polymorphism. Biochem. J. 1994; 300: 271-6.

Heagerty AHM, Fitzgerald D, Smith A et al. Glutathione S-transferase GSTM1 phenotypes and protection against cutaneous malignancy. Lancet 1994; 343 : 266-8.

41 Heagerty A, Smith A, English J et al. Susceptibility to multiple cutaneous basal cell carcinomas: significant interaction between glutathione S-transferase GSTM1 genotypes, skin type and male gender. Br J Cancer 1996; 73: 44-8.

Kerb R, Brockmoeller J, Reum T et al. Deficiency of glutathion S-transferases

T1 and M1 as heritable factors of increased cutaneous UV sensitivity. J. Invest. Dermatol. 1997; 108: 229-32. 
43 Lear JT, Heagerty AHM, Smith A et al. Multiple cutaneous basal cell carcinomas: glutathione S-transferase (GSTM1, GSTT1) and cytochrome P450 (CYP2D6, CYP1A1) polymorphisms influence tumor numbers and accrual. Carcinogenesis 1996; 17: 1891-6.

44 Yengi L, Inskip A, Gilford J et al. Polymorphism at the glutathione S-trqnsferase locus GSTM3: Interactions with Cytochrome P450 and glutathione Stransferase genotypes as risk factors for multiple cutaneous basal cell carcinoma. Canc. Res. 1996; 56: 1974-7.

45 Ramachandran S, Fryer AA, Smith AG et al. Basal cell carcinomas: association of allelic variants with a high-risk subgroup of patients with the multiple presentation phenotype. Pharmacogenetics 2001; 11: 247-54.

Ramachandran S, Lear JT, Ramsay $\mathrm{H}$ et al. Presentation with multiple cutaneous basal cell carcinomas: Association of glutathione S-transferase and cytochrome P450 genotypes with clinical phenotype. Canc. Epid. Biomark. Prev. 1999; 8: 61-7.

47 Ramachandran S, Hoban PR, Ichii-Jones F et al. Glutathione S-transferase GSTP1 and cyclin D1 genotypes: association with numbers of basal cell carcinomas in a patient subgroup at high risk of multiple tumors. Pharmacogenetics 2000; 10: 545-56.

48 Milstone EB, Helwig EB. Basal cell carcinoma in children. Arch Dermatol 1973; 108: $523-7$.

49 Cleaver JE. Defective repair replication of DNA in Xeroderma Pigmentosum. Nature 1968; 218: 652-6.

50 Sarasin A. The molecular pathways of ultraviolet-induced carcinogenesis. Mutat Res 1999; 428: 5-10.

51 Cleaver JE, Crowley E. UV damage, DNA repair and skin carcinogenesis. Front Biosci 2002; 7: d1024-43.

52 Hoeijmakers $\mathrm{JH}$. Genome maintenance mechanisms for preventing cancer. Nature $2001 ;$ 411: 366-74.

53 Kitao S, Shimamoto A, Goto M et al. Mutations in RECQL4 cause a subset of cases of Rothmund-Thomson syndrome. Nat Genet 1999; 22: 82-4.

54 Yu CE, Oshima J, Fu YH et al. Positional cloning of the Werner's syndrome gene. Science 1996; 272: 193-4.

55 Wang LL, Levy ML, Lewis RA et al. Clinical manifestations in a cohort of 41 Rothmund-Thomson syndrome patients. Am J Med Genet 2001; 102: 11-7.

56 Gorlin RJ. Nevoid basal cell carcinoma syndrome. Dermatol Clin 1995; 13: $113-$ 25.

57 Harris CC. Molecular epidemiology of basal cell carcinoma. J. Natl. Cancer Inst. 1996; 88: 315-7.

58 Hahn $\mathrm{H}$, Wicking $\mathrm{C}$, Zaphiropoulous PG et al. Mutation of the human homolog of Drosophila patched in the nevoid basal cell carcinoma syndrome. Cell 1996; 85: 841-51.

59 Johnson RL, Rothman AL, Xie J et al. Human homolog of patched, a candidate gene for the basal cell nevus syndrome. Science 1996; 272: 1668-71.

60 Wicking C, McGlinn E. The role of hedgehog signalling in tumorigenesis. Cancer Lett. 2001; 173: 1-7.

61 Kim M-Y, Park HJ, Baek S-C et al. Mutations of the p53 and PTCH gene in basal cell carcinomas: UV mutation signature and strand bias. J. Dermatol. Sci. 2002; 29: 1-9.

62 Bodak N, Queille S, Avril MF et al. High levels of patched gene mutations in basal cell carcinomas from patients with xeroderma pigmentosum. Proc. Natl. Acad. Sci. USA 1999; 96: 5117-22.

63 Bale AE, Yu K-P. The hedgehog pathway and basal cell carcinomas. Hum Mol Genet 2001; 10: 757-62. 
Wicking C, Smyth I, Bale A. The hedgehog signalling pathway in tumorigenesis and development. Oncogene 1999; 18: 7844-51.

Echelard Y, Epstein DJ, St-Jacques B et al. Sonic hedgehog, a member of a family of putative signaling molecules, is implicated in the regulation of CNS polarity. Cell 1993; 75: 1417-30.

Johnson RL, Laufer E, Riddle RD et al. Ectopic expression of Sonic hedgehog alters dorsal-ventral patterning of somites. Cell 1994; 79: 1165-73.

Riddle RD, Johnson RL, Laufer E et al. Sonic hedgehog mediates the polarizing activity of the ZPA. Cell 1993; 75: 1401-16.

Chiang $\mathrm{C}$, Litingtung $\mathrm{Y}$, Lee $\mathrm{E}$ et al. Cyclopia and defective axial patterning in mice lacking sonic hedgehog gene function. Nature 1996; 383: 407-13.

Stone DM, Hynes M, Armanini M et al. The tumor-suppressor gene patched encodes a candidate receptor for Sonic hedgehog. Nature 1996; 384: 129-34.

Lam CW, Xie J, To KF et al. A frequent activated smoothened mutation in sporadic basal cell carcinomas. Oncogene 1999; 18: 833-6.

Aszterbaum M, Epstein J, Oro A et al. Ultraviolet and ionizing radiation enhance the growth of BCCs and trichoblastomas in patched heterozygous knockout mice. Nat Med 1999; 5: 1285-91.

Xie J, Murone M, Luoh SM et al. Activating Smoothened mutations in sporadic basal cell carcinomas. Nature 1998; 391: 90-2.

(1)

Daya-Grosjean L, Sarasin A. UV-specific mutations of the human patched gene in basal cell carcinomas from normal individuals and xeroderma pigmentosum patients. Mut. Res. 2000; 450: 193-9.

Gailani MR, Stahle-Backdahl M, Leffell DJ et al. The role of the human homologue of Drosophila patched in sporadic basal cell carcinoma. Nat. Genet. 1996; 14: 78-81.

Zaphiropoulos PG, Unden AB, Rahnama $F$ et al. PTCH2, a novel human patched gene, undergoing alternative splicing and up-regulate in basal cell carcinoma. Cancer Res. 1999; 59: 787-92.

Smyth I, Narang MA, Evans T et al. Isolation and characterization of human Pathed 2 (PTCH2), a putative tumor suppressor gene in basal cell carcinoma and medulloblatoma on chromosome 1p32. Hum. Mol. Genet. 1999; 8: 291-7.

Michaelsson G, Olsson E, Westermark P. The Rombo syndrome: a familial disorder with vermiculate atrophoderma, milia, hypotrichosis, trichoepitheliomas, basal cell carcinomas and peripheral vasodilation with cyanosis. Acta Derm Venereol (Stockh) 1981; 61: 497-503. van Steensel MA, Jaspers NG, Steijlen PM. A case of Rombo syndrome. Br J Dermatol 2001; 144: 1215-8.

Kastan MB, Onkyekwere O, Sidransky D et al. Participation of p53 protein in the cellular response to DNA damage. Cancer Res. 1991; 51: 6304-11.

Hollstein M, Sidransky D, Vogelstein B et al. p53 mutations in human cancers. Science 1991; 253: 49-53.

Siliciano JD, Canman CE, Taya $Y$ et al. DNA damage induces phosphorylation of the amino terminus of p53. Genes Dev. 1997; 11: 3471-81.

Caspari T. How to activate p53. Curr Biol 2000; 10: 315-7.

Kubbutat MHG, Jones SN, Vousden KH. Regulation of p53 stability by Mdm2. Nature 1997; 387: 299-303.

Haupt Y, Maya R, Kazaz AN et al. Mdm2 promotes the rapid degradation of p53. Nature 1997; 387: 296-9.

Unger T, Juven-Gershon T, Moallem E et al. Critical role for Ser20 of human p53 in the negative regulation of p53 by Mdm2. EMBO J 1999; 18: 1805-14.

Vogt Sionov RV, Haupt $Y$. The cellular response to $p 53$ : the decision between life and death. Oncogene 1999; 18: 6145-57. 
87 Ronen D, Schwartz D, Teitz $Y$ et al. Induction of HL-60 cells to undergo apoptosis is determined by high levels of wild-type p53 protein whereas differentiation of the cells is mediated by lower p53 levels. Cell Growth Different 1996; 7: 21-30.

88 Miyashita T, Reed JC. Tumor suppressor p53 is a direct transcriptional activator of the human bax gene. Cell 1995; 80: 293-9.

89 Merchant AK, Loney TL, Maybaum J. Expression of wild-type p53 stimulates an increase in both bax and bcl-xl protein content in HT-29 cells. Oncogene 1996; 13: $2631-7$.

90 Hall PA, McKee PH, Dover R et al. High levels of p53 protein in UV-irradiated normal human skin. Oncogene 1993; 8: 203-7.

91 Auepemkiate S, Boonyaphiphat P, Thongsuksai P. P53 expression related to the aggressive infiltrative histopathological feature of basal cell carcinoma. Histopathology 2002; 40: 568-73.

92 Demirkan NC, Colakoglu N, Duzcan E. Value of p53 protein in biological behavior of basal cell carcinoma and in normal epithelia adjacent to carcinomas. Pathol Oncol Res 2000; 6: 272-4.

93 Rosenstein BS, Phelps RG, Weinstock MA et al. P53 mutations in basal cell carcinomas arising in routine users of sunscreen. Photochem Photobiol 1999; 70: 798-806.

94 Ziegler A, Leffell DJ, Kunala S et al. Mutation hotspots due to sunlight in the p53 gene of nonmelanoma skin cancers. Proc. Natl. Acad. Sci. USA 1993; 90 : 4216-20.

95 Knudson AGJ. Heridetary cancer, oncogenes and antioncogenes. Cancer Res 1985; 45: 1437-43.

96 Wikonkal NM, Brash DE. Ultraviolet radiation induced signature mutations in photocarcinogenesis. J. Invest. Dermatol. Symp. Proc. 1999; 4: 6-10.

97 Sturm RA. Skin colour and skin cancer-MC1R, the genetic link. Melanoma Res 2002; 12: 405-16.

98 Bastiaens MT, ter Huurne JA, Kielich C et al. Melanocortin-1 receptor gene variants determine the risk of nonmelanoma skin cancer independently of fair skin and red hair. Am J Hum Genet 2001; 68: 884-94.

99 Box NF, Duffy DL, Irving RE et al. Melanocortin-1 receptor genotype is a risk factor for basal and squamous cell carcinoma. J Invest Dermatol 2001; 116: 224-9.

100 Parsa R, Yang A, McKeon F et al. Association of p63 with proliferative potential in normal and neoplastic human keratinocytes. J. Invest. Dermatol. 1999; 113: 1099-105.

101 Wang TY, Chen BF, Yang YC et al. Histologic and immunophenotypic classification of cervical carcinomas by expression of the p53 homologue p63: a study of 250 cases. Hum Pathol 2001; 32: 479-86.

102 Quade BJ, Yang A, Wang $Y$ et al. Expression of the p53 homologue p63 in early cervical neoplasia. Gynecol Oncol 2001; 80: 24-9.

103 Di Como CJ, Urist MJ, Babayan I et al. p63 expression profiles in human normal and tumor tissues. Clin Cancer Res 2002; 8: 494-501.

104 Mills AA, Zheng B, Wang XJ et al. P63 is a p53 homologue required for limb and epidermal morphogenesis. Nature 1999; 398: 708-13.

105 Osada M, Ohba C, Kawahara C et al. Cloning and functional analysis of human p51, which structurally and functionally resembles p53. Nat Med 1998; 4: 83943.

106 Little NA, Jochemsen AG. Molecules in focus: p63. Int J Biochem Cell Biol 2002; 34: 6-9.

107 Pellegrini G, Dellambra E, Golisano O et al. P63 identifies keratinocyte stem cells. Proc Natl Acad Sci U S A 2001; 98: 3156-61. 
Koster MI, Huntzinger KA, Roop DR. Epidermal differentiation: transgenic/knockout mouse models reveal genes involved in stem cell fate decisions and commitment to differentiation. J Investig Dermatol Symp Proc 2002; 7: 41-5.

Dellavalle RP, Walsh P, Marchbank A et al. CUSP/p63 expression in basal cell carcinoma. Exp. Dermatol. 2002; 11: 203-8.

110 Liefer KM, Koster MI, Wang XJ et al. Down-regulation of p63 is required for epidermal UV-B-induced apoptosis. Cancer Res. 2000; 60: 4016-20.

111 Penn I. Effect of immunosuppression on pre-exisitng cancers. Transplantation 1993; 55: 742-7.

112 Espana A, Redondo P, Fernandez AL et al. Skin cancer in heart transplant recipients. J Am Acad Dermatol 1995; 32: 458-65.

113 Ferrandiz C, Fuente MJ, Ribera M et al. Epidermal dysplasia and neoplasia in kidney transplant recipients. J Am Acad Dermatol 1995; 33: 590-6.

114 Otley CC, Pittelkow MR. Skin cancer in liver transplant recipients. Liver Transpl 2000; 6: 253-62.

115 Ondrus D, Pribylincova V. Breza $\mathrm{J}$ et al. The incidence of tumors in renal transplant recipients with long-term immunosuppressive therapy. Int Urol Nephrol 1999; 31: 417-22.

116 Barrett WI, First MR, Aron BS et al. Clinical course of malignancies in renal transplant recipients. Cancer 1993; 72: 2186.

117 Ong CS, Keogh AM, Kossard S et al. Skin cancer in Australian heart transplant recipients. J Am Acad Dermatol 1999; 40: 27-34.

118 Hartevelt MM, Bouwes Bavinck JN, Kootte AMM et al. Incidence of skin cancer after renal transplantation in The Netherlands. Transplantation 1990; 49: 506-9.

119 Euvrard S, Kanitakis J, Pouteil-Noble C et al. Comparative epidemiologic study of premalignant and malignant epithelial cutaneous lesions developing after kidney and heart transplantation. J Am Acad Dermatol 1995; 33: 222-9.

120 Franceschi S, Dal Maso L, Arniani S et al. Risk of cancer other than Kaposi's sarcoma and non-Hodgkin's lymphoma in persons with AIDS in Italy. Cancer and AIDS Registry Linkage Study. Br J Cancer 1998; 78: 966-70.

121 Lobo DV, Chu P, Grekin RC et al. Nonmelanoma skin cancers and infection with the human immunodeficiency virus. Arch. Dermatol. 1992; 128: 623-7.

122 Benacerrae B. Role of MHC gene products in immune regulation. Science 1981; 212: 1229.

123 Dausset J, Colombani J, Hors J. Major histocompatibility complex and cancer, with special reference to human familiar tumors (Hodgkin's disease and other malignancies). Cancer Surv. 1982; 1.

124 Ruiter DJ, Bergman W. Welvaart $\mathrm{K}$ et al. Immunohistochemical analysis of malignant melanomas and nevocellular nevi with monoclonal antibodies to distinct monomorphic determinants of HLA-antigens. Cancer Res. 1984; 44: 3930-4.

125 Myskowsky PL, Safai B, Good RA. Decreased lymphocyte blastogenic response in patients with multiple basal cell carcinomas. J. Am. Acad. Dermatol. 1981; 4: 711-4.

126 Cabrera T, Garrido V, Concha A et al. HLA molecules in basal cell carcinoma of the skin. Immunobiol. 1992; 185: 440-52.

127 Garcia-Plata D, Mozos E, Sierra MA et al. HLA expression in basal cell carcinomas. Inv. Met. 1991; 11: 166-73.

128 Bouwes Bavinck JN, Bastiaens MT, Marugg ME et al. Further evidence for an association of HLA-DR7 with basal cell carcinoma on the tropical island of Saba. Arch Dermatol 2000; 136: 1019-22.

129 Rompel R, Petres J, Kaupert $\mathrm{K}$ et al. HLA phenotype and multiple basal cell carcinomas. Dermatology 1994; 189: 222-4. 
130 Rompel R, Petres J, Kaupert $\mathrm{K}$ et al. Human leukocyte antigens and multiple basal cell carinomas. Rec. Res. Canc. Res. 1995; 139: 297-302.

131 Czarnecki D, Lewis A, Nicholson I et al. HLA-DR1 is not a sign of poor prognosis for the development of multiple basal cell carcinomas. J. Am. Acad. Dermatol. 1992; 26: 717-9.

132 Bouwes Bavinck JN, Kootte AMM, Van der Woude FJ et al. HLA-A11associated resistance to skin cancer in renal transplant recipients. $N$. Engl. J. Med. 1990; 323.

133 Bouwes Bavinck JN, Claas FHJ, Hardie DR et al. Relation between HLA antigens and skin cancer in renal transplant recipients in Queensland, Australia. J. Invest. Dermatol. 1997; 108: 708-11.

134 Galloway DA, McDougall JK. Human papillomaviruses and carcinomas. Adv Virus Res 1989; 37: 125-71.

135 Shamanin V, Zur Hausen $\mathrm{H}$, Lavergne D et al. Human papillomavirus infections in nonmelanoma skin cancers from renal transplant recipients and nonimmunosuppressed patients. J Nat/ Cancer Inst 1996; 88: 802-11.

136 Zackheim HS. Origin of the human basal cell epithelioma. J. Invest. Dermatol. 1963; 40: 283.

137 Krueger K, Blume-Peytavi U, Orfanos CE. Basal cell carcinoma possibly originates from the outer root sheath and/or the bulge region of the vellus hair follicle. Arch. Dermatol. Res. 1999; 291: 253-9.

138 Lacour JP. Carcinogens of basal cell carcinomas: genetics and molecular mechanisms. Br. J. Dermatol. 2002; 146: 17-9.

139 Miller SJ, Sun TT, Lavker RM. Hair follicles, stem cells and skin cancer. J. Invest. Dermatol. 1993; 100: 288S-94S.

140 Brash DE, Rudolph JA, Simon JA et al. A role for sunlight in skin cancer: UVinduced p53 mutations in squamous cell carcinoma. Proc. Natl. Acad. Sci. USA 1991; 88: 10124-8.

141 Taylor G, Lehrer MS, Jensen PJ et al. Involvement of follicular stem cells in forming not only the follicle but also the epidermis. Cell 2000; 102: 451-61.

142 Cotsarelis G, Sun T-T, Lavker RM. Label-retaining cells reside in the bulge of the pilosebaceous unit: implications for follicular stem cells, hair cycle and skin carcinogenesis. Cell 1990; 61: 1329.

143 Zackheim HS. Comparative cutaneous carcinogenesis in the rat. Differential response to the application of anthracene, methylcholanthrene and dimethylbenzanthracene. Oncology 1964; 17: 236.

144 Kore-eda S, Horiguchi $\mathrm{Y}$, Ueda M et al. Basal cell carcinoma cells resemble follicular matrix cells rather than follicular bulge cells: immunohistochemical and ultrastructural comparative studies. Am. J. Dermatopathol. 1998; 20: 362-9.

145 Walsh N. Ackerman AB. Infundibulocystic basal cell carcinoma: a newly described variant. Modem Pathol 1990; 3: 599-608.

146 Asada M, Schaart F-M, De Almeida HL et al. Solid basal cell epithelioma (BCE) possibly originates from the outer root sheath of the hair follicle. Acta Derm Venereol (Stockh) 1993; 73: 286-92.

147 Miller SJ, Wei Z-G, Wilson C et al. Mouse skin is particularly susceptible to tumor initiation during early anagen of the hair cycle: possible involvement of air follicle stem cells. J. Invest. Dermatol. 1993; 101: 591.

148 Bernemann T-M, Podda M, Wolter M et al. Expression of the basal cell adhesion molecule (B-CAM) in normal and diseased human skin. J. Cutan. Pathol. 2000; 27: 108-11.

149 Kanitakis J, Bourchany D, Faure $M$ et al. Expression of the hair stem cellspecific keratin 15 in pilar tumors of the skin. Eur. J. Dermatol. 1999; 9: 363-5.

150 Howell JB, Mehregan AH. Pursuit of the pits in the nevoid basal cell carcinoma syndrome. Arch Dermatol 1970; 102: 586-97. 
Baserga R. The biology of cell reproduction. 1985.

Tsao H. Genetics of nonmelanoma skin cancer. Arch. Dermatol. 2001; 137: 1486-92.

Hockenbery D, Nunez G, Milliman C et al. Bcl-2 is an inner mitochondrial membrane protein that blocks programmed cell death. Nature $1990 ; 348$ : 334-6. Hunter T. Cooperation between oncogenes. Cell 1991; 64: 249-70.

Anderson E, Howell T. Breast cancer: oncogenes and suppressor genes. Ann Oncol 1990; 1: 242-3.

Varmus HE. The molecular genetics of cellular oncogenes. Annu Rev Genet 1984; 18: 553-612.

Suarez HG. Activated oncogenes in human tumors. Anticancer Res 1989; 9; 1331-43.

Chen YC, Chen PJ, Yeh SH et al. Deletion of the human retinoblastoma gene in primary leukemias. Blood 1990; 76: 2060-4.

Klein G. Genes that can antagonize tumor development. Faseb J 1993; 7: 8215.

Marshall CJ. Tumor suppressor genes. Cell 1991; 64: 313-26.

Vogelstein B, Kinzler KW. The multistep nature of cancer. Trends Genet 1993; 9: 138-41.

Rees JL, Healy E. Molecular genetic approaches to non-melanoma and melanoma skin cancer. Clin. Exp. Dermatol. 1996; 21: 253-62.

Abdelsayed RA, Guijarro-Rojas M, Ibrahim NA et al. Immunohistochemical evaluation of basal cell carcinoma and trichepithelioma using Bcl-2, Ki67, PCNA and P53. J Cutan Pathol 2000; 27: 169-75.

Baum H-P. Meurer I, Unteregger G. Ki-67 antigen expression and growth pattern of basal cell carcinomas. Arch Dermatol Res 1993; 285: 291-5.

Horlock NM, Wilson GD, Daley FM et al. Cellular proliferation characteristics of basal cell carcinoma: relationship to clinical subtype and histopathology. Eur $J$ Surg Oncol 1997; 23: 247-52.

Naeyaert JM, Pauwels C, Geerts ML et al. CD-34 and Ki-67 staining patterns of basaloid follicular hamartoma are different from those in fibroepithelioma of Pinkus and other variants of basal cell carcinoma. J Cutan Pathol 2001; 28 : 538-41.

Chang $\mathrm{CH}$, Tsai RK, Chen GS et al. Expression of bcl-2, p53 and $\mathrm{Ki}-67$ in arsenical skin cancers. J Cutan Pathol 1998; 25: 457-62.

Tilli CMLJ, Stavast-Kooy AJW, Ramaekers FCS et al. Bax expression and growth behavior of basal cell carcinomas. J. Cutan. Pathol. 2002; 29: 79-87.

Kazantseva IA, Khlebnikova AN, Babaev VR. Immunohistochemical study of primary and recurrent basal cell and metatypical carcinomas of the skin. Am J Dermatopathol 1996; 18: 35-42.

Toth DP, Guenther LC, Shum DT. Proliferating cell nuclear antigen (PCNA); prognostic value in the clinical recurrence of primary basal cell carcinoma. $J$ Dermatol Sci 1996; 11: 36-40.

Grimwood RE, Ferris CF, Mercill DB et al. Proliferating cells of human basal cell carcinoma are located on the periphery of tumor nodules. J. Invest. Dermatol. 1986; 86: 191-4.

Coates PJ, Hobbs RC, Crocker $\mathrm{J}$ et al. Identification of the antigen recognized by the monoclonal antibody BU31 as lamins A and C. J Pathol 1996; 178: 21-9.

Lin F, Worman HJ. Structural organization of the human gene encoding nuclear lamin A and nuclear lamin C. J. Biol. Chem. 1993; 268: 16321-6.

Machiels BM, Zorenc AHG, Endert JM et al. An alternative splicing product of the lamin A/C gene lacks exon 10. J. Biol. Chem. 1996; 271: 9249-53.

Replogle-Schwab R, Pienta KJ, Getzenberg RH. The utilization of nuclear matrix proteins for cancer diagnosis. Crit. Rev. Euk. Gene Exp. 1996; 6: 103-13. 
176 Roeber RA, Weber K, Osborn M. Differential timing of nuclear lamin A/C expression in the various organs of the mouse embryo and the young animal: a developmental study. Development 1989; 105: 365-78.

177 Venables RS, McLean S, Luny D et al. Expression of individual lamins in basal cell carcinomas of the skin. Br. J. Cancer 2001; 84: 512-9.

178 Broers JLV, Machiels BM, Kuijpers HJH et al. A- and B-type lamins are differentially expressed in normal human tissues. Histochem. Cell Biol. 1997; 107: 505-17.

179 Oguchi M, Sagara J, Matsumoto K et al. Expression of lamins depends on epidermal differentiation and transformation. Br J Dermatol 2002; 147: 853-8.

180 Tilli CM, Ramaekers FC, Broers JL et al. Lamin expression in normal human skin, actinic keratosis, squamous cell carcinoma and basal cell carcinoma. $\mathrm{Br} J$ Dermatol 2003; 148: 102-9.

181 Heenen M. Achten G, Galand P. Autoradiographic analysis of cell kinetics in human normal epidermis and basal cell carcinoma. Cancer Res. 1973; 33: 1237.

182 Kerr JF, Wyllie AH, Currie AR. Apoptosis: a basic biological phenomenon with wide-ranging implications in tissue kinetics. Br J Cancer 1972; 26: 239-57.

183 Mooney EE, Ruis Peris JM, O'Neill A et al. Apoptotic and mitotic indexes in malignant melanoma and basal cell carcinoma. J. Clin. Pathol. 1995; 48: 242-4.

184 Wyllie AH, Kerr JFR, Currie AR. Cell death: the significance of apoptosis. Int. Rev. Cytol. 1980; 68: 251-306.

185 Raff MC, Durand B, Gao FB. Cell number control and timing in animal development: the oligodendrocyte cell lineage. Int J Dev Biol 1998; 42: 263-7.

186 McDonnell TJ, Marin MC, Hsu B et al. The bcl-2 oncogene: Apoptosis and neoplasia. Radiat. Res. 1993; 136: 307-12.

187 Majno G, Joris I. Apoptosis, oncosis and necrosis. An overview of cell death. Am. J. Pathol. 1995; 146: 3-15.

188 Zimmermann KC, Bonzon C, Green DR. The machinery of programmed cell death. Pharmacol Ther 2001; 92: 57-70.

189 Peter ME, Krammer PH. Mechaism of CD95 (APO-1/Fas)-mediated apoptosis. Curr Opin Immunol 1998; 10: 545-51.

190 Suda T, Takahashi T, Golstein P et al. Molecular cloning and expression of the Fas ligand, a novel member of the tumor necrosis factor family. Cell 1993; 75: 1169-78.

191 Nagata S, Golstein P. The Fas death factor. Science 1995; 267: 1449-56.

192 Cory S. Regulation of lymphocyte survival by the bcl-2 gene family. Annu. Rev. Immunol. 1995; 13: 513-43.

193 Gross A, McDonnell TJ, Korsmeyer SJ. Bcl-2 family members and the mitochondria in apoptosis. Genes \& Dev. 1999; 13: 1899-911.

194 Tsujimoto Y, Finger LR, Yunis J et al. Cloning of the chromosome breakpoint of neoplastic B cells with the $\mathrm{t}(14: 18)$ chromosome translocation. Science 1984; 226: $1097-9$.

195 Cleary ML, Smith SD, Sklar J. Cloning and structural analysis of CDNAs for Bcl2 and a hybrid bcl-2/immunoglobulin transcript resulting from the $t(14: 18)$ translocation. Cell 1986; 47: 19-28.

196 Boise LH, Gonzalez-Garcia M, Postema CE et al. Bcl-x, a bcl-2-related gene that functions as a dominant regulator of apoptotic cell death. Cell 1993; 74: 597-608.

197 Korsmeyer SJ. Bcl-2 initiates a new category of oncogenes:regulators of cell death. Blood 1992; 80: 879-86.

198 Chiou SK, Rao L, White E. Bcl-2 blocks p53-dependent apoptosis. Mol Cell Biol $1994 ; 14: 2556-63$. 
199 Alnemri ES, Fernandes TF, Haldar S et al. Involvement of BCL-2 in glucocorticoid-induced apoptosis of human pre-B-leukemias. Cancer Res 1992; 52: 491-5.

200 Bissonnette RP, Echeverri F, Mahboubi A et al. Apoptotic cell death induced by c-myc is inhibited by bcl-2. Nature 1992; 359: 552-4.

201 Krajewski S, Tanaka S, Takayama S et al. Ilnvestigation of the subcellular distribution of the bcl-2 oncoprotein: residence in the nuclear envelope, endoplasmic reticulum, and outer mitochondrial membranes. Cancer Res 1993; 53: 4701-14.

202 Ito T, Deng X, Carr B. Bcl-2 phosphorylation required for anti-apoptosis function. J. Biol. Chem. 1997; 272: 11671-3.

203 Adams JA, Cory S. The Bcl-2 protein family: Arbiters of cell survival. Science 1998; 281: $1322-5$.

204 Reed JC, Zha H, Aime-Sempe C et al. Structure-function analysis of Bcl-2 family proteins. Regulators of programmed cell death. Adv Exp Med Biol 1996; 406: 99-112.

205 Sato T, Hanada M, Bodrug S et al. Interactions among members of the Bcl-2 protein family analyzed with a yeast two-hybrid system. Proc. Natl. Acad. Sci. USA 1994; 91: 9238-42.

206 Oltvai ZN, Milliman CL, Korsmeyer SJ. Bcl-2 heterodimerizes in vivo with a conserved homolog. Bax, that accelerates programmed cell death. Cell 1993; 74: 609-19.

207 Alnemri ES, Livingstone DJ, Nicholson DW et al. Human ICE/CED-3 protease nomenclature. Cell 1996; 87: 171.

208 Nicholson DW, Thornberry NA. Caspases: killer proteases. Trends Biochem Sci 1997; 22: 299-306.

209 Van de Craen M, Van Loo G, Pype S et al. Identification of a new caspase homologue: caspase-14. Cell Death DIffer 1998; 5: 838-46.

210 Stennicke HR, Salvesen GS. Properties of the caspases. Biochim Biophys Acta 1998; 1387: 17-31.

211 Enari M. Sakahira H, Yokomaya $\mathrm{H}$ et al. A caspase-activated DNAse that degrades DNA during apoptosis, and its inhibitor CAD. Nature 1998; 391: 4350.

212 Liu X, Zou H, Slaughter $\mathrm{C}$ et al. DFF, a heterodimeric protein that functions downstream of caspase- 3 to trigger DNA fragmentation during apoptosis. Cell 1997; 89: 175-84.

213 Takahashi A, Alnemri ES, Lazebnik YA et al. Cleavage of lamin A by Mch2alpha but not CPP32: multiple interleukin 1beta-converting enzymerelated proteases with distinct substrate recognition properties are active in apoptosis. Proc Natl Acad Sci U S A 1996; 93: 8395-400.

214 Orth K, Chinnaiyan AM, Garg M et al. The CED-3/ICE-like protease Mch2 is activated during apoptosis and and cleaves the death substrate lamin A. J Biol Chem 1996; 271: 16443-6.

$215 \mathrm{Ku}$ NO, Omary MB. Effect of mutation and phosphorylation of type I keratins on their caspase-mediated degradation. J Biol Chem 2001; 276: 26792-8.

216 Martin SJ, Finucane DM, Amarante-Mendes GP et al. Phosphatidylserine externalization during CD-95-induced apoptosis of cells and cytoplasts requires ICE/CED-3 protease activity. J Biol Chem 1996; 271: 28753-6.

217 Casiano CA, Martin SJ, Green DR et al. Selective cleavage of nuclear autoantigens during CD95 (Fas/APO-1)-mediated T cell apoptosis. J Exp Med 1996; $184: 765-70$.

218 Deveraux QL, Takahashi R, Salvesen GS et al. X-linked IAP is a direct inhibitor of cell-death proteases. Nature 1997; 388: 300-4. 
219 Roy N, Deveraux QL, Takahashi R et al. The c-IAP-1 and C-IAP-2 proteins are direct inhibitors of specific caspases. EMBO J 1997; 16: 6914-25.

220 Polakowska RR, Piacentini M, Bartlett R et al. Apoptosis in human skin development: morphogenesis, periderm, and stem cells. Dev Dyn 1994; 199: 176-88.

221 Weil M, Raff MC, Braga VM. Caspase activation in the terminal differentiation of human epidermal keratinocytes. Curr Biol 1999; 9: 361-4.

222 Tyrrell RM. UV activation of mammalian stress proteins. Exs 1996; 77: 255-71.

223 Wikonkal NM, Berg RJW, van Haselen $\mathrm{CW}$ et al. Bcl-2 versus p53 protein expression and apoptotic rate in human nonmelanoma skin cancers. Arch. Dermatol 1997; 133: 599-602.

224 Bolshakov S, Walker CM, Strom SS et al. p53 mutations in human aggressive and nonaggressive basal and squamous cell carcinomas. Clin Cancer Res 2003; 9: 228-34.

225 Staibano S, Lo Muzio L, Pannone $\mathrm{G}$ et al. Interaction between bcl-2 and P53 in neoplastic progression of basal cell carcinoma of the head and neck. Anticancer Res 2001: 21: 3757-64.

226 Delehedde $\mathrm{M}$, Cho $\mathrm{SH}$, Sarkiss $\mathrm{M}$ et al. Altered expression of bcl-2 family member proteins in nonmelanoma skin cancer. Cancer 1999; 85: 1514-22.

227 Cerroni L, Kerl H. Aberrant bcl-2 protein expression provides a possible mechanism of neoplastic cell growth in cutaneous basal cell carcinoma. J. Cutan. Pathol. 1994; 21: 398-403.

228 Verhaegh MEJM, Sanders CJG, Arends JW et al. Expression of the apoptosissuppressing protein bcl-2 in non-melanoma skin cancer. Br. J. Dermatol. 1995; 132: $740-4$.

229 Rodriguez-Villanueva J, Colome MI, Brisbay S et al. The expression and localization of bcl-2 protein in normal skin and in non-melanoma skin cancers. Path. Res. Pract. 1995; 191: 391-8.

230 Morales-Ducret JCR, Van de Rijn M, LeBrun DP et al. Bcl-2 expression in primary malignancies of the skin. Arch. Dermatol. 1995; 131: 909-12.

231 Grossman D. McNiff JM, Li F et al. Expression of the apoptosis inhibitor, survivin, in nonmelanoma skin cancer and gene targeting in a keratinocyte cell line. Lab. Invest. 1999; 79: 1121-6.

232 Hill LL, Ouhtit A, Loughlin SM et al. Fas ligand: a sensor for DNA damage critical in skin cancer etiology. Science 1999; $285: 898-900$.

233 Filipowicz E, Adegboyega P. Sanchez RL et al. Expression of CD95 (fas) in sun-exposed human skin and cutaneous carcinomas. Cancer 2002; 94: 814-9.

234 Gutierrez-Steil C, Wrone-Smith T. Sun X et al. Sunlight-induced basal cell carcinoma tumor cells and ultraviolet-B-irradiated psoriatic plaques express Fas ligand (CD95L). J. Clin. Invest. 1998; 101: 33-9.

235 Albright SD, 3rd. Treatment of skin cancer using multiple modalities. J Am Acad Dermatol 1982; 7: 143-71.

236 Telfer NR, Colver GB, Bowers PW. Guidelines for the management of basal cell carcinomas. Br. J. Dermatol. 1999; 141: 415-23.

237 Thissen MRTM, Schroeter CA, Neumann HAM. Effective photodynamic therapy with 5-aminolevulinic acid for nodular basal cell carcinomas using a preceding debulking technique. Br. J. Dermatol. 2000; 142: 338-9.

238 Miller BH. Shavin JS, Cognetta A et al. Nonsurgical treatment of basal cell carcinomas with intralesional 5-fluorouracil/epinephrine injectable gel. J Am Acad Dermatol 1997: 36: $72-7$.

239 Fisher DE. Apoptosis in cancer therapy: Crossing the treshold. Cell 1994; 78: 539-42. 
Jee $\mathrm{SH}$, Shen SC, Chiu HC et al. Overexpression of interleukin-6 in human basal cell carcinoma cell lines increases anti-apoptoticactivity and tumorigenic potency. Oncogene 2001; 20: 198-208.

241 Jee $\mathrm{SH}$, Shen SC, Tseng CR et al. Curcumin induces a p53-independent apoptosis in human basal cell carcinoma cells. J Invest Dermatol 1998; 111 : 656-61.

242 Huang Z. Bcl-2 family proteins as targets for anticancer drug design. Oncogene 2000; 19: 6627-31.

243 Rodriguez-Villanueva J, McDonnell TJ. Induction of apoptotic cell death in nonmelanoma skin cancer by interferon-alpha. Int J Cancer 1995; 61: 110-4.

244 Buechner SA, Wernli M, Harr T et al. Regression of basal cell carcinoma by intralesional interferon-alpha treatment is mediated by CD95 (APO-1/FAS)CD95 ligand-induced suicide. J. Clin. Invest. 1997; 100: 2691-6.

245 Romagosa R, Saap L, Givens M et al. A pilot study to evaluate the treatment of basal cell carcinoma with 5-fluorouracil using phosphatidyl choline as a transepidermal carrier. Dermatol Surg 2000; 26: 338-40.

246 Brash DE, Ponten J. Skin precancer. Cancer Surveys 1998; 32: 69-113.

247 Nakaseko H, Kobayashi M, Akita Y et al. Histological changes and involvement of apoptosis after photodynamic therapy for actinic keratoses. $\mathrm{Br} J$ Dermatol 2003; 148: 122-7.

248 Kalka K, Merk H, Mukhtar H. Photodynamic therapy in dermatology. J Am Acad Dermatol 2000; 42: 389-413.

249 Lotan R. Retinoids in cancer prevention. Faseb J 1996; 10: 1031-9.

250 Hoffman EJ. Cancer and the search for selective biochemical inhibitors. 1999.

251 Levin C, Maibach H. Exploration of "alternative" and "natural" drugs in dermatology. Arch Dermatol 2002; 138: 207-11.

252 Elmets CA, Singh D, Tubesing $\mathrm{K}$ et al. Cutaneous photoprotection from ultraviolet injury by green tea polyphenols. J Am Acad Dermatol 2001; 44: 42532.

253 Zhao J, Jin X, Yaping $E$ et al. Photoprotective effects of black tea extracts against UVB-induced phototoxicity in skin. Photochem Photobiol 1999; 70: 63744.

254 Lu YP, Lou YR, Xie JG et al. Inhibitory effect of black tea on the growth of established skin tumors in mice: effects on tumor size, apoptosis, mitosis and bromodeoxyuridine incorporation into DNA. Carcinogenesis 1997; 18: 2163-9.

255 Apitz-Castro R, Ledezma E, Escalante $\mathrm{J}$ et al. Reversible prevention of platelet activation by $(E, Z)-4,5,9$-trithiadodeca-1,6,11-triene 9-oxide (ajoene) in dogs under extracorporeal circulation. Arzneimittelforschung 1988; 38: 901-4.

256 Dirsch VM, Gerbes AL, Vollmar AM. Ajoene, a compound of garlic, induces apoptosis in human promyeloleukemic cells, accompanied by generation of reactive oxygen species and activation of nuclear factor kappaB. Mol Pharmacol 1998; 53: 402-7. 



\author{
Chapter 2: \\ A hairy issue
}

\title{
Human follicular stem cells: \\ Their presence in plucked hair and follicular cell culture
}

Coen G.Gho MD*.†, Jacqueline E.F.Braun PhD*. ${ }^{*}$, Claudia M.L.J. Tilli ${ }^{\dagger}$, Frans C.S. Ramaekers $\mathrm{PhD}^{\ddagger}$, H.A. Martino Neumann MD, $\mathrm{PhD}^{\S}$

Research Institute Growth \& Development (GROW)

$\dagger$ Department of Dermatology, University Hospital Maastricht and Medical Center Annadal, Maastricht, The Netherlands

‡ Department of Molecular Cell Biology, University of Maastricht, The Netherlands

$\S$ Department of Dermatology and Venereology, Erasmus University Rotterdam, The Netherlands

* These authors contributed equally to the studies presented in this manuscript

In press (British Journal of Dermatology) 


\section{Summary}

\section{Background / Objectives}

A considerable portion of the hair follicle remains attached to plucked hair and can be used for follicle cell culture. In this study we have phenotyped these cells in an attempt to identify the stem cell fraction. Reports in the literature have indicated that this cell population may be positive for cytokeratin (CK) 19. Since stem cells in general need to be protected from apoptosis, the presence of the apoptosis suppressing $\mathrm{Bcl}-2$ protein, together with the absence of the apoptosis promoting Bax and the CK profile may, be used as an indicator of the stem cell population in the hair follicle, and in cultures of hair follicle cells.

\section{Methods}

Hair follicles from skin biopsies and plucked hair were derived from the scalps of healthy volunteers. Follicular cells were cultured from the plucked hairs. These hair follicles, plucked hairs, and cultured cells were examined for their CK profiles, which are indicative of the type of cell (basal/stem cells), and for their status with respect to the proliferation marker $\mathrm{Ki}-67, \mathrm{Bax}$, and $\mathrm{Bcl}-2$.

\section{Results}

We found co-expression for CK19 and Bcl-2, but not Bax in two distinct areas, localized in the upper and lower third of the follicle from both skin biopsies and plucked hairs, while proliferation markers were negative in these areas. CK19 and $\mathrm{Bcl}-2$ were also co-expressed in combination in a fraction of the follicular cell culture. The skin basal cell marker CK14 could be found throughout the outer root sheath of the hair follicle from both skin biopsies and plucked hairs, as well as in the follicular cell culture.

\section{Conclusions}

Thus, CK19 / Bcl-2-positive and Bax-negative cells can be obtained from cells derived from plucked hair and are retained in cultures made from these cells. If this phenotype represents follicular stem cells, our finding endorses the assumption that stem cells are located in the bulge area of the hair follicle, as we did not find them in or near the dermal papilla. 


\section{Introduction}

Although a considerable portion of the hair follicle is attached to plucked hair, transplantation of a plucked hair does not result in normal hair growth ${ }^{1}$, in contrast to hair from micro-punch grafts ${ }^{2}$. This can be explained by the fact that the structures of the hair follicle that are retained in the skin after the hair is plucked, are necessary for normal hair growth. However, when outer root sheath (ORS) cells derived from plucked hairs are cultured, they can develop into a differentiated epidermis ${ }^{3}$, suitable for use in skin grafts ${ }^{4}$. We therefore speculated that the plucked hairs themselves might contain epidermal stem cells.

When plucked hair is dissected, the various transverse sections have been shown to exhibit different proliferative and differentiative characteristics ${ }^{5}$. It has been suggested that adult human follicular stem cells from terminal hairs are situated in the bulge area of the follicle. These cells have been suggested to exhibit various specific biochemical properties. For example they have epidermal growth factor (EGF) receptors, show alpha2beta1- and alfa3beta1integrin expression ${ }^{6}$, high levels of alpha6-integrins and low levels of the proliferation marker $10 \mathrm{G} 7^{7}$, and stain positively for platelet-derived growth factor (PDGF)-A/PDGF-B ligand chains. They do not contain nectadrin, or heat-stable antigen (CD24), a glycoprotein thought to be involved in cell-cell adhesion and signaling, which is also expressed in the outer epithelial sheath of human hair follicles and in glabrous epidermis ${ }^{8,9}$. However the CK apoptosis resistance profiles seem to have become key indicators of a stem cell phenotype.

During development into a terminal hair, the CK profile of the follicular keratinocyte changes. It has been proposed that CK19 is an indicator of the stem cell population ${ }^{10-13}$. CK19 is present in immature epithelial progenitor cells $^{14}$, but in the hair follicle it is specific for follicular stem cells ${ }^{10.11}$. In adult hair follicles, CK19 can be found in the outermost cells of the ORS at the isthmus and in some cells of the lower ORS ${ }^{10}$. It is proposed that the actual follicular stem cells are CK19-positive and lack connexin (Cx) 43, a specific differentiation marker for a gap junction protein.

A balance between cell proliferation, differentiation and apoptosis is essential for hair growth ${ }^{15,16}$, while stem cells must be protected against apoptosis. This protection is achieved by proteins such as $\mathrm{Bcl}-2$, while Bax, a conserved homologue that heterodimerizes with $\mathrm{Bcl}-2$ promotes cell death ${ }^{17}$. The characteristics of the CK profile, in particular the expression of CK19, but also CK5 and CK14 as basal cell markers ${ }^{11}$, together with the expression of $\mathrm{BCl}-2$ and absence of Bax expression, may therefore be used as indicators of the stem cells in the hair follicle.

The aim of this study was to localize the follicular stem cells in the hair follicle from skin biopsies and to characterize them on the basis of their CK phenotype, presence of $\mathrm{Bcl}-2$, and absence of Bax. Furthermore, we wished to determine whether these cells are present in plucked hair and preserved in cell cultures derived therefrom. 


\section{Materials and Methods}

\section{Skin biopsies}

Five healthy volunteers, three males and two females between the ages of 28 and 53 years (mean age 37 years) donated skin biopsies.

\section{Biopsies}

Four 3-mm punch biopsies were obtained from the occipital area of the scalp after local anaesthesia with lidocaine $2 \%$. The tissue samples were immediately frozen in liquid nitrogen and stored at $-80^{\circ} \mathrm{C}$ until use. Samples were then cut into $5-\mu \mathrm{m}$ thick sections in a vertical direction and carefully placed on Superfrost plus slides (Menzel-Glaser, Germany).

\section{Plucked hair}

Plucked hairs were obtained by removing the hairs with a depilation forceps from the occipital area of the scalp. Hair follicles in the anagen phase were selected under a dissection microscope, and embedded in Tissue Tek (Sakura Finetek Europe B.V., Zoeterwoude, The Netherlands), and directly cut into 5- $\mu \mathrm{m}$ sections as described above.

\section{Cell cultures}

Plucked hairs were placed in a Petridish with Defined Serum-Free Keratinocyte Growth Medium (dSFK; Life Technologies B.V. Breda, The Netherlands). The nonviable, keratinised part of the hair follicle was removed under a dissection microscope. The hair follicles were subsequently put in a sterile culture disk and incubated in dSFK containing $20 \mathrm{U} / \mathrm{ml}$ dispase (Sigma-Aldrich Chemie BV, Zwijndrecht, The Netherlands) for 30 minutes in a $\mathrm{CO}_{2}$ incubator at $37^{\circ} \mathrm{C}$. After this pre-incubation step, the hair follicles were transferred to a 24-well culture disk containing dSFK with $500 \mu \mathrm{g} / \mathrm{ml}$ penicillin (Life Technologies B.V. Breda, The Netherlands) and $0.25 \mu \mathrm{g} / \mathrm{ml}$ streptomycin (Life Technologies B.V. Breda, The Netherlands), and placed for 14 days at $31^{\circ} \mathrm{C}$ in a humidified atmosphere containing $5 \% \mathrm{CO}_{2}$. The culture medium was carefully removed every three days and replaced by fresh culture medium. The cells remained attached to the hair follicles during this culture period. After 14 days the culture medium was removed and replaced by a $0.5 \mathrm{mg} / \mathrm{ml}$ trypsin, $0.2 \mathrm{mg} / \mathrm{ml}$ EDTA (ethylene diaminetetraacetic acid) solution (Life Technologies B.V. Breda, The Netherlands), and incubated for 5 minutes at $37^{\circ} \mathrm{C}$ in this medium. After this incubation period clusters of cells were released from the hair follicles. These were harvested by centrifugation at $300 \mathrm{~g}$ at $4^{\circ} \mathrm{C}$ for 5 minutes in an Eppendorf 5804R Centrifuge (VWR International, The Netherlands). Subsequently the trypsin/EDTA medium was removed and replaced by culture medium. Cytospins were made from these cells in the Cytospin 3 (SHANDON, Zeist, The Netherlands) by centrifugation at $600 \mathrm{rpm}$ for 5 minutes. 
Table 1: Antibodies and their dilutions used in this study

\begin{tabular}{|c|c|c|c|c|}
\hline Antibody & Isotype & Antigen & Dilution & Source \\
\hline \multicolumn{5}{|c|}{ Basal cell markers } \\
\hline LL002 & mouse $\lg _{3}$ & CK 14 & UD & Purkis et al. ${ }^{39}$ \\
\hline RCK107 & mouse lg $\mathrm{G}_{1}$ & CK 14 & UD & Wetzels et al. ${ }^{40}$ \\
\hline RCK108 & mouse lgG 1 & CK 19 & $1: 5$ & Kwaspen et al. ${ }^{41}$ \\
\hline LP2K & mouse $\lg G_{2 b}$ & CK19 & UD & Stasiak et al. ${ }^{42}$ \\
\hline \multicolumn{5}{|c|}{ Proliferation markers } \\
\hline LL025 & mouse $\lg G_{1}$ & CK 16 & $1: 10$ & Wetzels et al. ${ }^{40}$ \\
\hline MIB-1 & mouse $\lg G_{1}$ & Ki-67 & $1: 25$ & $\begin{array}{l}\text { Immuno Technology, } \\
\text { Marseille, France }\end{array}$ \\
\hline $\mathrm{A} 0047$ & rabbit lgG & Ki-67 & $1: 100$ & $\begin{array}{l}\text { DAKOA/S,Glostrup, } \\
\text { Denmark }\end{array}$ \\
\hline \multicolumn{5}{|c|}{ Apoptosis markers } \\
\hline $\mathrm{N}-19$ & rabbit lgG & $\mathrm{Bcl}-2$ & $1: 200$ & $\begin{array}{l}\text { Santa Cruz } \\
\text { Biotechnology Inc., } \\
\text { Santa Cruz, CA, USA }\end{array}$ \\
\hline 124 & mouse $\lg \mathrm{G}_{1}$ & Bcl-2 & $1: 80$ & $\begin{array}{l}\text { DAKO A/S, Glostrup, } \\
\text { Denmark }\end{array}$ \\
\hline PC66 & rabbit lgG & Bax & $1: 750$ & $\begin{array}{l}\text { Oncogene Research } \\
\text { Products, Cambridge, } \\
\text { MA, USA }\end{array}$ \\
\hline
\end{tabular}

\section{Immunocytochemistry and antibodies}

The sections and cytospins were dried at room temperature for at least $1 \mathrm{~h}$, fixed in acetone (at $-20^{\circ} \mathrm{C}$ ) and processed for immunohistochemical staining. For the single immunostaining procedure, the slides were incubated overnight at $4^{\circ} \mathrm{C}$ with the primary antibodies. All incubations were carried out in phosphate-buffered saline (PBS) pH 7.4 at the appropriate dilution (table 1). The following day the slides were washed with PBS and incubated at room temperature for $30 \mathrm{~min}$ with the appropriate immunofluorescent-labeled secondary antibody (table 1). After extensive washing, the slides were mounted with a 4,6- diamidino-2-phenylindole (DAPI)-containing mounting agent (Vector Laboratories Inc., Burlingame, CA, USA) and stored at $-20^{\circ} \mathrm{C}$.

For double-immunostaining, the primary antibodies were selected on the basis of their isotypes, or a combination of monoclonal (mouse source) and polyclonal (rabbit source) antibody was applied as described in table 1. The first primary antibody was incubated overnight at $4^{\circ} \mathrm{C}$ and the next day, after washing, the second primary antibody was incubated at room temperature for $2 \mathrm{~h}$. After extensive washing in PBS, a mix of the appropriate secondary antibodies was applied and incubated for $30 \mathrm{~min}$ at room temperature. Subsequently the slides were washed in PBS, mounted as described above, and stored at $-20^{\circ} \mathrm{C}$.

Amplification of signal was achieved by incubation with biotinylated goat-antirabbit (BIO-GAR) or biotinylated goat-anti-mouse (BIO-GAM) and Avidin-Biotin complex (Vectastain ABC kit, Vector Laboratories Inc., Burlingame, CA, USA) after incubation with the primary antibody. Detection of peroxidase activity and 
simultaneous signal amplification was achieved by incubation with tetramethylrhodamine isothiocyanate (TRITC)-labeled tyramide or fluorescein isothiocyanate (FITC)-labeled tyramide ${ }^{18}$.

\section{Results}

HE staining of skin biopsies and plucked hair Comparison of the hair follicles derived from skin biopsies and from plucked hairs using light microscopy revealed that most of the epithelial structures from the hair follicle remain attached to the plucked hair (Fig.1).

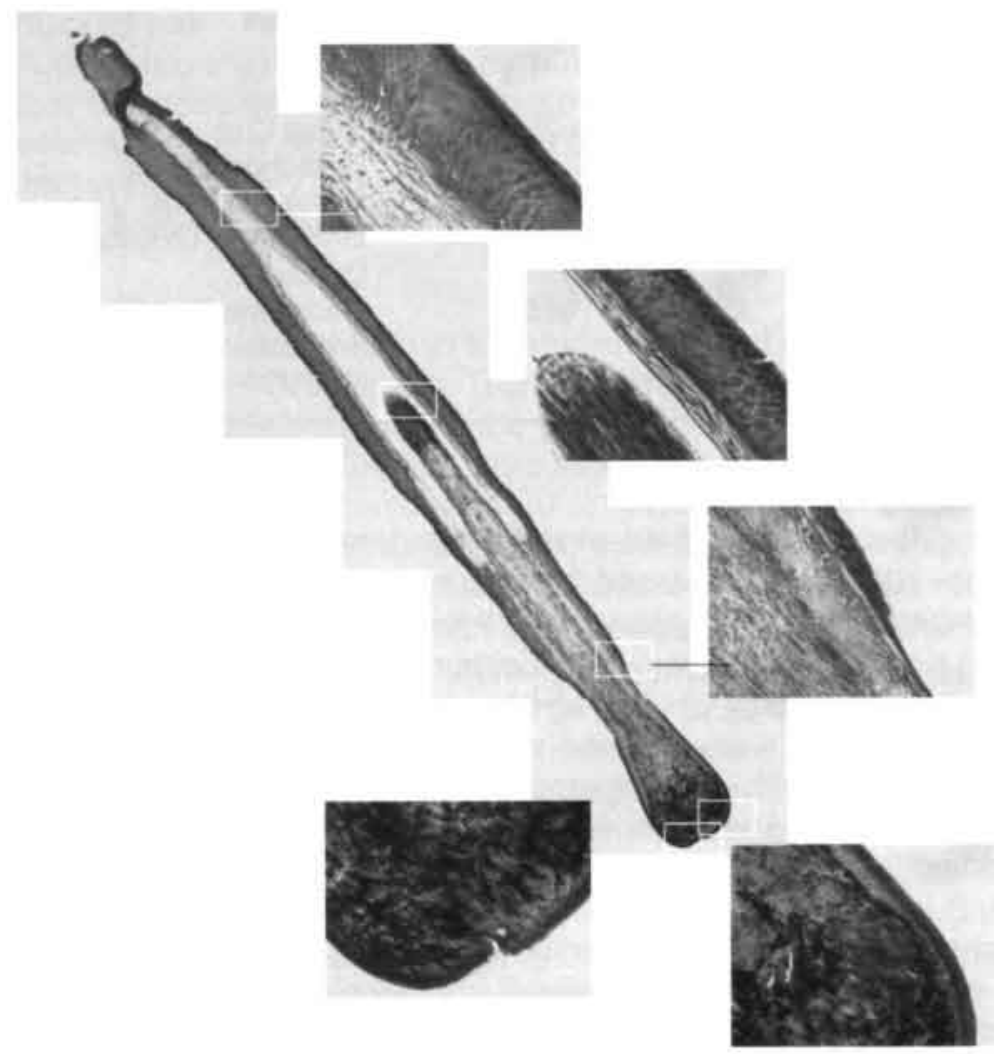

Figure 1: H\&E staining of plucked hair. Most epithelial structures from the follicle remain attached to the plucked hair. Adjacent to the longitudinal section of the plucked hair (x10) the respective areas are shown at a higher magnification (x40).

\section{Basal cell makers: CK14 and CK19}

Cells positive for the basal cell markers CK14 (RCK107, LL002) were found in the basal cells throughout the whole length of the ORS of the hair follicle and in the basal cell layer of stratified epithelium of the epidermis, both in the skin biopsy samples and in the plucked hairs. 

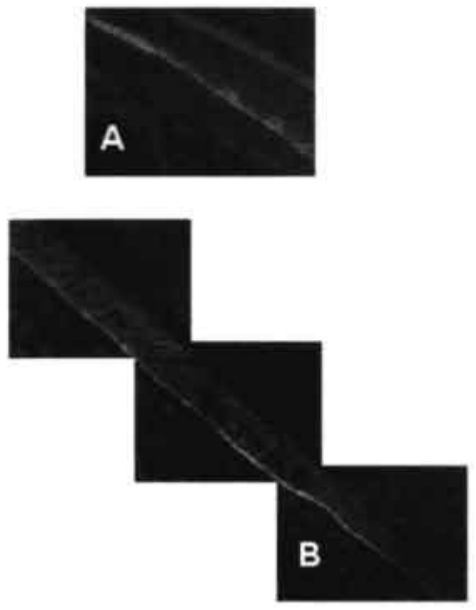

Figure 2: A) Details ( $\times 40)$ from a longitudinally sectioned hair follicle from skin biopsies double stained for CK19 in red and $\mathrm{Bcl}-2$ in green. Two areas were found to be positive for both markers; i.e. the upper third (A) and lower third (B) of the hair follicle.

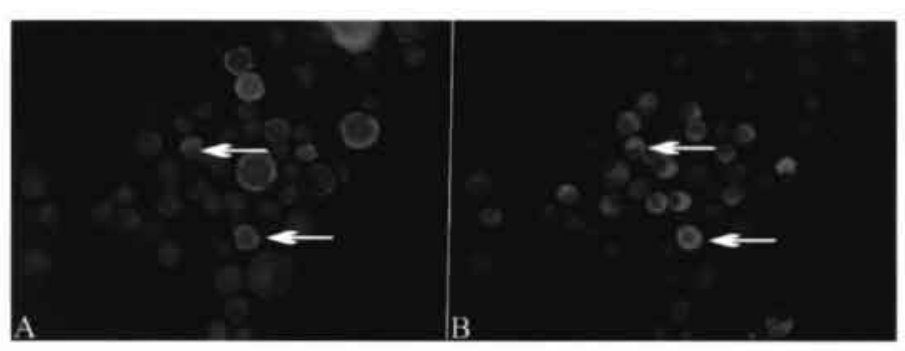

Figure 3: A) $\mathrm{Bcl}-2$ and B) CK19 staining of cells, derived from plucked hair and cultured for 14 days. Next to cells that are positive for both markers (arrows), some cells are only Bcl-2 or CK19 positive.

Figure 4: Details $(x 40)$ from a longitudinally sectioned dermal papilla (A) and hair follicle (B) from skin biopsies double stained for Bax in red and $\mathrm{Bcl}-2$ in green.
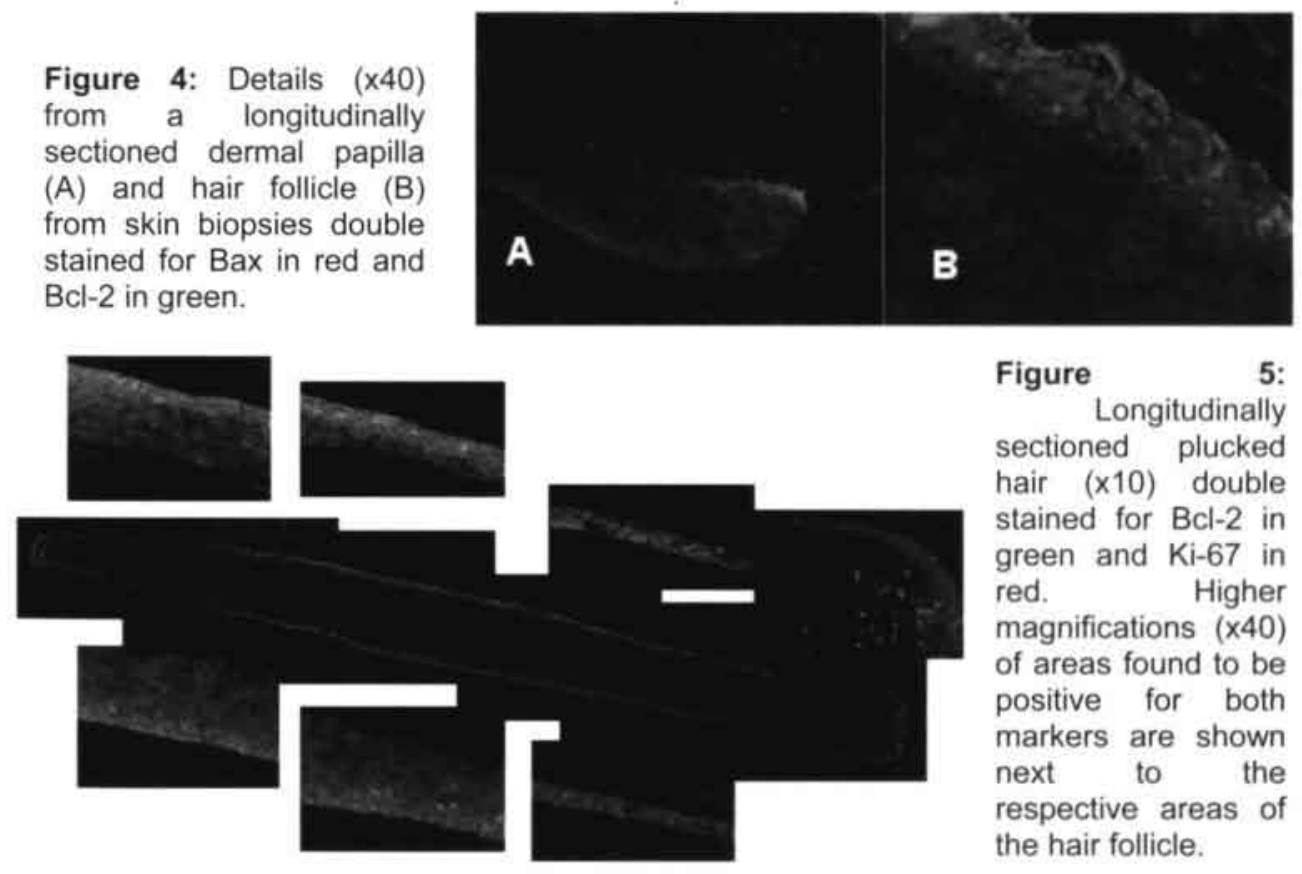

Figure

5: Longitudinally sectioned plucked hair (x10) double stained for $\mathrm{Bcl}-2$ in green and $\mathrm{Ki}-67$ in red. Higher magnifications ( $\times 40)$ of areas found to be positive for both markers are shown next to the respective areas of the hair follicle. 
In the hair follicles from the skin biopsy, the basal keratinocyte cell marker CK19 (RCK108, LP2K) was found in the most peripheral cell layer in two distinct areas in the upper (Fig 2A) and lower third (Fig 2B) of the ORS, but not in the epidermis. In the plucked hair, the same regions were found to be positive for CK19 (Results not shown). In follicular cell cultures approximately one fifth of the cells were CK19 positive. These CK19-positive cells were mostly found as cell clusters, as shown in Fig. 3B.

A complete overlap of CK19 (RCK108) and CK14 (LL002) was found in the biopsy samples and in plucked hair, and in approximately $40 \%$ of the cultured cells (not shown).

\section{(Anti-) Apoptosis markers: $\mathrm{Bcl}-2$ and Bax}

Bcl-2 (N-19) positive cells were found in the outermost cell layer throughout the whole length of the ORS of the hair follicle from skin biopsies, as well as in the basal layer of the epidermis. We also found $\mathrm{Bcl}-2$ positive cells in the most peripheral cell layer of the whole length of the ORS of the plucked hairs. Bcl-2 positive cells were not found in the dermal papilla. Double staining for CK19 (LP2K) and Bcl-2 ( $\mathrm{N}-19)$ revealed that CK19-positive cells were also positive for Bcl-2. However, not all Bcl-2-positive cells were positive for CK19 (Fig. 2A, B).

In the follicular cell cultures subjected to double-staining techniques, some cells stained positive for both $\mathrm{Bcl}-2$ and $\mathrm{CK} 19$, while others were positive for either Bcl-2 or CK19 (Fig.3A,B). Figure 3B shows a typical cluster of CK19 positive cells, found in the cytospins of the cell cultures.

Bax (PC66)-positive cells were present in the internal part of the ORS both in the hair follicles from skin biopsies and in the plucked hair. Bax-positive cells were found in the dermal papilla in the hair follicles from skin biopsies (Fig. 4A) and in the most proximal part of the plucked hair (Fig. 4B). Almost no overlap $(<5 \%)$ between Bcl-2 (124) and Bax (PC66)-positive cells was found in either sample. However, in follicular cell culture there was more overlap $(30-40 \%)$ between $\mathrm{Bcl}-2$ - and Bax-positive cells (results not shown).

\section{(Hyper-) Proliferation markers CK16 and Ki-67}

CK16 (LL025)-positive cells were found in the distal internal part of the ORS of the hair follicles, both from skin biopsies and plucked hairs. No CK16 staining was observed in the most proximal part of the hair follicles, either from skin biopsies or plucked hairs. CK16-positive cells were found in the internal part of the ORS, in contrast to CK19-positive cells whose position was more peripheral. There was no overlap between CK16 and CK19 staining in the hair follicles from skin biopsies, plucked hairs or follicular cell culture. There was an overlap in the immunostaining patterns of CK14 (LL002) and CK16 (LL025) in the ORS of the hair follicles from skin biopsies and in the plucked hair, where CK16-positive cells were located. In follicular cell culture there was virtually a total overlap between CK14- and CK16-positive cells (not shown).

Ki-67-positive cells were sporadically found (Fig 5). Their location tends to be more toward the internal part of the ORS, although some were found near the external part of the ORS near the CK19-positive cells. Ki-67-positive cells were also found in the dermal papilla. Less than $1 \%$ of Ki-67-positive cells were found in follicular cell culture. 


\section{Discussion}

Although plucked hair seems to contain all of the epithelial structures that are present in the hair follicle derived from skin biopsies, the transplantation of plucked hair does not result in normal hair growth, in contrast to hair-containing punch grafts ${ }^{1}$. The fact that the structures of the hair follicle remaining in the skin can produce a normal hair, suggests that follicular stem cells are retained in the skin. However, when hair follicle preparations derived from skin biopsies are compared with preparations from plucked hair under a light microscope, it can be seen that the majority of the epithelial structures from the hair follicle remains attached to the plucked hair. The question thus arises whether or not follicular stem cells are extracted with the plucked hair, and whether the stromal tissue surrounding these epithelial structures is necessary for induction of hair growth. This follicular connective tissue has specific biochemical characteristics, such as the presence of PDGF-alpha and PDGF-beta receptors and versican ${ }^{19,20}$, that seem to play a role in (embryonic) hair follicle development and cycling.

We based our search for the follicular stem cell population in plucked hair and cultures thereof on stem cell characteristics proposed in the recent literature ${ }^{9}$, i.e. the expression of $\mathrm{CK} 19$ and $\mathrm{Bcl}-2$, in combination with the absence (or low levels) of Bax expression ${ }^{21}$, and an extremely low proliferation frequency ${ }^{22}$. In 1996, Michel et al. ${ }^{23}$ suggested that CK19-positive cells in hair follicles represent stem cells. Furthermore, stem cells in general express $\mathrm{Bcl}-2^{24.25}$. In normal skin, $\mathrm{Bcl}-2$ is only expressed by a limited population of cells in the basal compartment, which can be regarded as the stem cell compartment ${ }^{26}$.

An important finding in this study is that phenotypical characteristics of the hair follicle from skin biopsies are preserved in plucked hair, including the expression of $\mathrm{CK} 19^{10}$ and $\mathrm{Bcl}-2^{16}$ in cells from two areas of the upper and lower third of the follicle. Positivity for CK19 and Bcl-2 corresponds to infrequent cell division in these areas, as concluded from the absence of Ki-67 staining. The fact that these cells are positive for Bcl-2 and CK 19, but Ki-67 and Bax negative, is a strong indication that they represent stem cells in the hair follicle. Our results also indicate that transient amplifying cells in the epidermis, which are expected to be $\mathrm{Ki}-67$ positive, are largely $\mathrm{Bcl}-2$ negative. All the markers found in the hair follicle from skin biopsies were also preserved in the follicular cell culture derived from plucked hair, including $\mathrm{CK} 19$ and $\mathrm{Bcl}-2$, and the basal cell marker CK14. We therefore conclude that viable follicular stem cells can be obtained from plucked hairs. The low frequency of Ki-67 positive cells indicates that differentiation may have occurred in these cell cultures, which can also be concluded from the CK10 staining in a proportion of the cells (unpublished observation).

The observation that two distinct areas in the hair follicle from skin biopsies are positive for CK19 was also found by Commo et al. ${ }^{13}$. The fact that these areas are also $\mathrm{Bcl}-2$ positive, and Bax negative, is a strong indication for two stem-cell sites. The question therefore arises whether or not both areas are necessary for hair growth induction. In humans, Kim et al. ${ }^{27}$ found that the proximal part of the hair follicle cannot regenerate into a differentiated hair follicle, but the distal part of the follicle can, eventually resulting in a fully developed hair follicle ${ }^{28}$. 
Reynolds et al. ${ }^{29}$ found that, although the dermal papillae of humans cannot induce new hair growth, the sheath of the lower part of the hair follicle can. These apparently contradictory results indicate that both proximal and distal areas of the hair follicle can induce hair growth, which agrees with our finding of two stem cell locations.

In addition to these two areas, the dermal papilla has also been ascribed a key role in hair growth. In rats, cultured dermal papilla cells from whisker hairs can generate a fully differentiated hair follicle ${ }^{30}$, suggesting that follicular stem cells are located in or near the dermal papilla. The cells in this region that are held responsible for hair growth are the germ cells. Recently a hypothesis of hair cycling was proposed that involves participation of these germ cells next to the bulge region stem cells ${ }^{31}$. In our study, the dermal papilla in the hair follicle of the skin biopsy did not contain Bcl-2. In contrast other studies have found $\mathrm{Bcl}-2$ positivity in the dermal papilla ${ }^{16,32}$, but the tissues used in these studies were either embryonic or derived from non-melanoma skin cancers. The apparent discrepancy in findings could be due to the fact that, although $\mathrm{Bcl}-2$ is normally found in the basal compartment of normal skin, there is an expansion of this Bcl-2 positive cell population under pathological circumstances such as basal cell carcinoma $(\mathrm{BCC})^{26,33}$.

In our study we found that the dermal papilla is positive for Ki-67 and Bax. This immunophenotype, in combination with the $\mathrm{Bcl}-2$ negativity, is not in agreement with the characteristic definition of a follicular stem cell population, but rather supports the findings of others that follicular stem cells are not present in the dermal papilla ${ }^{15,34}$. However, taken all these findings together suggests that hair growth involves the co-operation of various stem cell regions.

The inability to successfully transplant plucked hairs containing the two stem cell regions may be due to the lack of appropriate conditions in the stromal tissue of the recipient areas. A similar lack of growth has been observed in case of transplanted epithelial structures derived from BCC which could not be induced to proliferate without the transplantation of additional stromal cells ${ }^{35}$. This comparison is justifiable since BCC are most likely derived from follicular germinative cells ${ }^{36,37}$. Another indication of the importance of stromal cells for the growth of keratinocytes is the observation that keratinocyte cultures may require a fibroblast feeder layer ${ }^{3}$.

Unsuccessful regeneration after implantation of plucked hairs may also be caused by the inflammatory response of the receptor area to the plucked hairs, which may result in the destruction of the follicular stem cells. The connective tissue surrounding these epithelial structures in micro-punch grafts may be crucial for protection against inflammation, and thus a successful transplantation. Therefore, the importance of the connective tissue of the hair follicle cannot be ignored ${ }^{1,38}$. Follow-up studies will focus on the role of components of the connective tissue and the extracellular matrix surrounding the epithelial portion of the hair follicle. 


\section{References}

1. Gho C G, Neumann H A. Hair transplantation of plucked hair biopsies. Dermatol Surg 2001;27(10):913.

2. Unger W, Nordstrom R. Hair Transplantation. 3rd ed; 1995.

3. Lenoir M C, Bernard B A, Pautrat G, et al. Outer root sheath cells of human hair follicle are able to regenerate a fully differentiated epidermis in vitro. Dev Biol 1988;130(2):610-20.

4. Kurata S, Itami S, Terashi H, et al. Successful transplantation of cultured human outer root sheath cells as epithelium. Ann Plast Surg 1994;33(3):290-4.

5. Moll I. Proliferative potential of different keratinocytes of plucked human hair follicles. J Invest Dermatol 1995;105(1):14-21.

6. Jones $P$ H. Harper $S$, Watt $F$ M. Stem cell patterning and fate in human epidermis. Cell 1995;80(1):83-93.

7. Li Y, Pirro A, Amling M, et al. Targeted ablation of the vitamin D receptor: an animal model of vitamin D-dependent rickets type II with alopecia. Proc Natl Acad Sci U S A 1997;94(18):9831-5.

8. Magnaldo T, Barrandon Y. CD24 (heat stable antigen, nectadrin), a novel keratinocyte differentiation marker, is preferentially expressed in areas of the hair follicle containing the colony-forming cells. J Cell Sci 1996:109(Pt 13)():3035-45.

9. Stenn K, Paus R. Controls of hair follicle cycling. Physiol Rev 2001;81(1):449494.

10. Asada M, Kurokawa I, Nishijima S, et al. [An immunohistochemical study on cell differentiation in the outer root sheath of the normal human anagen hair follicles with antikeratin monoclonal antibodies]. Nippon Hifuka Gakkai Zasshi 1990;100(14):1423-30.

11. Schirren C G, Burgdorf W H, Sander C A, et al. Fetal and adult hair follicle. An immunohistochemical study of anticytokeratin antibodies in formalin-fixed and paraffin- embedded tissue. Am J Dermatopathol 1997;19(4):335-40.

12. Lane E, Wilson C. Hughes B, et al. Stem cells in hair follicles. Cytoskeletal studies. Ann N Y Acad Sci 1991;642:197-213.

13. Commo S, Gaillard O, Bernard B A. The human hair follicle contains two distinct K19 positive compartments in the outer root sheath: a unifying hypothesis for stem cell reservoir? Differentiation 2000;66(4-5):157-64.

14. Haruna $\mathrm{Y}$, Saito $\mathrm{K}$, Spaulding $\mathrm{S}$, et al. Identification of bipotential progenitor cells in human liver development. Hepatology 1996;23(3):476-81.

15. Paus R, Czarnetzki B M. The "bulge-activation hypothesis" does not explain hair follicle cycling but may still be valid [letter]. Am J Dermatopathol 1994;16(1):112-4.

16. Polakowska R R, Piacentini M, Bartlett R, et al. Apoptosis in human skin development: morphogenesis, periderm, and stem cells. Dev Dyn 1994;199(3):176-88.

17. Korsmeyer S J, Yin X M, Oltvai Z N, et al. Reactive oxygen species and the regulation of cell death by the $\mathrm{Bcl}-2$ gene family. Biochim Biophys Acta 1995;1271(1):63-6.

18. Hopman A H, Ramaekers F C, Speel E J. Rapid synthesis of biotin-, digoxigenin-, trinitrophenyl-, and fluorochrome-labeled tyramides and their application for In situ hybridization using CARD amplification. J Histochem Cytochem 1998;46(6):771-7.

19. Akiyama M, Smith L, Holbrook K. Growth factor and growth factor receptor localization in the hair follicle bulge and associated tissue in human fetus. $\mathrm{J}$ Invest Dermatol 1996;106(3):391-6. 
20. du Cros D L, LeBaron R G, Couchman J R. Association of versican with dermal matrices and its potential role in hair follicle development and cycling. J Invest Dermatol 1995;105(3):426-31.

21. Lindner G, Botchkarev V A, Botchkareva N V, et al. Analysis of apoptosis during hair follicle regression ( catagen) [see comments]. Am J Pathol 1997:151(6):1601-17.

22. Lavker R M, Sun T T. Hair follicle stem cells: present concepts. Journal of Investigative Dermatology 1995;104(5 Suppl)(May):38S-39S.

23. Michel M, N T ö, Godbout M J, et al. Keratin 19 as a biochemical marker of skin stem cells in vivo and in vitro: keratin 19 expressing cells are differentially localized in function of anatomic sites, and their number varies with donor age and culture stage. J Cell Sci 1996;109(Pt 5)():1017-28.

24. Harmsel ter B, Smedts F, Kuijpers J, et al. BCL-2 immunoreactivity increases with severity of $\mathrm{CIN}$ : a study of normal cervical epithelia, CIN, and cervical carcinoma. J Pathol 1996;179(1):26-30.

25. Crum C P. Contemporary theories of cervical carcinogenesis: the virus, the host, and the stem cell. Mod Pathol 2000;13(3):243-51.

26. Tilli C M, Stavast-Kooy A J, Ramaekers F C, et al. Bax expression and growth behavior of basal cell carcinomas. J Cutan Pathol 2002;29(2):79-87.

27. Kim J C, Choi Y C. Regrowth of grafted human scalp hair after removal of the bulb. Dermatol Surg 1995;21(4):312-3.

28. Kim J C, Kim M K, Choi Y C. Regeneration of the human scalp hair follicle after horizontal sectioning: implications for pluripotent stem cells and melanocyte resevoir. In: Van Neste DJJ, Randall VA, editors. Hair restoration for the next millenium: Elsevier Science B.V.; 1996. p. 135-139.

29. Reynolds A J, Lawrence C, Cserhalmi Friedman P B, et al. Trans-gender induction of hair follicles. Nature 1999;402(6757):33-4.

30. Jahoda C A, Horne K A, Oliver R F. Induction of hair growth by implantation of cultured dermal papilla cells. Nature 1984;Oct 11-17(311(5986)):560-2.

31. Panteleyev A A, Jahoda C A, Christiano A M. Hair follicle predetermination. J Cell Sci 2001;114(Pt 19):3419-31.

32. Rodriguez Villanueva J, Colome M I, Brisbay S, et al. The expression and localization of bcl-2 protein in normal skin and in non-melanoma skin cancers. Pathol Res Pract 1995:191(5):391-8.

33. Verhaegh M, Sanders C, Arends J, et al. Expression of the apoptosissuppressing protein $\mathrm{Bcl}-2$ in non-melanoma skin cancer. $\mathrm{Br} J$ Dermatol 1995;132(5):740-4.

34. Matsuzaki T, Inamatsu M, Yoshizato $K$. The upper dermal sheath has a potential to regenerate the hair in the rat follicular epidermis. Differentiation 1996;60(5):287-97.

35. Eichmann F, Schnyder U W. Das Basaliom. Berlin Heidelberg New York: Springer-Verlag; 1981.

36. Ackerman A. Histologic diagnosis of inflammatory skin diseases. Second edition ed: Williams \& Wilkins; 1997.

37. Stamp G W. Pignatelli M. Distribution of beta 1, alpha 1, alpha 2 and alpha 3 integrin chains in basal cell carcinomas. J Pathol 1991;163(4):307-13.

38. Jahoda C A, Reynolds A J. Dermal-epidermal interactions-follicle-derived cell populations in the study of hair-growth mechanisms. [Review]. J Invest Dermatol 1993:101(1 Suppl):33S-38S.

39. Purkis P E, Steel J B, Mackenzie I C, et al. Antibody markers of basal cells in complex epithelia. J Cell Sci 1990;97(Pt 1)():39-50.

40. Wetzels R H. Kuijpers H J, Lane E B, et al. Basal cell-specific and hyperproliferation-related keratins in human breast cancer. Am J Pathol $1991 ; 138(3): 751-63$. 
41. Kwaspen F H, Smedts F M, Broos A, et al. Reproducible and highly sensitive detection of the broad spectrum epithelial marker keratin 19 in routine cancer diagnosis. Histopathology 1997;31(6):503-16.

42. Stasiak P C, Purkis P E, Leigh I M, et al. Keratin 19: predicted amino acid sequence and broad tissue distribution suggest it evolved from keratinocyte keratins. J Invest Dermatol 1989;92(5):707-16. 



\section{Chapter 3:}

Bcl-2 Family

\section{1: Bax expression and growth behavior of basal cell carcinomas}

Claudia M.L.J.Tilli, ${ }^{1,2}$, Angela J.W.Stavast-Kooy ${ }^{1}$, Frans C.S.Ramaekers ${ }^{2}$, H.A. Martino Neumann ${ }^{1}$

Research Institute Growth \& Development (GROW), University Maastricht, The Netherlands

1) Dept. of Dermatology, University Hospital Maastricht, Maastricht, The Netherlands

2) Dept. of Molecular Cell Biology \& Genetics, University of Maastricht, Maastricht, The Netherlands

Published in Journal of Cutaneous Pathology (2002): 29: pp 79-87 


\section{Abstract}

\section{Background}

To understand the typical growth behavior of basal cell carcinoma (BCC) we searched for the correlation between proliferation and apoptosis and progression of BCC.

\section{Methods}

Expression of $\mathrm{Bcl}-2, \mathrm{Bax}$, and $\mathrm{Ki}-67$ was immunohistochemically investigated in both normal skin and BCC cells, as well as in the epidermis overlying BCC.

\section{Results}

The results showed that in normal epidermis, $\mathrm{Bcl}-2$ was homogeneously expressed in the basal cell compartment, whereas $\mathrm{Ki}-67$ expression was largely restricted to the parabasal layer, the layer just above the basal cell layer, and exhibited a more scattered staining pattern. Bax was occasionally expressed in the basal layer and widely in the suprabasal compartment. Strikingly, the apparently normal epidermis overlying $\mathrm{BCC}$ showed an increased $\mathrm{Bcl}-2$ staining. In BCC, cells stained homogeneously for $\mathrm{Bcl}-2$, whereas $\mathrm{Bax}$ and $\mathrm{Ki}-$ 67 showed scattered staining patterns. Simultaneous expression was seen for $\mathrm{Bcl}-2$ and $\mathrm{Bax}$ in $80 \pm 7 \%$ of the tumor cells, and co-expression of $\mathrm{Bcl}-2$ and $\mathrm{Ki}-$ 67 in $20 \pm 7 \%$ of the tumor cells. The cells expressing Bcl-2 and $\mathrm{Ki}-67$, but lacking expression of Bax, the progressive fraction, comprised on average $7 \pm 3 \%$ of the tumor cell population.

\section{Conclusion}

These results suggest that this small progressive fraction of tumor cells, in combination with the relatively high percentage of cells still prone to apoptosis, can explain the indolent growth behavior of BCC.

Keywords: basal cell carcinoma, proliferation, apoptosis, Bax, Bcl-2, Ki-67 


\section{Introduction}

Basal cell carcinoma (BCC), the most common malignancy in Caucasians, is a non-melanoma type of skin cancer arising predominantly in the face and neck. It is a typically slowly growing tumor with a great diversity in histopathological appearance . Although generally of indolent nature, occasionally the tumor can become very aggressive and destructive, a clinical behavior that is mainly related to the morpheaform, metatypical or micronodular phenotype ${ }^{1}$.

In general, growth of a tumor is based on a derailment of cell proliferation ${ }^{2}$. However, it has been shown in previous studies that the duration of a cell cycle in BCC resembles that of keratinocytes of the generative compartment of normal epidermis, approximately 217 hours $^{3}$. This is in contrast with the clinical observation that BCC is an extremely slowly growing tumor, which may take months or even years to double in size ${ }^{4}$. It has therefore been suggested that only a small percentage of all tumor cells is actively proliferating and it was found that these cells are mainly located at the periphery of the tumor nests ${ }^{5,6}$. In addition, an increase of the apoptotic potential of BCC cells may be another explanation for this phenomenon.

Apoptosis is partly regulated by the balance between the expression of antiapoptotic protein $\mathrm{Bcl}-2$ and the pro-apoptotic protein $\mathrm{Bax}(\mathrm{Bcl}-2$ associated $\mathrm{x}$ protein). The Bcl-2 gene was first discovered in B-cell-lymphomas showing a $t(14: 18)$ translocation ${ }^{7}$. The resulting fusion gene yielded an over-expression of the $\mathrm{Bcl}-2$ protein ${ }^{8}$. This translocation is frequently found in various cancers and it was shown by Reed et al that the Bcl-2 protein could suppress apoptosis induced by various stimuli. Bax was discovered in an immunoprecipitation assay when it co-precipitated with Bcl-2. Although it exhibits a high degree of homology with $\mathrm{Bcl}-2$, this protein showed pro-apoptotic activity ${ }^{10}$. Overexpression of Bax results in homodimerization and suppression of the functionality of Bcl-2, followed by the induction of apoptosis. Over-expression of $\mathrm{Bcl}-2$, however, results in cell survival. It can thus be concluded that the relative expression levels of these two proteins in part determine the fate of a cell ${ }^{10}$. Since most tumor cells in $\mathrm{BCC}$ show expression of $\mathrm{BCl}-2^{1}$, the expression level of the Bax protein may determine whether a cell lives or dies.

The slow expansive growth of BCC must therefore be explained in the light of the delicate balance between cell generation (proliferation) and cell loss (apoptosis), which is responsible for the tissue homeostasis in multi-cellular organisms, and becomes disturbed in tumor development.

The aim of this study was to determine and quantify the cell population in BCC that is responsible for its expansion i.e. the tumor cells that are protected from undergoing apoptosis (Bcl-2 positive, Bax negative) and are actively proliferating (Ki-67 positive). It was found that this cell population comprises a minor fraction of the tumor cells and is smaller than the cell fraction that can potentially undergo apoptosis. 


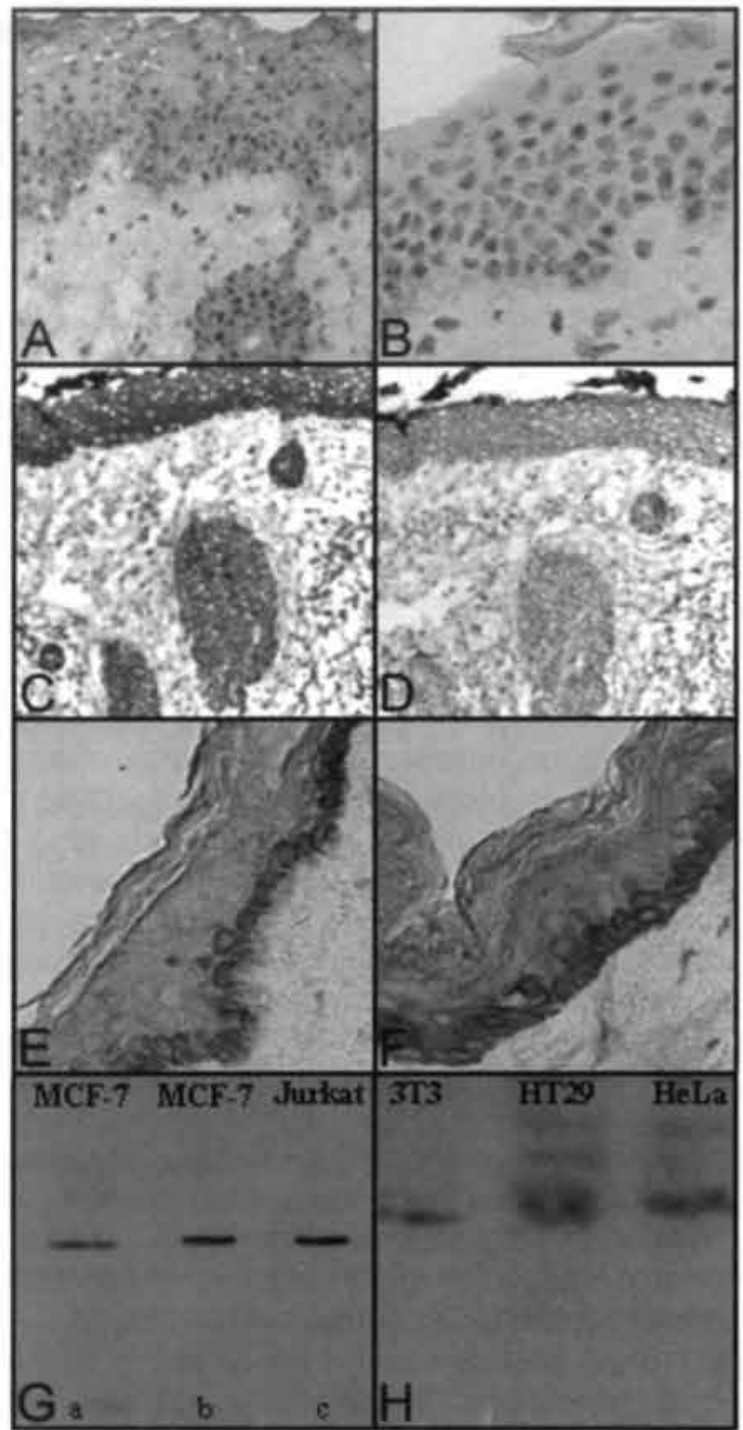

Figure 1: Specificity testing of the $\mathrm{Bax}$ and $\mathrm{Bcl}-2$ antibodies

A. Polyclonal Bax antibody (Ab1) in normal skin. Note sporadic expression in basal layer of the epidermis and more extensive expression in the suprabasal layers.

B. Polyclonal Bax antibody (Ab1) pre-incubated with blocking peptide: no staining present.

C. Polyclonal Bcl-2 antibody (N$19)$ in BCC: epidermis and tumor cells show expression of the $\mathrm{Bcl}$ 2 protein.

D. Polyclonal $\mathrm{Bcl}-2$ antibody ( $\mathrm{N}$ 19) pre-incubated with blocking peptide: no staining present.

E. Monoclonal $\mathrm{Bcl}-2$ antibody (Clone 100) in normal skin: basal layer positive, suprabasal layers negative.

F. Polyclonal $\mathrm{Bcl}-2$ antibody $(\mathrm{N}$ 19) in normal skin: comparable result as observed for the monoclonal antibody.

G. Immunoblotting results with the monoclonal (Clone 124, lane a) and polyclonal antibody ( $\mathrm{N}$ 19, lanes $b$ and $c$ ) against $\mathrm{BCl}-2$ : a single band is detected with both antibodies at the expected molecular weight of $29 \mathrm{kDa}$ in the MCF-7 and Jurkat cell lines. $\mathrm{H}$. Immunoblot with the polyclonal Bax antibody (Ab-1): one single band was detected at the expected molecular weight of $21 \mathrm{kDa}$ in 3 T3, HT29 and HeLa cell lines.

The $40 \mathrm{x}$ objective was used for photography of images $1 \mathrm{~A}-\mathrm{F}$. 


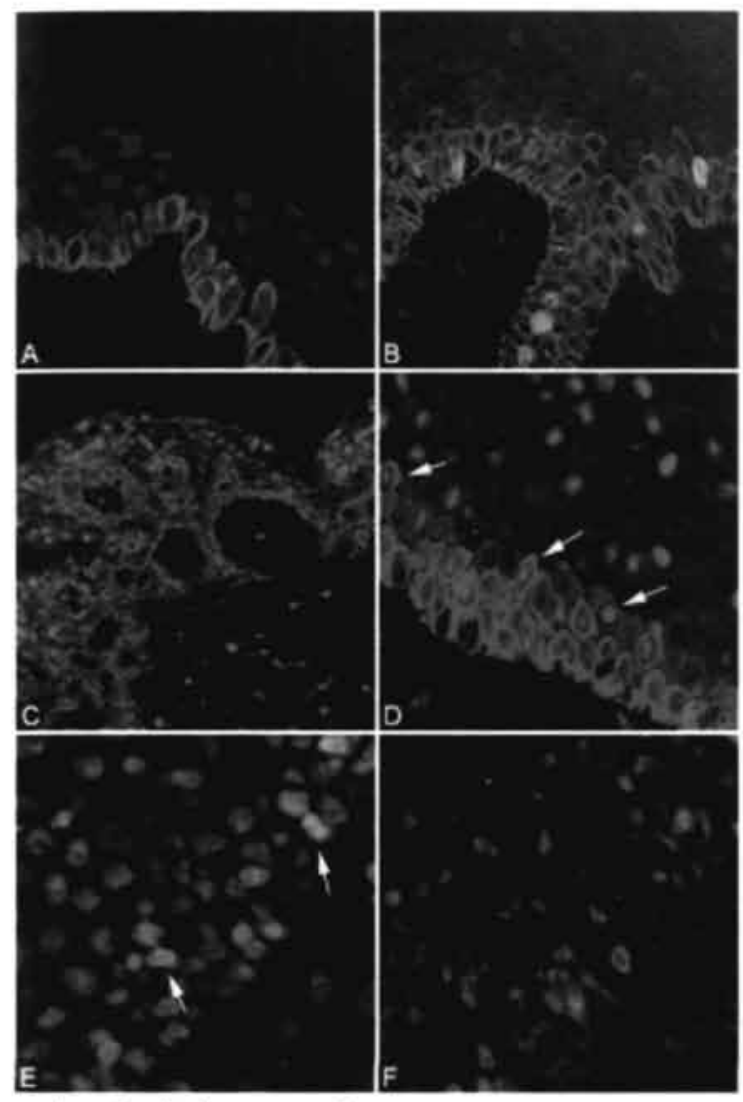

Figure 2: Proliferation- and apoptosis markers in the epidermis A. Bcl-2 (green) and $\mathrm{Ki}-67$ (red): $\mathrm{Bcl}-$ 2 was found to be present in the basal cell layer of the epidermis of normal skin, whereas $\mathrm{Ki}-67$ is mainly restricted to the parabasal layer.

B. Bcl-2 (green) and $\mathrm{Ki}-67$ (red) There are some clear differences in expression of $\mathrm{BCl}-2$ and $\mathrm{Ki}-67$ in the epidermis overlying BCC as compared to the expression patterns in normal epidermis. The expression is enhanced and simultaneous expression of the two markers occurs.

C. Bcl-2 (green) and Bax (red): Bax shows a low level of expression in the basal cell layer but is upregulated in the suprabasal layers of the epidermis. The expression patterns of Bcl-2 and Bax are mutually exclusive.

D. Bcl-2 (green) and Bax (red): A clear difference between the expression patterns of $\mathrm{Bcl}-2$ and $\mathrm{Bax}$ in epidermis overlying BCC and normal epidermis is that simultaneous expression of $\mathrm{Bcl}-2$ and Bax can occur in some parabasal cells (see arrows).

E. Bax (red) and $\mathrm{Ki}-67$ (green): The expression patterns of $\mathrm{Bax}$ and $\mathrm{Ki}$ 67 can show overlap in some

parabasal cells (see arrows).

F. Bax (red) and $\mathrm{Ki}-67$ (green): Increased number of cells showing $\mathrm{Ki}-67$ expression in the epidermis overlying a tumor as compared to normal epidermis.

The $40 x$ objective was used for photography of images $2 \mathrm{~A}-\mathrm{F}$.

\section{Figure 3: \\ Proliferation- and apoptosis \\ markers in the BCC:}

A. Bcl-2 (red) and $\mathrm{Ki}-67$ (green): BCC stains homogeneously positive for Bcl-2. while Ki-67 yields
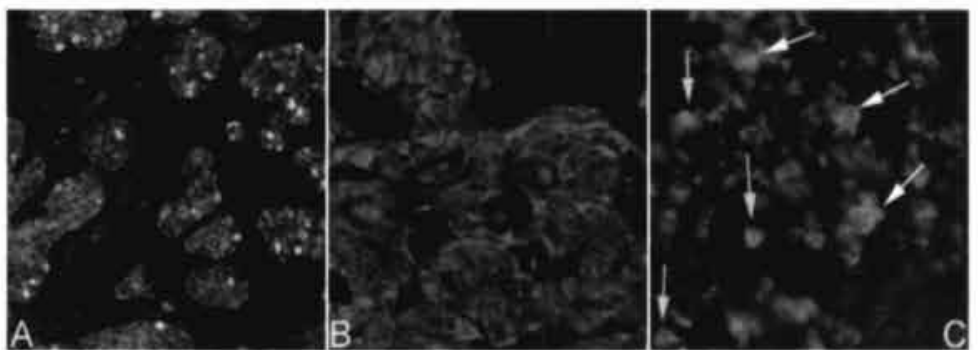

positive staining at the periphery of the nodules. Morpheic strands show a more scattered pattern of Ki-67 expression.

B. Bcl-2 (green) and Bax (red): BCC express Bcl-2 homogeneously, while Bax expression is found in $60-90 \%$ of the tumor cells.

C. Bax (red) and Ki-67 (green): Simultaneous expression occurs in tumor cells (white arrows), while also tumor cells are positive for $\mathrm{Ki}-67$ but negative for Bax (yellow arrows).

The $40 x$ objective was used for photography of images 3 A-C. 


\section{Materials and methods}

\section{Tissue material}

Normal skin was obtained from breast reduction surgery at the Department of Plastic Surgery of our hospital and was snap frozen in liquid nitrogen. Frozen sections $(5 \mu \mathrm{m})$ were cut and placed on slides coated with 3aminopropyltrietoxysilan (APTS) (Sigma-Aldrich Chemie BV, Zwijndrecht, The Netherlands).

Fresh frozen tumor material was obtained from 30 BCC patients treated by Mohs' micrographic surgery. The histological classification of the BCCs showed that twelve were nodular type, three were micronodular type, one was morpheaform type, two were nodular/morpheaform type, six were micronodular/morpheaform type, two were nodular/adenoid type and four were mixed type (Table 3 ). In all these cases the apparently normal overlying epidermis was also examined. Frozen sections $(5 \mu \mathrm{m})$ were cut and placed on APTS-coated slides.

\section{Methods}

\section{- Immunohistochemistry}

Specificity of the polyclonal antibodies was warranted by the fact that they are both affinity purified using the synthetic peptide used to immunize the rabbits. Furthermore, immunoblotting was performed for the monoclonal-and polyclonal antibody against $\mathrm{Bcl}-2$ and the polyclonal antibody against Bax as was described previously ${ }^{11}$, using the following cell lines: HeLa (human cervix adenocarcinoma), HT29 (human colorectal adenocarcinoma), 3T3 (mouse fibroblast), MCF-7 (human adenocarcinoma of the mammary gland), and Jurkat (human T cell leukemia) (ATCC in Manassas, VA, USA). In addition, the polyclonal antibodies against $\mathrm{Bax}$ and $\mathrm{Bcl}-2$ were pre-absorbed with the peptides used for immunization.

\section{- Immunoperoxidase staining}

Single antigen detection was performed using the immunoperoxidase staining method $^{12}$. Serial frozen sections were fixed in acetone and endogenous peroxidase activity was quenched by incubating the slides with $0.3 \%$ hydrogen peroxide in phosphate buffered saline (PBS). Nonspecific binding was blocked by incubation with normal goat serum. The slides were then incubated overnight at $4^{\circ} \mathrm{C}$ with the primary antibodies in optimal dilutions (Table 1).

The bound primary antibodies were linked with biotinylated secondary antibodies. The sections were then incubated with Avidin-Biotin complex horseradish peroxidase (Vector Laboratories Inc., Burlingame, CA, USA). Peroxidase activity was detected with the chromogen 3,3'-diaminobenzidine $(D A B)$ and the sections were counterstained with haematoxylin (Fluka A.G., Buchs, Germany).

\section{- Double-immunofluorescence staining}

Serial frozen sections were fixed in acetone and nonspecific binding was blocked by incubation with normal goat serum. The slides were then incubated 
with the primary antibodies, either subsequently or simultaneously, overnight at $4^{\circ} \mathrm{C}$. Table 2 shows the combinations of antibodies that were used.

For combinations A and B (Table 2) the overnight incubation was followed by incubation with peroxidase-conjugated goat-anti-mouse IgG (DAKO A/S, Glostrup, Denmark) and subsequently incubation with a mixture of Texas Redlabeled goat-anti-rabbit Ig (ITK Diagnostics, Uithoorn, The Netherlands) and fluorescein isothiocyanate (FITC)-labeled tyramide ${ }^{13}$ to detect peroxidase activity and simultaneous signal amplification.

For combinations C, D and E (Table 2), the slides were incubated with a mixture of FITC-labeled goat-anti-mouse Ig and Texas Red-labeled goat-anti-rabbit Ig.

For combination $\mathrm{F}$, overnight incubation with the polyclonal Bax antibody was followed by incubation with biotinylated goat-anti-rabbit and Avidin-Biotin complex (Vectastain ABC kit, Vector Laboratories Inc., Burlingame, CA, USA). Detection of peroxidase activity and simultaneous signal amplification was achieved by incubation with tetramethylrhodamine isothiocyanate (TRITC)labeled tyramide ${ }^{13}$. The slides were then incubated with the polyclonal $\mathrm{Bcl}-2$ antibody and subsequently with FITC-labeled goat-anti-rabbit Ig (ITK Diagnostics, Uithoorn, The Netherlands).

\section{Determination of percentages of positive cells}

The percentages of positive cells were estimated by counting 500 cells per tumor by two independent observers.

Table 1: Antibody characteristics and dilutions used in the single label immunoperoxidase staining procedure

\begin{tabular}{|c|c|c|}
\hline Antibody & Epitope & Manufacturer \\
\hline Clone 100 (monoclonal) & $\mathrm{Bcl}-2$ aa $44-52$ & $\begin{array}{l}\text { Santa Cruz Biotechnology Inc., } \\
\text { Santa Cruz, CA, USA }\end{array}$ \\
\hline Clone 124 (monoclonal) & Bcl-2 aa 41-54 & DAKO A/S, Glostrup, Denmark \\
\hline $\mathrm{N}-19$ (polyclonal) & Bcl-2 N-terminal & $\begin{array}{l}\text { Santa Cruz Biotechnology Inc., } \\
\text { Santa Cruz, CA. USA }\end{array}$ \\
\hline P-19 (polyclonal) & Bax N-terminal & $\begin{array}{l}\text { Santa Cruz Biotechnology Inc., } \\
\text { Santa Cruz, CA, USA }\end{array}$ \\
\hline Ab-1 (polyclonal) & Bax aa 150-165 & $\begin{array}{l}\text { Oncogene Research Products, } \\
\text { Cambridge, MA, USA }\end{array}$ \\
\hline MIB-1 (monoclonal) & $\mathrm{Ki}-67$ & Immunotech, Marseille, France \\
\hline A0047 (polyclonal) & $\mathrm{Ki}-67$ & DAKO A/S, Glostrup, Denmark \\
\hline
\end{tabular}

Abbreviation: $a \mathrm{a}=$ amino acids 
Table 2: Combinations of primary antibodies applied in the double-immunofluorescence assay

\begin{tabular}{ll}
\hline Combination & Antibodies and dilutions \\
\hline A & Clone $100(1: 10), \mathrm{N}-19(1: 200)$, simultaneous incubation \\
B & Clone $124(1: 50)$, A0047 $(1: 200)$, simultaneous incubation \\
C & N-19 $(1: 200)$, MIB-1 $(1: 25)$, simultaneous incubation \\
D & MIB-1 (1:25), P-19 $(1: 200)$, simultaneous incubation \\
E & Clone 124 (1:50), P-19 (1:200), simultaneous incubation \\
F & P-19 $(1: 1000), N-19(1: 200)$, subsequent incubation \\
\hline
\end{tabular}

\section{Results}

\section{Specificity testing of the immunoreagentia}

The specificity of the polyclonal- and monoclonal antibodies was warranted by several tests. Firstly, the polyclonal antibodies against Bax and Bcl-2 were preabsorbed with the peptides used for immunization, resulting in absence of staining when the corresponding peptide was used (Fig. 1A-D). Secondly, in normal epidermis, the monoclonal antibody against $\mathrm{Bcl}-2$ showed the same expression pattern of the protein as seen with the polyclonal antibody (Fig. 1E and $F$, respectively). In addition, the results of the immunoblotting showed the expected $29 \mathrm{kDa}$ band for both the monoclonal- and the polyclonal antibody against Bcl-2 (Fig. 1G). Furthermore, the expected $21 \mathrm{kDa}$ band for the polyclonal antibody against Bax was seen (Fig. $1 \mathrm{H})$.

\section{Proliferation- and apoptosis markers in the epidermis}

In normal skin, the expression of the $\mathrm{Bcl}-2$ protein was found to be restricted to the basal cell layer of the epidermis (Fig. 2A). This distribution pattern was seen with the monoclonal as well as the polyclonal antibodies. Ki-67 expression was found to be predominantly restricted to cells present in the parabasal layer, the layer just above the basal cell layer (Fig. 2A). These cells were either scattered throughout this layer, or clustered in certain areas. Again the polyclonal and monoclonal antibodies gave rise to the same results. In general, the staining patterns of $\mathrm{Ki}-67$ and $\mathrm{Bcl}-2$ were mutually exclusive, but occasionally some basal cells showed simultaneous expression. Bax was found to be expressed in the suprabasal layers of the epidermis, and in an occasional basal cell. The double immunofluorescence studies revealed also mutually exclusive expression of $\mathrm{Bcl}-2$ and $\mathrm{Bax}$ proteins in normal skin (Fig. 2C). Bax and $\mathrm{Ki}-67$ occasionally showed co-expression in the normal epidermis (Fig. 2E).

We noticed some striking differences in the epidermis overlying BCC as compared to the epidermis of normal skin. Epidermis overlying BCC showed increased numbers of cells positive for $\mathrm{Ki}-67$, with suprabasal layers of the epidermis also showing positive cells. With the monoclonal $\mathrm{Bcl}-2$ antibody a staining pattern similar to that in normal skin was seen, but when using the polyclonal Bcl-2 antibody also para- and suprabasal cells showed positive staining. As a result, cells with overlapping expression of $\mathrm{Bcl}-2$ and $\mathrm{Ki}-67$ were shown (Fig. 2B). Also Bax and $\mathrm{Bcl}-2$ could be detected simultaneously in the 
suprabasal layers of the epidermis overlying BCC (Fig. 2D). As in normal epidermis, the Bax and $\mathrm{Ki}-67$ staining patterns in the epidermis overlying $\mathrm{BCC}$ occasionally showed co-expression (Fig. 2F).

\section{Proliferation- and apoptosis markers in BCC (Table 3)}

$\mathrm{A}$ homogeneous staining pattern was found for $\mathrm{BCl}-2$ in $\mathrm{BCC}$ throughout the entire lesion, both for the polyclonal- and the monoclonal antibody. Expression of Ki-67 was shown in the tumor cells at the periphery of most of the nodules in the nodular type of $\mathrm{BCC}$, and in a somewhat more variable pattern in the morpheaform type of $\mathrm{BCC}$. The percentages of $\mathrm{Ki}-67$ expressing cells varied greatly amongst the various histological types and within an individual tumor (6$32 \%$ ) with an average of almost $20 \%$ (Table 3 ). Areas with a high number of cells expressing $\mathrm{Ki}-67$ occurred however adjacent to areas with a lower number of Ki-67 positive cells (Fig. 3A)

The expression of the Bax protein showed a scattered staining pattern which varied among the different types of $\mathrm{BCC}$ and within the individual tumors (Fig. $3 \mathrm{~B}$ ), but on average it was found in approximately $80 \%$ of the tumor cells. The percentages of cells showing simultaneous expression of Bax and $\mathrm{Ki}-67$ varied widely (4-25\%) between tumors (Table 3 and Fig. $3 \mathrm{C}$ ), and a correlation with the histopathological type could not be found. The proliferative (Ki-67 positive) fraction of the tumor consisted of cells either expressing or not expressing Bax. It is shown in Figure 4 that within the proliferative compartment of each individual tumor the percentage of Bax positive cells was higher than the percentage of Bax negative cells.

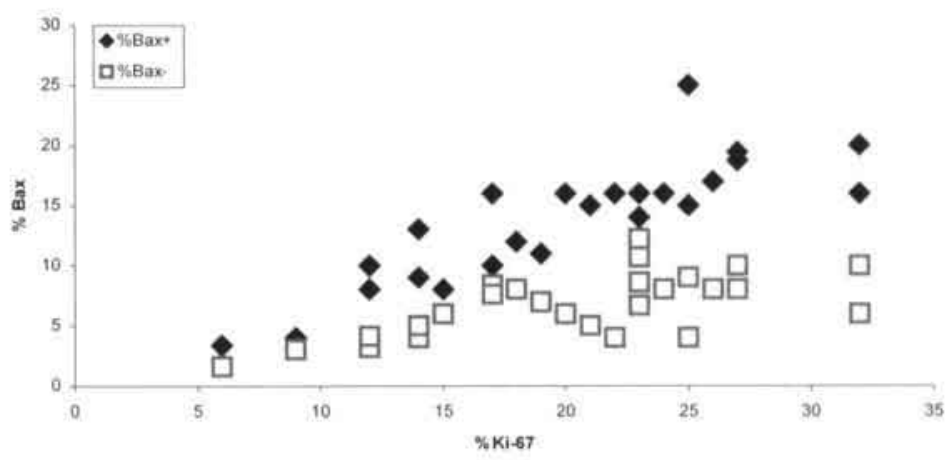

Figure 4: Bax status of the proliferative compartment

The graph represents the percentage of Bax positive and negative cells within the $\mathrm{Ki}-67$ positive fraction. From this graph it can be seen that, in the proliferative compartment of each individual tumor the percentage of Bax positive cells is higher than the percentage of Bax negative cells. 
Table 3: Frequency of expression of proliferation- and apoptosis markers in BCC

\begin{tabular}{|c|c|c|c|c|c|}
\hline Subtype & $\begin{array}{l}\text { Patient } \\
\text { number }\end{array}$ & $\mathrm{Ki}-67+$ & Bax + & $\mathrm{Ki}-67+/ \mathrm{Bax}-$ & $\mathrm{Ki}-67+/ \mathrm{Bax}+$ \\
\hline $\begin{array}{l}\text { Nodular } \\
\text { Nodular }\end{array}$ & $\begin{array}{l}1 \\
2\end{array}$ & $\begin{array}{l}9 \% \\
19 \%\end{array}$ & $\begin{array}{l}82 \% \\
87 \%\end{array}$ & $\begin{array}{l}3 \% \\
7 \%\end{array}$ & $\begin{array}{l}4 \% \\
11 \%\end{array}$ \\
\hline Nodular & 3 & $27 \%$ & $85 \%$ & $10 \%$ & $19 \%$ \\
\hline Nodular & 4 & $26 \%$ & $83 \%$ & $8 \%$ & $17 \%$ \\
\hline Nodular & 5 & $22 \%$ & $74 \%$ & $4 \%$ & $16 \%$ \\
\hline Nodular & 6 & $6 \%$ & $77 \%$ & $2 \%$ & $3 \%$ \\
\hline Nodular & 7 & $17 \%$ & $82 \%$ & $8 \%$ & $10 \%$ \\
\hline Nodular & 8 & $24 \%$ & $82 \%$ & $8 \%$ & $16 \%$ \\
\hline Nodular & 9 & $23 \%$ & $87 \%$ & $7 \%$ & $16 \%$ \\
\hline Nodular & 10 & $25 \%$ & $80 \%$ & $9 \%$ & $15 \%$ \\
\hline Nodular & 11 & $8 \%$ & $70 \%$ & $3 \%$ & $5 \%$ \\
\hline Nodular & 12 & $27 \%$ & $82 \%$ & $4 \%$ & $21 \%$ \\
\hline Nod/morph & 13 & $21 \%$ & $87 \%$ & $5 \%$ & $15 \%$ \\
\hline Nod/morph & 14 & $14 \%$ & $81 \%$ & $4 \%$ & $13 \%$ \\
\hline Nod/aden & 15 & $23 \%$ & $67 \%$ & $12 \%$ & $12 \%$ \\
\hline Nod/aden & 16 & $23 \%$ & $77 \%$ & $8 \%$ & $14 \%$ \\
\hline Morphea & 17 & $32 \%$ & $83 \%$ & $10 \%$ & $20 \%$ \\
\hline Mnod/morph & 18 & $25 \%$ & $60 \%$ & $4 \%$ & $25 \%$ \\
\hline Mnod/morph & 19 & $32 \%$ & $72 \%$ & $6 \%$ & $16 \%$ \\
\hline Mnod/morph & 20 & $20 \%$ & $78 \%$ & $6 \%$ & $16 \%$ \\
\hline Mnod/morph & 21 & $14 \%$ & $79 \%$ & $5 \%$ & $9 \%$ \\
\hline Mnod/morph & 22 & $27 \%$ & $80 \%$ & $8 \%$ & $19 \%$ \\
\hline Mnod/morph & 23 & $22 \%$ & $79 \%$ & $4 \%$ & $19 \%$ \\
\hline Micronodular & 24 & $12 \%$ & $88 \%$ & $3 \%$ & $10 \%$ \\
\hline Micronodular & 25 & $15 \%$ & $79 \%$ & $6 \%$ & $8 \%$ \\
\hline Micronodular & 26 & $14 \%$ & $87 \%$ & $5 \%$ & $8 \%$ \\
\hline Mixed & 27 & $23 \%$ & $65 \%$ & $11 \%$ & $12 \%$ \\
\hline Mixed & 28 & $18 \%$ & $76 \%$ & $8 \%$ & $12 \%$ \\
\hline Mixed & 29 & $12 \%$ & $88 \%$ & $4 \%$ & $8 \%$ \\
\hline Mixed & 30 & $17 \%$ & $77 \%$ & $8 \%$ & $16 \%$ \\
\hline Mean \% & & $19.7 \%$ & $80.1 \%$ & $6.4 \%$ & $13.0 \%$ \\
\hline SD & & $6.8 \%$ & $7.0 \%$ & $2.6 \%$ & $5.2 \%$ \\
\hline
\end{tabular}

Abbreviation: Nod $/$ morph $=$ nodular $/$ morpheaform, Nod $/$ aden $=$ nodular/adenoid $\mathrm{Mnod} / \mathrm{morph}=$ micronodular $/$ morpheaform, $\mathrm{SD}=$ standard deviation 
Based on the different percentages of cells staining positive for the three markers we can distinguish three different tumor cell fractions (Table 4). The progressive fraction, which stains positive for $\mathrm{Bcl}-2$ and $\mathrm{Ki}-67$, but is negative for Bax, accounts for $6.4 \pm 2.6 \%$ of the tumor cells. This fraction of cells may be thought of as being responsible for the growth of the tumor since it is actively proliferating and protected from undergoing apoptosis. The fraction of cells that expresses all three markers may be regarded upon as proliferating but still prone to apoptosis because of the presence of Bax. This fraction comprises $13.0 \pm 5.2 \%$ of the tumor cells. The third fraction $(47 \pm 6.2 \%)$, expressing Bax and $\mathrm{Bcl}-2$, but lacking expression of $\mathrm{Ki}-67$, is the non-proliferating fraction that is still prone to apoptosis.

Table 4: Frequency of different cell populations in BCC

\begin{tabular}{lll}
\hline Cell fraction & Marker pattern & Percentage \\
\hline Progressive & $\mathrm{Bcl}-2+/ \mathrm{Ki}-67+/ \mathrm{Bax}-$ & $6,4 \pm 2,6$ \\
Proliferative, prone to apoptosis & $\mathrm{Bcl}-2+/ \mathrm{Ki}-67+/ \mathrm{Bax}+$ & $13,0 \pm 5,2$ \\
Non-proliferative,prone to apoptosis & $\mathrm{Bcl}-2+/ \mathrm{Ki}-67-/ \mathrm{Bax}+$ & $47,6 \pm 6,2$ \\
\hline
\end{tabular}

\section{Discussion}

The growth rate in neoplastic lesions is often determined by both an increase in the fraction of proliferating cells, as well as a decrease in the rate of cell loss ${ }^{14}$. It has become apparent that in BCC an imbalance between apoptosis and proliferation may explain its progression. Candidates for regulating the rate of cell death are $\mathrm{Bcl}-2$, which prevents apoptosis ${ }^{15-19}$, and Bax, which is known to induce apoptosis ${ }^{18.20}$. These two proteins can form homo-dimers and heterodimers, and their balance eventually determines whether the process of apoptosis is induced or suppressed ${ }^{10}$. To detect cell proliferation, Ki-67 antibodies are most widely used. They bind to a nuclear antigen expressed by cycling cells ${ }^{21,22}$.

Our results in normal skin are in concert with previously described studies, showing Bcl-2 expression in the basal layer, Ki-67 expression in the parabasal layer and Bax staining in a few basal cells, but predominantly in the suprabasal layers $^{23,24}$. Our double-label immuno-assays clearly demonstrated the almost exclusive staining patterns for $\mathrm{Ki}-67$ and $\mathrm{Bcl}-2$ on the one hand, and for $\mathrm{Bcl}-2$ and Bax on the other. A few cells, which are most likely responsible for the regeneration of the epidermis, expressed both $\mathrm{Ki}-67$ and $\mathrm{Bcl}-2$. The expression of Bax in the suprabasal compartment may reflect the commitment of these cells to undergo terminal differentiation and eventually apoptosis, which also explains the downregulation of $\mathrm{Bcl}-2$ in these cells.

The expression of these markers in the epidermis overlying BCC has not been studied extensively before. Our results showed Bax expression comparable with that in normal epidermis, but expanded staining with the polyclonal $\mathrm{Bcl}-2$ antibody in the epidermis overlying BCC. The differences in staining patterns obtained by the monoclonal and polyclonal $\mathrm{Bcl}-2$ antibodies may be explained 
by the recognition of different epitopes. The epitope recognized by the monoclonal $\mathrm{Bcl}-2$ antibody is apparently shielded in the suprabasal cell layers by heterodimerization of $\mathrm{Bcl}-2$ with other proteins, for example Bax. Similar observations of epitope shielding have been described by Schandl et $\mathrm{al}^{25}$.

The fraction of parabasal cells staining for $\mathrm{Ki}-67$ was increased in the epidermis overlying BCC as compared with that in the epidermis of normal skin, while also more suprabasally located cells were $\mathrm{Ki}-67$ positive. This suggests loss of cell cycle control and maintenance of the $\mathrm{Bcl}-2 / \mathrm{Bax}$ status in the process of migration of basal cells towards the suprabasal layer in the epidermis overlying BCC. A significantly increased $\mathrm{Ki}-67$ expression was also detected in the hyperplastic epidermis overlying a keratotic melanocytic nevus, whereas $\mathrm{Bcl}-2$ and Bax were expressed similarly in both normal and hyperplastic epidermis ${ }^{26}$. This demonstrates increased proliferation in the context of adequately regulated apoptosis.

A similar mechanism may explain the phenotype of $B C C$, in which a cell fraction occurs which express both $\mathrm{Bcl}-2$ and $\mathrm{Ki}-67$, thus representing the actively proliferating fraction. The percentage of these cells, which are double positive for $\mathrm{Ki}-67$ and $\mathrm{Bcl}-2$, varied widely between tumors (6-32\%) and also within the individual tumors. A correlation between the histological type of the tumor and the percentage of Ki-67 positive cells could not be found. Nevertheless, it may be obvious that these double-positive cells play a key role in the progression of the tumor, one reason being that they are prone to accumulation of genetic modifications.

A comparison between the growth behavior of trichoepithelioma (TE), a benign cutaneous tumor that originates from hair follicles ${ }^{27}$, and BCC shows that BCC and TE exhibit both differences in $\mathrm{Ki}-67$ and $\mathrm{Bcl}-2$ expression ${ }^{28,29}$. TE is a tumor characterized by proliferation of keratinocytes that rapidly differentiate into mature follicular cells, and which apparently cease to express Bcl-2. BCC is composed of a population of basaloid keratinocytes, which largely retain their ability to produce $\mathrm{Bcl}-2^{29}$. Furthermore, the number of $\mathrm{Ki}-67$ expressing cells is significantly higher in $\mathrm{BCC}^{28}$, which may explain the differences in growth behavior between these tumors. The consistent lack of expression of Bcl-2 in squamous cell carcinoma (SCC), a common malignant neoplasm that arises in the skin, contrasts with the staining seen in BCCs and suggests that these malignancies do not share the same cells of origin. Furthermore, their difference in expression of $\mathrm{Bcl}-2$ reflects their difference in regulation of cell turnover ${ }^{30}$.

In BCC cells, a variable Bax expression pattern was found. The relatively large fraction of the cells expressing Bax in the tumor seems rather unexpected because this protein is known to act as a tumor suppressor by enabling cell loss through apoptosis10. Previous studies on the expression of Bax in BCC described conflicting results. Rossen et $a l^{31}$ showed that the protein is not expressed in BCC, whereas Delehedde et $a^{23}$ demonstrated that the Bax protein is in fact expressed in BCC. We found an expression pattern similar to that of Delehedde et $a l^{23}$, using the same antibody as used by Rossen et $a l^{25}$. However, we used frozen tissue sections, while these authors used paraffin embedded material, which may explain the different results.

It was shown in previous studies ${ }^{6,32,33}$ that, based on morphology, the frequency of apoptotic cells in different types of BCC ranged from $0.6 \%$ to $51 \%$. This corroborates our findings that approximately $80 \%$ of the BCC cells express Bax 
and is therefore prone to apoptosis. This relatively high percentage of Bax expressing cells, combined with the relatively low fraction of the cells expressing both $\mathrm{Ki}-67$ and $\mathrm{Bcl}-2$, may explain the slow progression rate of $\mathrm{BCC}$. In line with our finding that a relatively large proportion of the BCC cells express the Bax protein, Mooney et $a^{\hat{\beta}}$ described that the apoptosis: mitosis ratio for $\mathrm{BCC}$ was found to be 15.1 , as compared to 2.1 for melanoma. Although the finding by several authors that up to $50 \%$ of the BCC cells can be apoptotic ${ }^{6.26 .27}$, is now explained by the high percentages of cells expressing Bax. The question remains whether $\mathrm{Bcl}-2$ is still functional. Previous studies already mentioned $\mathrm{Bcl}-2$ mutations. Huang et $\mathrm{al}^{34}$ showed that, when the serine residue at position 70 of the $\mathrm{Bcl}-2$ protein is altered into an alanine residue, the anti-apoptosis function of the protein is diminished because the protein cannot be dephosphorylated. Other inactivating mutations were deletion of the conserved $\mathrm{BH} 4$ domain, as well as $\mathrm{G} 145 \mathrm{E}$ and W188A mutations 34 . Furthermore, Uhlmann et $a^{35}$ showed that the deletion of a non-conserved region between residues 51 and 85 of human $\mathrm{Bcl}-2$ resulted in an enhanced interaction with the death-promoting protein Bax, but no correlation with the ability of Bcl-2 to interact with other proteins was observed.

In summary we can state that the results of our study show a relatively small progressive cell fraction in BCC that is protected from apoptosis and actively proliferating. The failure of these cancer cells to undergo programmed cell death may contribute substantially to tumor progression. It has however also become clear that a relatively high percentage of BCC cells express considerable levels of Bax, a pro-apoptotic protein. In particular the presence of this component in BCC may explain its indolent growth behavior.

\section{Acknowledgements}

The authors would like to thank Dr. Gertruud Krekels, Dr. Judith Ostertag and Nicole Smeets of the Department of Dermatology and the Department of Plastic Surgery at the University Hospital Maastricht for providing BCC specimens and normal skin preparations. Furthermore, we acknowledge the assistance of Mieke Henfling and Helma Kuijpers of the Department of Molecular Cell Biology \& Genetics in the immunoblotting studies. 


\section{References}

1. Jacobs $\mathrm{GH}$, Rippey JJ, Altini M. Prediction of aggressive behavior in basal cell carcinoma. Cancer 1982;49:533-537.

2. Bartek J, Lukas J, Bartkova J. Perspective: Defects in cell cycle control and cancer. J. Pathol. 1999;187:95-99.

3. Weinstein GD, Frost P. Cell proliferation in human basal cell carcinoma. Cancer Res. 1970;30:724-728.

4. Heenen M, Achten G, Galand P. Autoradiographic analysis of cell kinetics in human normal epidermis and basal cell carcinoma. Cancer Res. 1973;33:123127.

5. Grimwood RE, Ferris CF, Mercill DB, Huff JC. Proliferating cells of human basal cell carcinoma are located on the periphery of tumor nodules. J. Invest. Dermatol. 1986;86:191-194.

6. Mooney EE, Ruis Peris JM, O'Neill A, Sweeney EC. Apoptotic and mitotic indexes in malignant melanoma and basal cell carcinoma. J. Clin. Pathol. 1995;48:242-244.

7. Tsujimoto $\mathrm{Y}$, Finger LR, Yunis J, Nowell PC, Croce CM. Cloning of the chromosome breakpoint of neoplastic $B$ cells with the $t(14: 18)$ chromosome translocation. Science 1984;226:1097-1099.

8. Cleary ML, Smith SD, Sklar J. Cloning and structural analysis of cDNAs for Bcl2 and a hybrid bcl-2/immunoglobulin transcript resulting from the $t(14: 18)$ translocation. Cell 1986;47:19-28.

9. Reed JC. Bcl-2 and the regulation of programmed cell death. J. Cell Biol. 1994;124:1-6.

10. Oltvai ZN, Milliman CL, Korsmeyer SJ. Bcl-2 heterodimerizes in vivo with a conserved homolog, Bax, that accelerates programmed cell death. Cell 1993;74:609-619.

11. Broers JLV, Machiels BM, Van Eijs GJJM, Kuijpers HJH, Van Driel R, Ramaekers FCS. Dynamics of the nuclear lamina as monitored by GFP-tagged A-type lamins. J. Cell Sci. 1999;112:3463-3475.

12. Adams JC. Biotin amplification of biotin and horseradish peroxidase signals in histochemical stains. J. Histochem. Cytochem. 1992;40(10):1457-1463.

13. Speel EJM, Ramaekers FCS, Hopman AHN. Sensitive multicolor fluorescence in situ hybridization using catalyzed reporter deposition (CARD) amplification. J. Histochem. Cytochem. 1997;45:1439-1446.

14. Baserga R. The biology of cell reproduction. 1985.

15. Chen-Levy Z, Nourse J, Cleary ML. The bcl-2 candidate proto-oncogene product is a 24-KiloDalton integral-membrane protein highly expressed in lymphoid cell lines and lymphomas carrying the $t(14 ; 18)$ translocation. Mol. Cell. Biol. 1989;9(2):701-710.

16. Hawkins CJ, Vaux DL. Analysis of the role of bcl-2 in apoptosis. Immunol. Rev. 1994;142(127-139).

17. Hockenbery D, Nunez G, Milliman C, Schreiber RD, Korsmeyer SJ. Bcl-2 is an inner mitochondrial membrane protein that blocks programmed cell death. Nature 1990:348:334-336.

18. Korsmeyer SJ. Bcl-2 initiates a new category of oncogenes:regulators of cell death. Blood 1992;80(4):879-886.

19. Kroemer $\mathrm{G}$. The proto-oncogene bcl-2 and its role in regulating apoptosis. Nat. Med. 1997;3(6):614-620.

20. Reed JC. Double identity for proteins of the bcl-2 family. Nature 1997:387:773776.

21. Sawhney N, Hall PA. Ki67-Structure, function and new antibodies, J. Pathol. 1992:168:161-162. 
22. Verheijen R, Kuijpers HJH, van Driel R, Beck JLM, van Dierendonck JH, Brakenhoff GJ, et al. Ki-67 detects a nuclaer matrix-associated proliferationrelated antigen. II. Localization in mitotic cells and association with chromosomes. J. Cell Sci. 1989;92:531-540.

23. Delehedde M, Cho SH, Sarkiss M, Brisbay S, Davies M, El-Nagar AK, et al. Altered expression of bcl-2 family member proteins in nonmelanoma skin cancer. Cancer 1999;85:1514-1522.

24. Matsuta M, Kimura S, Kosegawa G, Kon S, Matsuta M. Immunohistochemical detection of ki-67 in epithelial skin tumors in formalin-fixed paraffin-embedded tissue sections using a new monoclonal antibody (MIB-1). J. Dermatol. 1996;23:147-152.

25. SchandI CA, Li S, Re GG, Fan W, Willingham MC. Mitotic chromosomal Bcl-2:II Localization to interphase nuclei. J. Histochem. Cytochem. 1999.

26. Horenstein MG, Prieto VG, Burchette JL, Shea CR. Keratotic melanocytic nevus: a clinicopathologic and immunohistochemical study. J Cutan Pathol 2000;27:344-350.

27. Matt D, Xin H, Vortmeyer AO, Zhuang Z, Burg G, Boni R. Sporadic trichoepithelioma demonstrates deletions at 9q22.3. Arch. Dermatol. 2000;136 (5):657-660.

28. Abdelsayed RA, Guijarro-Rojas M, Ibrahim NA, Sangueza OP. Immunohistochemical evaluation of basal cell carcinoma and trichepithelioma using Bcl-2, Ki67, PCNA and P53. J Cutan Pathol 2000;27:169-175.

29. Smoller BR, Van de Rijn M, LeBrun D, Warnke RA. Bcl-2 expression reliably distinguishes trichoepitheliomas from basal cell carcinomas. $\mathrm{Br}$. J. Dermatol. 1994;131:28-31.

30. Morales-Ducret JCR, Van de Rijn M, LeBrun DP, Smoller BR. Bcl-2 expression in primary malignancies of the skin. Arch. Dermatol. 1995;131:909-912.

31. Rossen K, Karabulut Thorup A, Hou-Jensen K, Krag Jacobsen G. Bax protein is not expressed by basal cell carcinomas. Br. J. Dermatol. 1998;139:472-474.

32. Staibano S, Lo Muzio L, Mezza E, Argenziano G, Tornillo L, Pannone G, et al. Prognostic valua of apoptotic index in cutaneous basal cell carcinomas of head and neck. Oral Oncology 1999;35:541-547.

33. Wikonkal NM, Berg RJW, van Haselen CW, Horkay I, Remenyik E, Begany A, et al. Bcl-2 versus p53 protein expression and apoptotic rate in human nonmelanoma skin cancers. Arch. Dermatol 1997;133:599-602.

34. Huang DCS, O'Reilly LA, Strasser A, Cory S. The anti-apoptosis function of bcl2 can be genetically separated from its inhibitory effect on cell cycle entry. EMBO J. 1997;16(15):4628-4638.

35. Uhlmann EJ, D'Sa-Eipper C, Subramanian T, Wagner AJ, Hay N, Chinnadurai G. Deletion of a nonconserved region of bcl-2 confers a novel gain of function: Suppression of apoptosis with concomitant cell proliferation. Cancer Res. 1996;56:2506-2509. 



\title{
3.2: Expression of pro- and anti-apoptotic members of the $\mathrm{Bcl}-2$ family and associated proteins in normal human skin and basal cell carcinoma
}

\author{
CMLJ Tilli ${ }^{1,2}$, HAM Neumann ${ }^{3}$, FCS Ramaekers ${ }^{2}$
}

Research Institute Growth \& Development, University Maastricht, The Netherlands

1 Dept. of Dermatology, University Hospital Maastricht, The Netherlands

2 Dept. of Molecular Cell Biology, University Maastricht, The Netherlands

3 Dept. of Dermatology \& Venereology, Erasmus University Rotterdam, The Netherlands 


\section{Abstract}

\section{Background}

Programmed cell death (apoptosis) is an important step in tissue homeostasis, with members of the $\mathrm{Bcl}-2$ protein family regulating this process. The delicate balance between pro- and anti-apoptotic members of this family is disturbed in several cancers.

\section{Methods}

Expression of the pro-apoptotic proteins Bid, Bad and Bcl-xs, activated caspase-3, and the anti-apoptotic proteins Bag-1, Bcl-xl and 136SerP-Bad, and two 14-3-3 variants known to interact with 136SerP-Bad, were immunohistochemically studied in normal skin and basal cell carcinoma (BCC), as well as in the apparently normal epidermis overlying BCC.

\section{Results}

In normal skin the basal layer of the epidermis stained homogeneously positive for Bag-1, Bcl-xs, Bcl-xl, Bid and Bad, whereas the suprabasal cell layers remained negative for $\mathrm{Bag}-1, \mathrm{Bcl}-\mathrm{xS}$ and $\mathrm{Bid}$, while $\mathrm{Bcl}-\mathrm{xl}$ and $\mathrm{Bad}$ were present in the entire epidermis. 136SerP-Bad and cleaved caspase-3 showed a scattered suprabasal pattern of expression in normal epidermis. $14-3-3 \varepsilon$ showed a homogeneous expression pattern in the entire epidermis, while 14-3$3 \sigma$ was absent from the basal cell layer. The majority of tumors showed homogeneous cytoplasmic staining for Bag-1, Bcl-xs, Bcl-xl, Bid and Bad, whereas 136 SerP-Bad was found in less than $10 \%$ of the tumor cells in all cases and cleaved caspase- 3 in less than $5 \% .14-3-3 \varepsilon$ was homogeneously

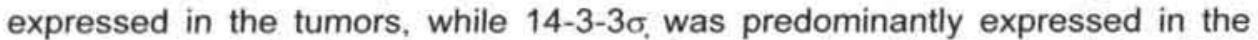
central part of the tumors. The apparently normal epidermis overlying BCC showed enhanced expression patterns for Bcl-xs, Bid, Bag-1 and 14-3-3б.

The low frequency of tumor cells showing activated caspase- 3 was often found to be localized in the central part of BCC tumor nests, which was mutually exclusive with 136SerP-Bad which was found to be expressed in the periphery of these tumor areas.

\section{Conclusion}

The pro- and anti-apoptotic markers studied show comparable patterns of expression in the basal cell layer of normal epidermis and in BCC. In the apparently normal epidermis overlying BCC, differences were seen in expression patterns as compared to normal epidermis. This altered expression may reflect a role of these constituents in the pathogenesis of BCC.

The presence of anti-apoptotic 136SerP-Bad positive cells in the peripheral cell layers of tumor areas may be the result of growth stimulating effect on these cells by surrounding survival factors. The central cells of these tumor nests are largely devoid of these factors and are therefore subject to apoptosis as indicated by caspase- 3 activation .

Keywords: apoptosis, basal cell carcinoma, Bcl-2 family 


\section{Introduction}

The disturbance of the delicate balance between cell proliferation and cell death, necessary for normal development and tissue homeostasis, may result in development and progression of cancer ${ }^{1,2}$. We have recently reported a imbalance between cell death and cell proliferation in basal cell carcinoma (BCC) based on the immunohistochemical staining results for the anti-apoptotic $\mathrm{Bcl}-2$ protein, the pro-apoptotic Bax protein and the proliferation marker $\mathrm{Ki}-67^{3}$. The study furthermore identified a small progressive cell population in BCC, which could explain its indolent growth behavior. However, in recent years, a large number of $\mathrm{Bcl}-2$ related proteins have been isolated that serve as critical regulators of apoptosis, acting either to inhibit or to promote cell death ${ }^{4.5}$. This family of proteins can be subdivided into three categories.

The first category consists of the anti-apoptotic members such as $\mathrm{Bcl}-2^{6}$ and $B \mathrm{BCl}-\mathrm{Xl}^{7}$ that share homology in four $\mathrm{Bcl}-2$ sequence homology $(\mathrm{BH})$ regions ${ }^{8.9}$, i.e. $\mathrm{BH} 1$ to $\mathrm{BH}^{8}{ }^{8}$. The second category consists of pro-apoptotic members, such as Bax10 and Bak11 that share sequence homology in $\mathrm{BH} 1$ to $\mathrm{BH} 3$, but not in $\mathrm{BH}$. The third category comprises the 'BH3-only proteins', such as Bim ${ }^{12}, \mathrm{Bid}^{13}$ and $\mathrm{Bad}^{14}$, all with a pro-apoptotic activity ${ }^{15}$. Heterodimerization between these anti- and pro-apoptotic family members can occur ${ }^{16-18}$. The balance in the expression of Bcl-2 family members is an important determinant of the cells' fate. Furthermore, modification of the Bcl-2 family members, e.g. by phosphorylation, dephosphorylation or cleavage by activated caspases will determine their functional properties. Bad can become phosphorylated under the influence of several growth factors, upon which the protein interacts with 143-3 proteins and remains inactive in the cytosol ${ }^{19}$. Bid becomes cleaved by activated caspase $-8^{20}$ upon which the C-terminal fragment can translocate to the mitochondria to induce cytochrome $\mathrm{C}$ release ${ }^{21}$. Another protein associated with prolonged cell survival is Bag-1, which can bind to Bcl-2, enhancing its antiapoptotic effect ${ }^{22}$. The potential contribution of these $\mathrm{Bcl}-2$ family members to the pathogenesis of $\mathrm{BCC}$ is still largely unknown, although a possible role in other types of malignancies has been described ${ }^{23-27}$. To examine the potential contribution of these $\mathrm{Bcl}-2$ family members and associated proteins to the pathogenesis of $\mathrm{BCC}$, we immunohistochemically investigated their expression patterns in frozen sections of normal skin, apparently normal epidermis overlying BCC, and 24 cases of this malignancy. An imbalance between these pro- and anti-apoptotic constituents should result in apoptosis in a certain percentage of (tumor) cells. This fraction of cells is estimated using an antibody to activated caspase- 3 , an executioner caspase stimulated via different routes of apoptosis induction ${ }^{28}$.

\section{Materials and Methods}

\section{Tumor samples}

Normal skin biopsies $(n=5)$ were obtained by breast reduction surgery at the Department of Plastic Surgery, and the BCC $(n=24)$ samples were obtained by Mohs' micrographic surgery at the Department of Dermatology of our hospital. 
These specimens comprised 12 cases of the nodular type, 2 cases of the micronodular type, 5 cases of the morphea type, 3 cases of the nodularmorphea type, 1 case of the micronodular-morphea type, and 1 case of the mixed type. The samples were snap frozen in liquid nitrogen and stored at $80^{\circ} \mathrm{C}$ until used. Serial sections $(5 \mu \mathrm{m})$ were cut and placed on 3aminopropyltriethoxysilan (APTS; Sigma-Aldrich Chemie BV, Zwijndrecht, The Netherlands)-coated slides. The histopathologic diagnosis was established using haematoxylin (Fluka AG, Buchs, Germany) and eosin (BDH Laboratory Supplies, Poole UK) staining.

\section{Immunohistochemistry}

After fixation in acetone $\left(-20^{\circ} \mathrm{C}\right)$, the slides were incubated with the primary antibodies, overnight at $4 \mathrm{C}$. Table 1 shows the antibodies used in this study and the dilutions applied. The antibodies were diluted in $1 \%$ bovine serum albumin (BSA; Roche Diagnostics $\mathrm{GmbH}$, Mannheim, Germany) in PBS to block non-specific binding.

The primary antibodies against Bag-1, Bcl-xl, Bcl-xs, 136SerP-Bad, 14-3-3६ and 14-3-3 $\sigma$ were detected with peroxidase-conjugated secondary antibodies depending on the Isotype of the primary antibodies. Peroxidase activity was detected using the chromogen 3,3'-diaminobenzidine (DAB; Sigma-Aldrich Chemie BV, Zwijndrecht, The Netherlands), and the sections were counterstained with haematoxylin. For the detection of Bid further enhancement of the signal was necessary. After incubation with the peroxidase-conjugated secondary antibody, the slides were incubated with biotin-conjugated tyramide (Dupont NEN, Boston, MA, USA), followed by incubation with peroxidaseconjugated avidin (DAKO A/S, Glostrup, Denmark). The peroxidase activity was then detected using $\mathrm{DAB}$ and the slides were counterstained using haematoxylin. Detection of Bad and activated caspase-3 required blocking of aspecific staining prior to incubation with the primary antibody. The slides were incubated using $5 \%$ normal goat serum (NGS)/PBS for 1 hour at room temperature. Following this incubation, the slides are incubated with the primary antibody overnight at $4^{\circ} \mathrm{C}$. After incubation with the secondary antibody, the $A B C$-detection kit was used. The peroxidase activity was then detected using $\mathrm{DAB}$ and the slides were counterstained using haematoxylin. As a negative control for all antibodies, the primary antibodies were omitted.

Evaluation of the frequency of positive cells was as follows: - absence of staining; + $/$ - staining in a small fraction of cells i.e. less than $10 \% ;+$ staining in most tumor cells i.e. more than $75 \%$; ++ homogeneous staining pattern.

\section{Results}

The staining results of the antibodies against Bcl-xs, Bcl-xl, Bid, Bad, 136SerPBad, 14-3-3- $\varepsilon, 14-3-3-\sigma$, Bag-1 and cleaved caspase-3 are summarized in Table 2 and depicted in Fig.1. 
Table 1: Antibody characteristics and their dilutions used in the immunoperoxidase staining procedure

\section{Antibody}

Bad, polyclonal IgG

136SerP-Bad, polyclonal lgG

Bag-1, polyclonal IgG

Bcl-xl, monoclonal lgG2a

$\mathrm{Bcl}-\mathrm{xs}$, rabbit polyclonal IgG

Bid, polyclonal IgG

Activated caspase-3, polyclonal IgG

14-3-3 $\varepsilon$, monoclonal IgM

$14-3-3 \sigma$ monoclonal lgG1
Manufacturer

Cell Signaling Technology, Beverly, MA,USA

Dilution

Santa Cruz Biotechnology Inc., Santa Cruz, CA, USA 1:50

Santa Cruz Biotechnology Inc., Santa Cruz, CA,USA 1:200

Zymed Laboratories Inc., San Francisco, CA,USA 1:50

Oncogene Research Products, Cambridge, MA,USA 1:25

Santa Cruz Biotechnology Inc., Santa Cruz, CA, USA 1:100

Cell Signaling Technology, Beverly, MA,USA

$1: 50$

BD Transduction Laboratories, Heidelberg, Germany 1:250

Biocarta, San Diego, CA,USA

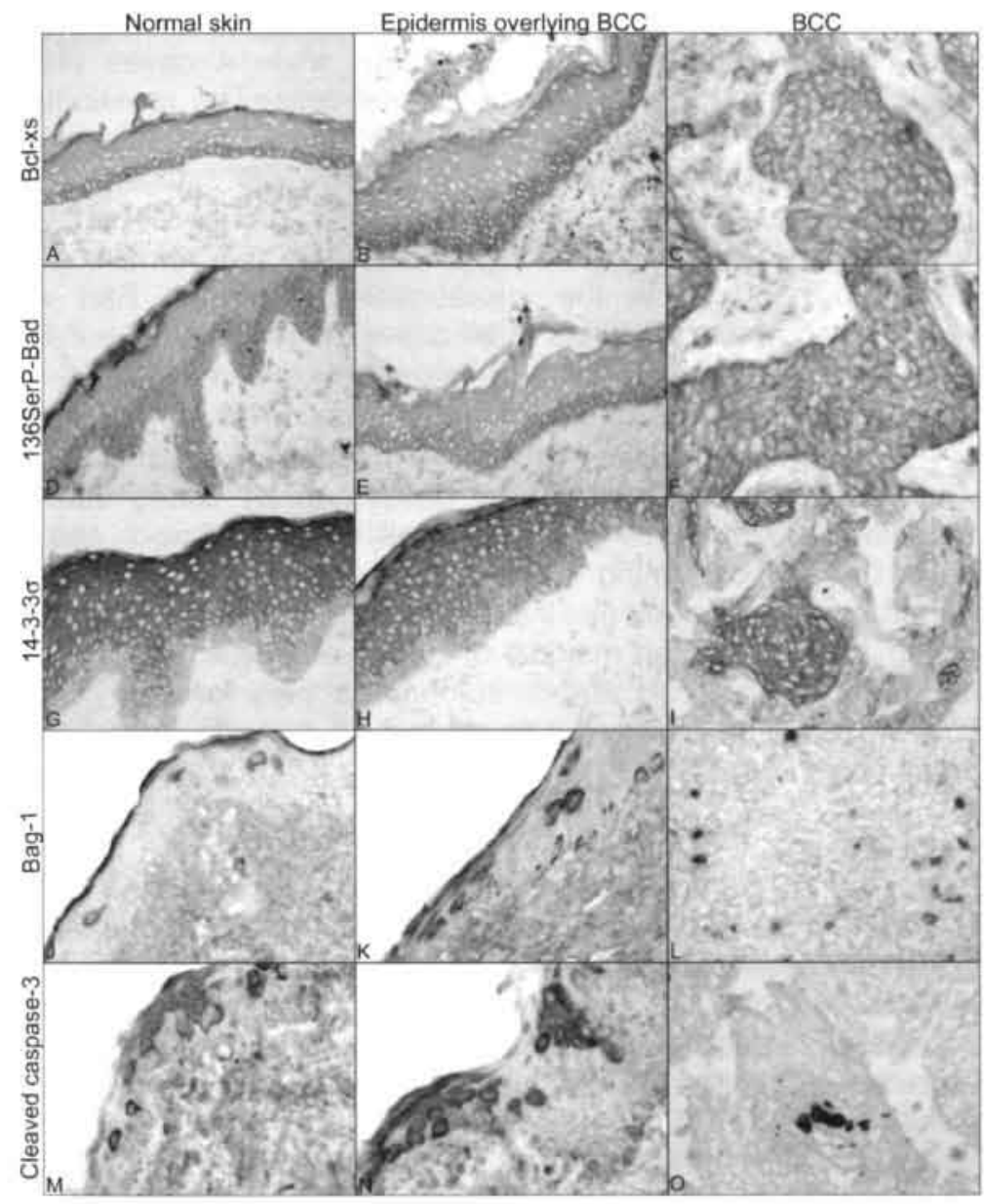

Figure 1: Expression patterns of pro- and anti-apoptotic members of the Bcl-2 family and associated proteins in skin and BCC. Original magnifications used for images $A, B, D, E, G$ $\mathrm{K}, \mathrm{M}-\mathrm{O} 20 \mathrm{x}$, images C,F,L 40x. 


\section{Normal skin}

In normal skin, the basal cell layer of the epidermis stained homogeneously positive for Bcl-xs (Fig.1A), Bcl-xl, Bid, Bad, 14-3-3- $\varepsilon$ and Bag-1 (Fig.1J), whereas the suprabasal cell layers remained negative for Bcl-xs, Bid and Bag1. while Bcl-xl, Bad and 14-3-3- $\varepsilon$ were expressed homogeneously in the suprabasal cell layers. 136SerP-Bad (Fig.1D) was detected in a small fraction of cells in the epidermis, as was cleaved caspase-3 (Fig.1M). 14-3-3- $\sigma$ (Fig.1G) was negative or present only in a small fraction of basal cells, but homogeneously expressed in the suprabasal cells.

\section{Epidermis overlying BCC}

Bcl-xs stained homogeneously positive in the basal layer of the epidermis overlying BCC in all of the 24 cases and was homogeneously positive in the suprabasal layers in 9 of the 24 cases (38\%). Further 9 cases showed positive staining in the majority of suprabasal cells (Fig.1B), while 4 cases $(17 \%)$ showed occasional immunoreactivity in the suprabasal cells. The remaining 2 cases $(8 \%)$ remained negative in the suprabasal layers. Bcl-xl stained the entire epidermis homogeneously positive in all 24 cases. Bid staining was homogeneous in the basal cell layer of all 24 cases, 10 cases $(42 \%)$ showed occasional immunoreactivity in the suprabasal cells, while the remaining 14 cases $(58 \%)$ remained negative in the suprabasal cell layers. Bad was homogeneously expressed in all cell layers in all cases, whereas 136SerP-Bad (Fig.1E) was present in only a small fraction of epidermal cells in all cases. 14$3-3-\varepsilon$. was homogeneously expressed in the entire epidermis in all cases, whereas $14-3-3-\sigma$. (Fig. $1 \mathrm{H}$ ) is expressed in a small fraction of basal cells but homogeneously in the suprabasal cells in all cases. All 24 cases showed homogeneous cytoplasmic staining of the basal cell layer for Bag-1 and 10 cases $(42 \%)$ showed negative staining in the suprabasal layers. However, 5 cases $(21 \%)$ stained homogeneously positive in the suprabasal cell layers and 5 cases showed Bag-1 staining in the majority of suprabasal cells (Fig. $1 \mathrm{~K}$ ). The remaining 4 cases (17\%) showed occasional immunoreactivity for Bag-1 in the suprabasal cell layers. Cleaved caspase- 3 is expressed in a small fraction of epidermal cells in all cases (Fig.1N).

\section{Basal cell carcinoma}

$\mathrm{Bcl}-\mathrm{xs}$ staining resulted in a homogeneous cytoplasmic staining all BCCs studied (Fig.1C). Staining for Bcl-xl resulted in a homogeneous cytoplasmic staining in 19 of the 24 cases $(79 \%), 2$ cases $(8 \%)$ showed partial positivity in some fields and homogenous staining in other fields, while one case showed only occasional positive staining in cells mainly located in the center of the tumor, and 2 cases remained negative. Bid staining resulted in a homogeneous cytoplasmic staining in 22 of the 24 cases (92\%), while the remaining 2 cases showed either partial positivity, or a combination with a homogeneous staining in some fields. Bad was homogeneously detected in 18 cases (75\%), while 6 cases showed immunoreactivity in the majority of cells. In contrast, 136SerPBad immunopositivity was detected in a small fraction $(<10 \%)$ of the tumor cells (Fig.1F) in the majority of cases $(71 \%)$, whereas the remaining tumors showed no expression of 136 SerP-Bad. 14-3-3- $\varepsilon_{\text {w }}$ was homogeneously expressed in all 
cases, whereas 14-3-3- $\sigma$ was present in the majority of tumor cells, predominantly located in the center of the tumor nests (Fig.1I) in all cases. Bag1 staining of the BCCs resulted in a homogeneous cytoplasmic staining (Fig. 1L) in 23 of the 24 cases (96\%), 1 case showing partial positivity in some fields and homogeneous staining in other fields. Cleaved caspase- 3 was detected in a small fraction of tumor cells (approximately $5 \%$ ) in all cases (Fig.10) and was often predominantly located in the central part of the tumor nests.

Table 2: Expression patterns of pro- and anti-apoptotic members of the Bcl-2 family and associated proteins in skin and BCC

\begin{tabular}{|c|c|c|c|c|c|c|c|c|c|c|}
\hline & & $\begin{array}{c}\text { Bcl-xs } \\
\text { pro }\end{array}$ & $\begin{array}{c}\text { Bcl-xl } \\
\text { anti }\end{array}$ & $\begin{array}{l}\text { Bid } \\
\text { pro }\end{array}$ & $\begin{array}{l}\text { Bad } \\
\text { pro }\end{array}$ & $\begin{array}{c}\text { P-Bad } \\
\text { anti }\end{array}$ & $14-3 \cdot 3^{\varepsilon}$ & $14-3 \cdot 3 \sigma$ & $\begin{array}{c}\text { Bag-1 } \\
\text { anti }\end{array}$ & Capase-3 \\
\hline \multirow[t]{2}{*}{ Normal Skin } & basal cells & $++(5 / 5)$ & $++(5 / 5)$ & $++(5 / 5)$ & $++(5 / 5)$ & $+1-(5 / 5)$ & $H(5 / 5)$ & $\begin{array}{r}-(3 / 5) \\
+1-(2 / 5) \\
\end{array}$ & $t+(5 / 5)$ & $+1 .(5 / 5)$ \\
\hline & suprabasai cells & $\begin{array}{r}-(4 / 5) \\
+*(1 / 5)\end{array}$ & $\begin{array}{r}++(4 / 5) \\
+(1 / 5)\end{array}$ & $-(5 / 5)$ & $\begin{array}{r}++(3 / 5) \\
+(2 / 5)\end{array}$ & $+1-(5 / 5)$ & $+(5 / 5)$ & $++(5 / 5)$ &.$(5 / 5)$ & $+1 \cdot(5 / 5)$ \\
\hline \multirow{2}{*}{$\begin{array}{l}\text { Epidermis overlying } \\
\text { BCC }\end{array}$} & basal cells & $++(24 / 24)$ & $++(24 / 24)$ & $++(24 / 24)$ & $++(24 / 24)$ & $+1-(24 / 24)$ & $+(5 / 5)$ & $+1-(24 / 24)$ & $+\rightarrow(24 / 24)$ & $4 / .(24 / 24)$ \\
\hline & suprabasal cells & $\begin{aligned} &++(9 / 24) \\
&+(9 / 24) \\
&+1-(4 / 24) \\
&-(2 / 24)\end{aligned}$ & $++(24 / 24)$ & \begin{tabular}{|r|}
$-(14 / 24)$ \\
$+/-(10 / 24)$
\end{tabular} & $++(24 / 24)$ & $+1 \cdot(24 / 24)$ & $+(5 / 5)$ & $++(24 / 24)$ & $\begin{array}{r}+(10 / 24) \\
+(5 / 24) \\
+(5 / 24) \\
+F(4 / 24)\end{array}$ & $+1 \cdot(24 / 24)$ \\
\hline$\overline{B C C}$ & tumor cells & $++(24 / 24)$ & $\begin{array}{r}\mid+(19 / 24) \\
+(2 / 24) \\
+f(1 / 24) \\
-(2 / 24)\end{array}$ & $\begin{array}{r}+(22 / 24) \\
+(1 / 24) \\
++-(1 / 24) \\
\end{array}$ & $\begin{array}{r}++(18 / 24) \\
+(6 / 24) \\
\end{array}$ & \begin{tabular}{|r|}
$+1-(17 / 24)$ \\
$-(7 / 24)$
\end{tabular} & $++(24 / 24)$ & $+(24 / 24)$ & $\begin{array}{r}++(23 / 24) \\
+(1 / 24)\end{array}$ & $+7 \cdot(24 / 24)$ \\
\hline $\begin{array}{l}\text { Abbreviations: pro }= \\
\text {; negative } \\
+ \text { + positivity in a small } \\
+; \text { positivity in majority } \\
++ \text {; homogeneousiy po } \\
\text { (xyy): number of positiv }\end{array}$ & $\begin{array}{l}\text { ic protein, ant = ar } \\
\text { cells }<10 \% \\
\% \%\end{array}$ & optotic prote & & & & & $\rightarrow$ & & & \\
\hline
\end{tabular}

\section{Discussion}

The development of cancer is accompanied by disturbances in cell cycle regulation as well as by the suppression of programmed cell death, i.e. apoptosis $^{1}$. In an earlier study ${ }^{3}$ we suggested that in BCC only a small population of tumor cells combines these features. We came to this conclusion on basis of the simultaneous expression of the proliferation marker Ki-67 and the anti-apoptotic $\mathrm{Bcl}-2$ protein, in the absence of the pro-apoptotic Bax protein. The control of apoptosis is, however more complex, involving many more proand anti-apoptotic constituents and associated proteins ${ }^{4.9}$. This study aims at establishing the role of the specific apoptosis-regulating members of the $\mathrm{Bcl}-2$ family and associated proteins in skin carcinogenesis by studying their expression patterns in normal human skin and BCC through immunohistochemical assays. 
As shown in this study a number of pro- and apoptotic members of the Bcl-2 family, i.e. Bag-1, Bcl-xs, Bid and as described before also $\mathrm{Bcl}-2^{3}$ are largely restricted to the basal cell compartment of the normal epidermis. In virtually all BCCs studied, these four constituents were found to be homogeneously expressed and to exhibit a cytoplasmic localization. Thus, the basal cell phenotype with respect to apoptosis regulating proteins is clearly reflected in $\mathrm{BCC}$ by these markers.

High expression of anti-apoptotic Bag-1 protein has in general been correlated with a predisposition for more aggressive behavior of the tumor and less favorable clinical outcome, probably by enhancing the anti-apoptotic activity of $\mathrm{Bcl}-2^{22}$. In oral squamous cell carcinomas, high Bag-1 expression was frequently correlated with nodal metastasis ${ }^{29}$. Furthermore, over-expression of Bag-1 leads to progression of malignant melanoma and promotes metastasis to lung $^{30}$. In patients with invasive breast carcinomas, Bag-1 expression, mainly located at the nucleus, correlated with less favorable clinical outcome ${ }^{31}$. Laryngeal carcinoma patients furthermore showed that nuclear Bag-1 expression correlated with a significantly lower survival rate after radiotherapy ${ }^{32}$. Because of its apparent correlation with highly aggressive behavior, the relatively abundant expression of Bag-1 in BCC is quite surprising since these tumors in general exhibit an indolent clinical behavior. However, in our study Bag-1 showed a cytosolic localization in normal skin as well as in BCC, which may explain this apparent discrepancy.

$\mathrm{Bcl}-\mathrm{xl}$ and $\mathrm{Bcl}-\mathrm{xs}$ are both splice variants of $\mathrm{Bcl}-\mathrm{x}^{7}, \mathrm{Bcl}-\mathrm{xs}$ exerting pro-apoptotic and $\mathrm{BCl}-\mathrm{xl}$ anti-apoptotic effects. Whereas $\mathrm{Bcl}-\mathrm{xs}$ is expressed only in the basal cells of normal skin, Bcl-xl is expressed homogeneously throughout the entire epidermis, and has been shown to be essential for protecting skin and other epithelial cells from apoptosis ${ }^{33}$. Furthermore, it was shown that the Bcl-xl expression level increases from primary melanoma to melanoma-metastases, whereas $\mathrm{Bcl}-\mathrm{xs}$ expression decreases during melanoma progression. This may reflect an increased malignant potential caused by an inhibition of apoptosis and growth advantage for metastatic melanoma cells ${ }^{34}$. In our study, Bcl-xs expression was homogeneous in all BCCs, while 19 of the 24 cases showed also homogeneous expression of $\mathrm{Bcl}-\mathrm{xl}$ in the tumors, indicating a delicate balance between these two Bcl-2 family members.

The pro-apoptotic protein Bid is normally activated by cleavage through caspase-8, after which the C-terminal fragment translocates to the mitochondria where it induces cytochrome $\mathrm{C}$ release ${ }^{20}$. High levels of Bid expression were reported previously in locally advanced prostate cancer ${ }^{23}$, where it was associated with longer recurrence-free survival. It was furthermore stated that the apoptosis-inducing Bid could possibly be of great importance in positive tumor responses to specific chemotherapeutic drugs. These studies and the underlying experiments can however not discriminate between intact Bid and its C-terminal fragment, because of the absence of antibodies specific for the latter.

Furthermore, the enhanced expression of Bag-1 in the suprabasal cell layers of the apparently normal epidermis overlying BCC, as compared to control epidermis, may indicate subtle pre-neoplastic changes that occur in this tissue. A similar result was obtained for $\mathrm{Bcl}-2$ in our earlier study ${ }^{3}$ on $\mathrm{BCC}$. The anti- 
apoptotic effects of Bag-1 and Bcl-2 in this tumor overlying epidermis may however be (partially) compensated for by enhanced expression of proapoptotic Bcl-xs. These findings in skin overlying BCC, with apoptosis regulating proteins typically found in basal cells of normal skin, do however show that this apparently normal epidermis exhibits a phenotype in-between that of normal skin and BCC. A similar conclusion was drawn from studies on the expression of the proliferation marker $\mathrm{Ki}-67$ and of the nuclear A-type lamins ${ }^{35}$.

A remarkable result was found for the expression pattern of 14-3-3 $\sigma$, in the epidermis of normal skin and BCC. In normal skin, the basal cell layer of the epidermis remains negative, a phenomenon also shown by the outer (basal) cell layers of the tumor nests. This supports the earlier hypothesis that the basal cell phenotype is clearly reflected in BCC.

Furthermore, the expression patterns of $136 \mathrm{SerP}-\mathrm{Bad}$ and cleaved caspase- 3 seem to be mutually exclusive in the BCCs we studied. Where cleaved caspase-3 positive cells are mainly located in the central part of the tumor nests, the 136SerP-Bad positivity is predominantly located at the periphery. This suggests, that the presence of surrounding survival factors results in survival and consequent progression of the peripherally located cells, whereas the central cells of these tumor nests are largely devoid from these factors and are therefore subject to apoptosis.

In conclusion we can state, that while BCC shows a remarkable basal cell like phenotype, the epidermis overlying BCC shows a phenotype in between that of normal skin and BCC. Whether this phenomenon is induced by factors generated by the BCC or can be regarded as a first step in skin carcinogenesis remains to be established. Furthermore, the $10 \%$ of tumor cells that are positive for 136SerP-Bad reflect the progressing fraction of the tumors and corroborate our earlier finding that approximately $6 \%$ of the tumor cells represent the progressive fraction ${ }^{3}$. We can thus conclude that several members of the Bcl-2 family indicated that the balance between anti- and pro-apoptotic proteins plays an important role in the progression of BCC. 


\section{References}

1. McDonnell TJ. Cell division versus cell death: a functional model of multistep neoplasia. Mol. Carcinog. 1993;8:209-213.

2. Thompson CB. Apoptosis in the pathogenesis and treatment of disease. Science 1995;267:1456-1462.

3. Tilli CMLJ, Stavast-Kooy AJW, Ramaekers FCS, Neumann HAM. Bax expression and growth behavior of basal cell carcinomas. J. Cutan. Pathol. 2002;29(2):79-87.

4. Gross A, McDonnell TJ, Korsmeyer SJ. Bcl-2 family members and the mitochondria in apoptosis. Genes \& Dev. 1999;13:1899-1911.

5. Cory S. Regulation of lymphocyte survival by the bcl-2 gene family. Annu. Rev. Immunol. 1995;13:513-543.

6. Vaux DL, Cory S, Adams JA. Bcl-2 gene promotes hematopoietic cell survival and cooperates with c-myc to immortalize pre-B cells. Nature $1988 ; 335: 440-$ 442.

7. Boise LH, Gonzalez-Garcia M, Postema CE, Ding L, Lindsten T, Turka LA, et al. Bcl-x, a bcl-2-related gene that functions as a dominant regulator of apoptotic cell death. Cell 1993;74:597-608.

8. Reed JC, Zha H, Aime-Sempe C, Takayama S, Wang HG. Structure-function analysis of $\mathrm{Bcl}-2$ family proteins. Regulators of programmed cell death. Adv Exp Med Biol 1996;406:99-112.

9. Yin XM, Oltvai $\mathrm{ZN}$, Korsmeyer $\mathrm{SJ}$. $\mathrm{BH} 1$ and $\mathrm{BH} 2$ domains of $\mathrm{Bcl}-2$ are required for inhibition of apoptosis and heterodimerization with Bax. Nature 1994;369(6478):321-3.

10. Oltvai ZN, Milliman CL, Korsmeyer SJ. Bcl-2 heterodimerizes in vivo with a conserved homolog, Bax, that accelerates programmed cell death. Cell 1993;74:609-619.

11. Kiefer MC, Brauer MJ, Powers VC, Wu JJ, Umansky SR, Tomei LD, et al. Modulation of apoptosis by the widely distributed $\mathrm{Bcl}-2$ homologue Bak. Nature 1995;374(6524):736-9.

12. O'Connor L, Strasser A, O'Reilly LA, Hausmann G, Adams JM, Cory S, et al. Bim: a novel member of the Bcl-2 family that promotes apoptosis. EMBO J. 1998;17(2):384-395.

13. Wang K, Yin X-M, Chao DT, Milliman CL, Korsmeyer SJ. Bid: a novel BH3 domain-only death agonist. Genes \& Dev. 1996;10:2859-2869.

14. Yang E, Zha J, Jockel J, Boise LH, Thompson CB, Korsmeyer SJ. Bad, a heterodimeric partner for bcl-xl and bcl-2, displaces bax and promotes cell death. Cell 1995;80:285-291.

15. Huang DC, Strasser A. BH3-Only proteins-essential initiators of apoptotic cell death. Cell 2000;103(6):839-42.

16. Sato $\mathrm{T}$, Hanada $\mathrm{M}$, Bodrug $\mathrm{S}$, Irie $\mathrm{S}$, Iwana $\mathrm{N}$, Boise $\mathrm{LH}$, et al, Interactions among members of the $\mathrm{Bcl}-2$ protein family analyzed with a yeast two-hybrid system. Proc. Natl. Acad. Sci. USA 1994;91:9238-9242.

17. Oltvai ZN, Korsmeyer SJ. Checkpoints of dueling dimers foil death wishes. Cell 1994;79(2):189-92.

18. Sedlak TW, Oltvai ZN, Yang E, Wang K, Boise LH, Thompson CB, et al. Multiple Bcl-2 family members demonstrate selective dimerizations with Bax. Proc. Natl. Acad. Sci. USA 1995;92:7834-7838.

19. Tan Y, Demeter MR, Ruan H, Comb MJ. Bad Ser-155 phosphorylation regulates Bad/Bcl-xl interaction and cell survival. J. Biol. Chem. 2000;275(33):25865-25869. 
20. Gross A, Yin XM, Wang K, Wei MC, Jockel J, Milliman CL, et al. Caspase cleaved Bid targets mitochondria and is required for cytochrome c release, while Bcl-xl prevents this release but not Tumor Necrosis Factor-R1/Fas death. J. Biol. Chem. 1999;274(2):1156-1163.

21. Kudla G, Montessuit S, Eskes R, Berrier C, Martinou J-C, Ghazi A, et al. The destabilization of lipid membranes induced by the $\mathrm{C}$-terminal fragment of caspase 8 -cleaved Bid is inhibited by the $\mathrm{N}$-terminal fragment. J. Biol. Chem. 2000;275(30):22713-22718.

22. Takayama S, Sato T, Krajewski S, Kochel K, Irie S, Millan JA, et al. Cloning and functional analysis of BAG-1: a novel Bcl-2-binding protein with anti-cell death activity. Cell 1995;80(2):279-84.

23. Krajewska M, Zapata JM, Meinhold-Heerlein I, Hedayat H, Monks A, Bettendorf $\mathrm{H}$, et al. Expression of bcl-2 family member bid in normal and malignant tissues. Neoplasia 2002;4(2):129-40.

24. Yang $X$, Hao $Y$, Ding $Z$, Pater A, Tang S-C. Differential expression of antiapoptotic gene Bag-1 in human breast normal and cancer cell lines and tissues. Clin. Cancer Res. 1999;5:1816-1822.

25. Turner BC, Krajewski S, Krajewska M, Takayama S, Gumbs AA, Carter D, et al. Bag-1: A novel biomarker predicting long-term survival in early-stage breast cancer. J. Clin. Oncol. 2001;19:992-1000.

26. Schorr K, Li M, Krajewski S, Reed JC, Furth PA. Bcl-2 gene family and related proteins in mammary gland involution and breast cancer. J. Mam. Gland Biol. Neopl. 1999;4(2):153-.

27. Rorke S, Murphy S, Khalifa M, Chernenko G, Tang S-C. Prognostic significance of Bag-1 expression in nonsmall cell lung cancer. Int. J. Cancer 2001;95:317322.

28. Dorstyn L, Kinoshita M, Kumar S. Caspases in cell death. Results Probl Cell Differ 1998;24:1-24.

29. Shindoh M, Adachi M, Higashino F, Yasuda M, Hida K, Nishioka T, et al. Bag-1 expression correlates highly with the malignant potential in early lesions ( $\mathrm{T} 1$ and T2) of oral squamous cell carcinoma. Oral Oncol. 2000;36:444-449.

30. Takaoka A, Adachi M, Okuda H, Sato S, Yawata A, Hinoda Y, et al. Anti-cell death activity promotes pulmonary metastasis of melanoma cells. Oncogene 1997:14:2971-2977.

31. Tang S-C, Shaheta N, Chernenko G, Khalifa M, Wang X. Expression of Bag-1 in invasive breast carcinomas. J. Clin. Oncol. 1999;17:1710-1719.

32. Yamauchi H, Adachi M, Sakata K-I, Hareyama M, Satoh M, Himi T, et al. Nuclear Bag-1 localization and the risk of recurrence after radiation therapy in laryngeal carcinomas. Cancer Lett. 2001;165:103-110.

33. Taylor JK, Zhang QQ, Monia BP, Marcusson EG, Dean NM. Inhibition of Bcl-xI expression sensitizes normal human keratinocytes and epithelial cells to apoptotic stimuli. Oncogene 1999;18:4495-4505.

34. Leiter U, Schmid RM, Kaskel P. Peter RU, Kraehn G. Antiapoptotic bcl-2 and bcl-xl in advanced malignant melanoma. Arch. Dermatol. Res. 2000;292:225232.

35. Tilli CM, Ramaekers FC, Broers JL, Hutchison CJ, Neumann HA. Lamin expression in normal human skin, actinic keratosis, squamous cell carcinoma and basal cell carcinoma. Br J Dermatol 2003:148(1):102-109. 



\title{
Chapter 4:
}

\author{
Nuclear lamins in the skin
}

\section{Lamin Expression in Normal Human Skin, Actinic Keratosis, Squamous Cell Carcinoma and Basal Cell Carcinoma}

\author{
CMLJ Tilli ${ }^{\dagger}{ }^{\dagger}$, FCS Ramaekers ${ }^{\dagger}$, JLV Broers ${ }^{\dagger}$, CJ Hutchison ${ }^{0}$, HAM Neumann ${ }^{\Uparrow}$ \\ Research Institute Growth \& Development (GROW), University of Maastricht, The \\ Netherlands \\ * Dept. of Dermatology, University Hospital Maastricht, The Netherlands \\ † Dept. of Molecular Cell Biology. University of Maastricht, The Netherlands \\ 0 Dept. of Biological Sciences, University of Dundee, United Kingdom \\ II Dept. of Dermatology \& Venereology, Erasmus University Rotterdam, Rotterdam, The \\ Netherlands
}

Published in British Journal of Dermatology (2003): 148:pp 102-109 


\begin{abstract}
Background

Aberrant expression patterns of nuclear lamins have been described in various types of cancer depending on the subtype of cancer, its aggressiveness, proliferative capacity and degree of differentiation. In general, the expression of A-type lamins (lamins A and C) has been correlated with a non-proliferating, differentiated state of cells and tissues.
\end{abstract}

\title{
Objectives
}

To establish and compare the expression patterns of lamins in normal human skin, actinic keratosis (AK), squamous cell carcinoma (SCC) and basal cell carcinoma (BCC).

\section{Methods}

Expression patterns of the individual lamin subtypes were studied immunohistochemically. The proliferation capacity of the tumor cells was detected using a specific antibody to $\mathrm{Ki}-67$, and was related to the A-type lamin expression patterns.

\section{Results}

In normal skin, lamin A was expressed in the suprabasal cell compartment of the epidermis, whereas the basal cells were mostly unstained. BCCs and SCCs stained positive in the most cells, while the epidermis overlying BCC and SCC and the epidermis in AK stained homogeneously and strongly in the basal cells in addition to the suprabasal cells. Lamin C was expressed in some basal cells of normal epidermis, while the suprabasal cells stained strongly positive. Both BCCs and SCCs stained strongly positive for lamin C, with the difference that in $\mathrm{BCC}$ the staining was predominantly present in nucleolar structures with occasional staining of the nuclear envelope. The epidermis overlying SCC showed strong positivity in the lamina of virtually all cells. The expression of lamin C in the basal cells of AK resembled the expression pattern seen in the epidermis overlying BCC, i.e. a nucleolar staining next to nuclear envelope staining. Lamin B1 and B2 were found in virtually all cells in normal epidermis, AK, BCCs, SCCs and the epidermis overlying cancer. The percentage of Ki- 67 expressing cells was highest in BCC $(45 \%)$, and gradually decreased via epidermis overlying BCC, AK, SCC, epidermis overlying SCC to normal skin $(11 \%)$. Simultaneous expression of A-type lamins and Ki-67 occurred in approximately $50 \%$ of the proliferating (Ki-67 positive) cells in BCC and SCC.

\section{Conclusion}

Significant changes occur in the expression patterns of A-type lamins in both pre-malignant and malignant lesions of the skin. The profound overlap of lamin $\mathrm{A}$ and $\mathrm{Ki}-67$ staining patterns indicates that the proliferating tumor cells may obtain a certain degree of differentiation. Finally, lamin A expression in the basal cell layer of the apparently normal epidermis overlying BCC may suggest its involvement in the primary process.

Keywords: actinic keratosis, basal cell carcinoma, epidermis, lamins, proliferation, squamous cell carcinoma 


\section{Introduction}

Nuclear lamins are intermediate filament proteins that form a network at the nucleoplasmic site of the nuclear membrane. Two subtypes of nuclear lamins exist in humans, i.e. A-type lamins (also designated Statins), including lamin A, lamin $A \Delta 10$ and lamin $C$, all three arising from the same gene by alternative splicing $^{1.2}$, and B-type lamins, i.e. lamin B1 and lamin B2, arising from two distinct genes $^{3,4}$. In general, the A-type lamins are expressed in differentiated cells and tissues, whereas B-type lamins are also expressed in undifferentiated cells. From previous studies it became clear that the expression of both A-type lamins and B-type lamins is differentially regulated in human tissues ${ }^{5}$ and during embryogenesis ${ }^{6}$.

Lamins share many characteristics with the other intermediate filament subclasses, but they are located exclusively in the nucleoplasm instead of the cytoplasm. A nuclear localization signal at the carboxy- terminus directs the transport into the nucleus ${ }^{7}$. Furthermore, the nuclear lamins form twodimensional sheets underlying the nuclear membrane, while cytoplasmatic intermediate filaments form fibrous structures extending from nucleus to plasma membrane ${ }^{8}$.

Although many biochemical and molecular features have been studied, the function of the lamins remains largely undetermined. It can be assumed that nuclear lamins not only maintain the integrity of the nucleus and the position of nuclear pore complexes, but are also thought to be important in maintaining the interphase organization of chromatin ${ }^{9}$ and may be involved in the regulation of gene expression ${ }^{10,11}$. Spann et $a l^{12}$ showed that alteration of lamin organization inhibits transcription and thereby regulates gene activity.

Aberrant expression patterns of lamins have been described in cancer. The nuclear matrix may play a role in cancer development as a result of alterations in protein expression during transformation ${ }^{13}$. Earlier studies have shown that lamin expression in some tumors is dependent on the subtype of cancer, its aggressiveness, proliferative capacity and degree of differentiation ${ }^{14-16}$. In general, A-type lamin expression is correlated with a non-proliferating, differentiated state of cells and tissues ${ }^{6}$, and therefore one would expect an altered expression of A-type lamins in cancer. In basal cell carcinoma (BCC), Venables et al. ${ }^{17}$ have recently demonstrated that the absence of lamin $A$ correlated with rapid growth, while the absence of lamin C correlated with slow growth of this skin tumor.

Furthermore, proteolytic lamin degradation has been shown in apoptotic cells ${ }^{18}$ and this degradation seems to proceed DNA fragmentation ${ }^{19}$. The presence of artificially introduced degradation-resistant lamins delays the process of apoptosis $^{20}$, suggesting that the nuclear lamins play an important part in the process of apoptosis by facilitating nuclear events during apoptosis, such as chromatin condensation. Since differences exist in the fraction of apoptotic cells in squamous cell carcinoma (SCC) and $\mathrm{BCC}^{21-24}$, a comparison was made of lamin staining patterns in these malignancies.

Thus, this study aims at establishing and comparing the expression patterns of lamins in normal human skin, actinic keratosis (AK), SCC and in BCC in order to investigate the role of lamins in the process of skin carcinogenesis. 


\section{Materials and methods}

\section{Tissues}

Samples of normal human skin $(n=5)$ were obtained from reduction surgery of human breast or abdomen. The BCC samples $(n=15)$ were obtained from Mohs' micrographic surgery. The AK $(n=5)$ and SCC $(n=10)$ specimens were obtained from biopsies. All specimens were snap-frozen in isopentane and $5 \mu \mathrm{m}$ sections were cut onto 3-aminopropyltrietoxysilan (APTS; Sigma-Aldrich Chemie BV, Zwijndrecht, The Netherlands) -coated slides, air-dried and fixed in acetone (10 minutes, $-20^{\circ} \mathrm{C}$ ).

Table 1: Antibodies and their dilutions used in this study

\begin{tabular}{|c|c|c|c|c|}
\hline Clone/Name & isotype & Antigen & Dilution & Reference/Source \\
\hline $41 \mathrm{CC} 4$ & mouse IgM & Lamins A/C & ud & Burke et al., $1983^{36}$ \\
\hline R27 & mouse IgM & Lamins AVC & ud & Zatloukal et al., $1992^{37}$ \\
\hline $133 \mathrm{~A} 2$ & mouse $\lg _{3}$ & Lamin A & $1 / 500$ & Abcam Ltd.,Cambridge, UK ${ }^{30}$ \\
\hline RaLC & rabbit polyclonal & Lamin C & $1 / 50$ & Abcam Ltd.,Cambridge, UK ${ }^{17}$ \\
\hline 119D5F1 & mouse $\lg _{1}$ & Lamin B1 & $1 / 250$ & Abcam Ltd.,Cambridge, UK ${ }^{26}$ \\
\hline LN43 & mouse IgG, & Lamin B2 & ud & Abcam Ltd.,Cambridge, UK ${ }^{36}$ \\
\hline$\times 223$ & mouse IgG, & Lamin B2 & ud & Research Diagnostics, NJ,USA ${ }^{3}$ \\
\hline A0047 & rabbit polyclonal & $\mathrm{Ki}-67$ & $1 / 200$ & DAKO A/S, Glostrup, DK \\
\hline
\end{tabular}

Abbreviation: $u d=$ undiluted

\section{Immunohistochemistry}

Table 1 shows the antibodies that were used in both immunoperoxidase and immunofluorescence staining procedures.

\section{-Immunoperoxidase staining protocol:}

All incubations were carried out at room temperature in a moist chamber. After incubation with the primary antibody for 1 hour, the slides were rinsed with phosphate buffered saline (PBS) ( $3 \times 5$ minutes). Then, a secondary antibody (either goat-anti-mouse IgG (SBA, Birmingham, AL, USA) or swine-anti-rabbit IgG (DAKO A/S; Glostrup, DK), dependent on the primary antibody) conjugated with peroxidase, was used to incubate the slides for 1 hour (1:100 diluted in PBS). After rinsing with PBS the slides were then incubated with 3,3'diaminobenzidine (DAB; Sigma-Aldrich Chemie BV), 1:10 diluted in PBS + $0,03 \% \mathrm{H}_{2} \mathrm{O}_{2}$, for 15 minutes. The slides were then rinsed with water for 15 minutes. Counterstaining was carried out with haematoxylin (Sigma-Aldrich Chemie BV). After dehydration the slides were embedded with Entellan (MERCK, Darmstadt, Germany). 
-Immunofluorescence staining protocol:

After overnight incubation at $4^{\circ} \mathrm{C}$ with the primary antibody, the slides were rinsed with PBS ( $3 \times 5$ minutes). Then, a secondary antibody (dependent on the primary antibody either goat-anti-mouse IgG or goat-anti-rabbit IgG), conjugated with a fluorescent label, was used to incubate the slides for 1 hour (1:100 diluted in PBS) at room temperature. After rinsing with PBS the slides were then embedded with TRIS-glycerol ( $\mathrm{pH} 8.0$ ) containing $0.5 \mu \mathrm{g} \mathrm{mL}^{-1}$ 4', 6-diamidin-2phenylindol-dihydrochloride (DAPI; Sigma-Aldrich Chemie BV).

Lamin A and Lamin C could be detected simultaneously using a mix of $133 \mathrm{~A} 2$ (mouse monoclonal antibody) and RaLC (affinity purified rabbit antiserum) for the incubation. The mix of secondary antibodies consisted of fluorescein isothiocyanate (FITC)-labeled goat-anti-mouse (DAKO A/S) and a Texas Redlabeled goat-anti-rabbit antibody (SBA). Lamin A and Ki-67 were detected simultaneously using a mix of $133 \mathrm{~A} 2$ and the rabbit polyclonal serum A0047.

Table 2: Major lamin expression patterns in normal skin, actinic keratosis (AK), squamous cell carcinoma (SCC) and basal cell carcinoma (BCC)

\section{Tissue} Lamin A Lamin C Lamin B1 Lamin B2

Normal skin $(n=5)$

basal layer

suprabasal layers

AK $(n=5)$

basal layer

suprabasal layers

$++\quad+$ (nucleoli/lamina)

$+\quad+$ (nucleoli)

$+\quad++$

$+1-$

$\operatorname{SCC}(n=10)$

Epidermis overlying SCC

basal layer

suprabasal layers

$\operatorname{BCC}(n=15)$

$++\quad+$ (nucleoli)

Epidermis overlying $\mathrm{BCC}$

basal layer

$++\quad+$ (nucleoli/lamina)

suprabasal layer

+ (nucleoli/lamina)

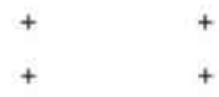

- no staining, +/-staining in small fraction of the cells , + positive staining in most cells,

++ positive staining in all cells 


\section{Results}

Table 2 shows the major lamin expression patterns in normal skin, AK, SCC and $\mathrm{BCC}$.

\section{Lamin expression in normal skin and actinic keratosis}

Lamin A was found predominantly in the suprabasal cell layers of the normal epidermis (Fig. 1A), while lamin C was occasionally present also in the basal cell (Fig. 1B). Stromal cells stained positive for both lamins A and C. In AK, lamin A was expressed in all cells of the basal layer as well as in most cells of suprabasal layers in all cases (Fig. 1C). Lamin C was found in the most basal and suprabasal cell layers in all cases, showing a predominant nucleolar localization (Fig. 1D).

B-type lamins were found to be expressed throughout the entire epidermis (Fig. $2 A, B)$, which was similar to the pattern seen in AK. Stromal cells only seldomly stained positive for lamin B1, whereas lamin B2 was present in these cells.

\section{Lamin expression in squamous cell carcinoma}

Lamin A was detected in all or most cells in the basal and suprabasal cell layers of the apparently normal epidermis overlying SCC, whereas lamin C was expressed in all or most basal cells and in all cells in the suprabasal cell layers of the apparently epidermis overlying SCC (Fig. 3A,B). The B-type lamins showed slightly reduced expression levels in the basal cell layer of the epidermis overlying SCC as compared to normal skin.

Lamin A was detected in all or most tumor cells, with lamin C being expressed in most tumor cells of all cases, both showing a nuclear lamina staining (Fig. $3 C, D)$. B-type lamins were found in most tumor cells.

\section{Lamin expression in basal cell carcinoma}

In the apparently normal epidermis overlying BCC, lamin A (Fig. 4A) could be detected in all or most cells in the basal cell layer. Only one case showed expression in a small fraction of the basal cell layer. Most cells in the suprabasal layers stained positive. For lamin C (Fig. 4B), most cases stained positive in all or most basal cells while four cases showed staining in a small fraction of the basal cells. Most or a small fraction of cells stained positive in the suprabasal layers. The staining was predominantly present at the nucleoli. Lamin B1 showed positivity in all or most cells in the basal cell layer, while a small fraction of cells in the suprabasal layers stained positive. Lamin B2 was detected in all or most cells in the basal and suprabasal cell layers.

In BCC, lamin A stained positive in all or most tumor cells, showing a nuclear envelope localization (Fig. $4 \mathrm{C}$ ). Lamin $\mathrm{C}$ stained positive in all or most tumor cells. Only one case expressed lamin $C$ in a small fraction of tumor cells. The staining was predominantly localized in the nucleoli (Fig. 4D), while in two cases the nuclear envelope was also stained. Lamin B1 expression was detected in all or most tumor cells, only one case showing staining in a small fraction of tumor cells. Lamin B2 stained positive in most tumor cells. 


\section{$\mathrm{Ki}-67 /$ lamin A co-expression}

$\mathrm{Ki}-67$ positivity in normal human epidermis was mainly restricted to the suprabasal cell layers of the epidermis; these cells were either scattered throughout this layer, or clustered in certain areas, with an average of $11 \%$ positive cells (Fig. 5A).

In BCC, Ki-67 stained positive in the tumor cells at the periphery of most of the nodules in the nodular type, and in a somewhat more variable pattern in the morpheaform type. However, areas with a high number of cells expressing $\mathrm{Ki}$ 67 occurred adjacent to areas with a lower number of Ki-67 positive cells. The average of $\mathrm{Ki}-67$ expressing tumor cells in BCC was $45 \%$. The epidermis overlying BCC also showed increased numbers of cells positive for Ki-67 (35\%) as compared to the epidermis in normal human skin with suprabasal layers of the epidermis also showing positive cells (Fig. 5B). In SCC, Ki-67 expression was predominantly located at the periphery of the nodules with an average of $20 \%$ of tumor cells being positive. The epidermis overlying SCC showed an average of $18 \%$ of cells expressing $\mathrm{Ki}-67$. AK showed an average of $31 \%$ of $\mathrm{Ki}-$ 67 expressing cells in the epidermis.

Co-expression of lamin A and $\mathrm{Ki}-67$ occurred in $62 \%$ of the proliferating (Ki-67 positive) tumor cells in BCC (Fig. $5 \mathrm{C}$ ) and in $56 \%$ of the tumor cells in SCC.

\section{Discussion}

Previous studies have shown that the nuclear lamina participates in interphase chromatin organization, DNA replication and gene expression ${ }^{9-12}$. Its integrity seems instrumental in the regulation of apoptosis ${ }^{20}$. Therefore, it is possible that changes in the lamina can affect the balance between cell proliferation and apoptosis in various cell types. In this study we investigated the differential expression patterns of the nuclear lamins in normal human skin, AK and in nonmelanoma skin cancers SCC and BCC.

The lamin A expression in the basal cell layer of the epidermis overlying BCC, SCC and AK, in contrast with its exclusively suprabasal localization in normal skin, may suggest an involvement of these basal cells in the carcinogenic process. Also, it cannot be excluded that factors originating from the tumors may induce this differentiated-like phenotype of the basal cells. Furthermore, based on this abnormal expression pattern, antibodies against lamin A may be used to differentiate between normal human skin and diseased skin. With respect to lamin A expression in BCC, a striking difference was observed when comparing our results with these of Venables et al. ${ }^{17}$. Although similar distribution patterns were obtained in normal human skin, and a partially overlapping panel of antibodies was applied, we found a higher frequency of lamin A expressing cells in BCC. 


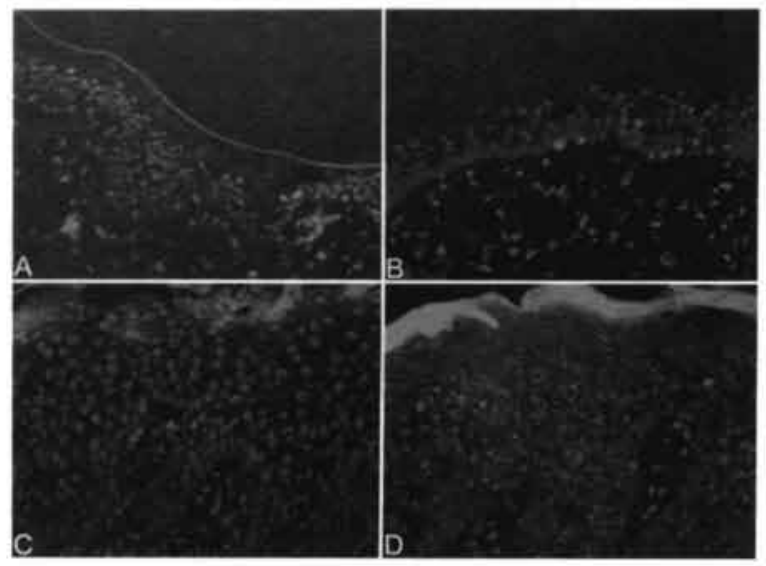

basal, as well as in the suprabasal cell layers.
Figure 1: A-type lamins in normal human skin and actinic keratosis

A. Lamin A (133A2); predominantly found in the suprabasal cell layers of the epidermis of normal human skin.

B. Lamin C (RaLC); occasionally present in basal cells next to a more homogeneous expression in the suprabasal layers of the epidermis of normal human skin.

C. Lamin A (133A2); expressed in the basal cell layer as well ass in the majority of the cells in the suprabasal cell layers in actinic keratosis.

D. Lamin C (RaLC) showing a nucleolar staining pattern in the

Original magnification used for photography of images A-D was 20x.

Figure 2: B-type lamins in normal human skin. Lamin B1 (119D5F1, A) and Lamin B2 (LN43, B) are both expressed throughout the entire epidermis of normal human skin.

Original magnification used for photography of images A and B was 20x.
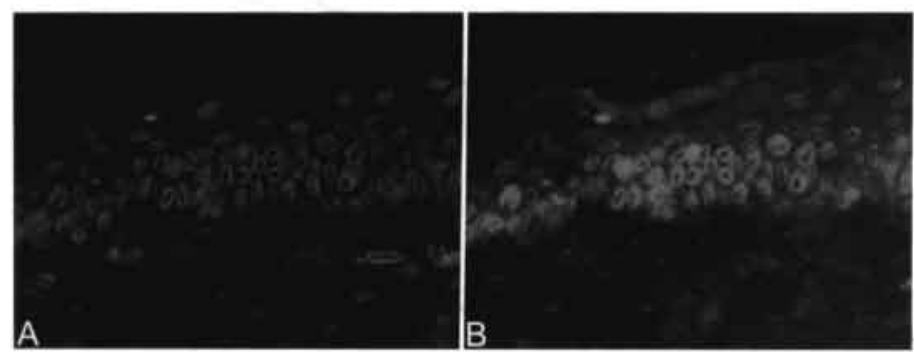
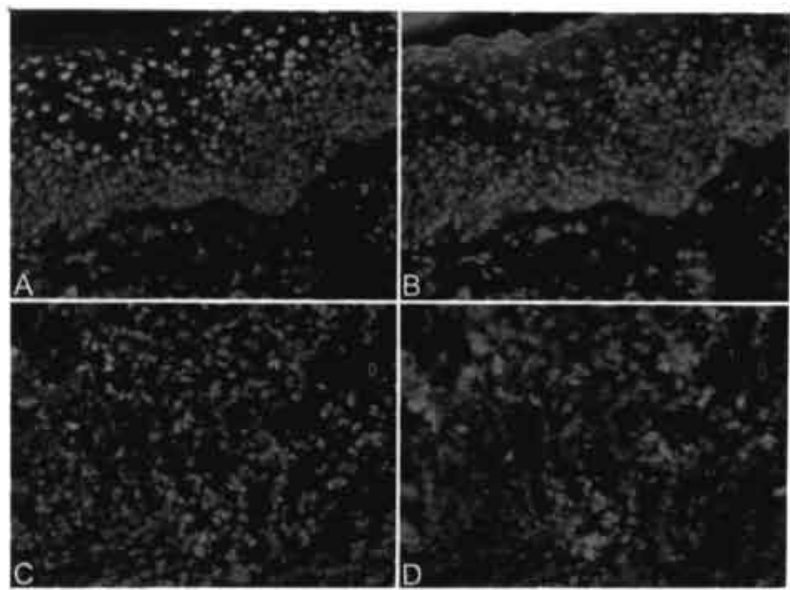

Figure 3: Lamin expression in squamous cell carcinoma and in the epidermis overlying squamous cell carcinoma

A: Lamin A (133A2) showing a homogeneous staining of the basal cells of the epidermis overlying squamous cell carcinoma, the majority of the suprabasal cells also staining positive.

B: Lamin C (RaLC); also expressed in the majority of cells of the epidermis overlying squamous cell carcinoma, with a localization at the nuclear envelope.
C: Lamin
A
(133A2);

homogeneously expressed at the nuclear lamina in the tumor cells.

D: Lamin C (RaLC); expressed in the majority of tumor cells and also showing a localization at the nuclear envelope.

Original magnification used for photography of images A-D was $20 \mathrm{x}$. 

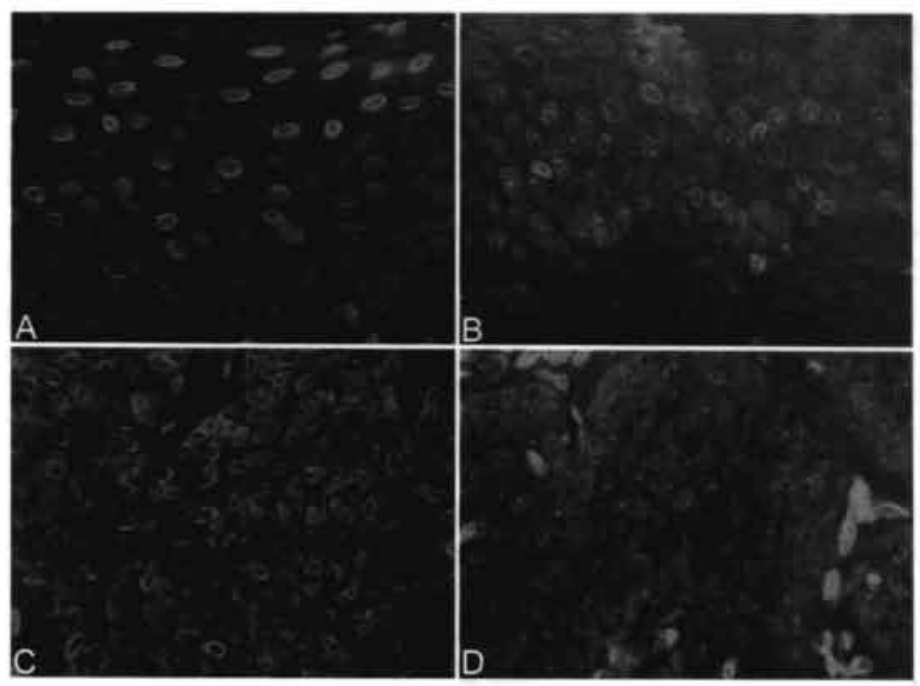

nuclear envelope next to localization at the nucleoli.

C: Lamin A (133A2); homogeneously expressed in the tumor cells.

D: Lamin C (RaLC); expressed in the majority of tumor cells but showing a localization at the nucleoli.

Original magnification used for photography of images A-D was 40x.
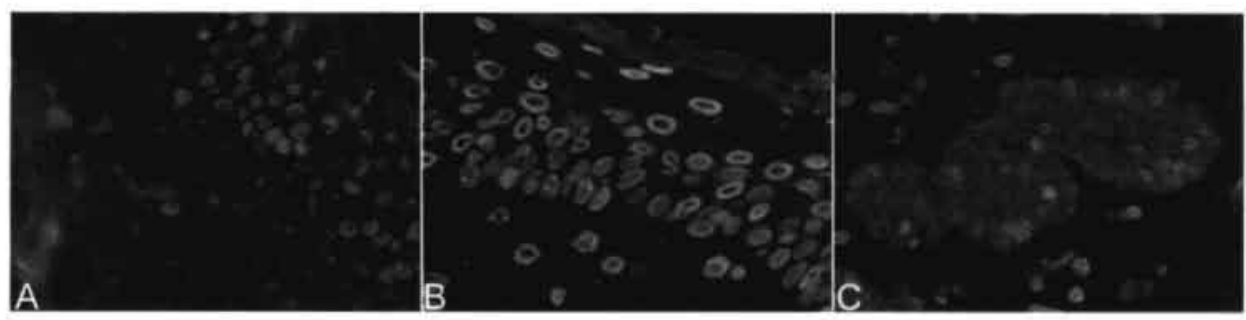

Figure 5: Ki-67/lamin A co-expression in normal human skin and basal cell carcinoma (BCC) A: Lamin A (green) and $\mathrm{Ki}-67$ (red) in normal human skin: Ki-67 positivity is mainly restricted to the suprabasal cell layers as is the expression of lamin A.

B: Lamin A (green) and Ki-67 (red) in the epidermis overlying basal cell carcinoma: Ki-67 positivity is enhanced as compared to that in normal human epidermis. Lamin A is homogeneously expressed in the basal cell layer of the epidermis overlying basal cell carcinoma in contrast to its absence in basal cells of normal human skin.

C: Co-expression of lamin A (green) and $\mathrm{Ki}-67$ (red) in basal cell carcinoma.

Original magnification used for photography of images $A$ and $B$ was $40 x$, for image $C 20 x$. 
The mechanism by which the aberrant localization of lamin C in AK and BCC occurs is still unclear. Nuclear foci of lamin expression have been reported before in the case of A-type lamins ${ }^{25,26}$. The authors suggested that these clustered A-type lamins form deposits from which the lamins will finally be transported to and assembled in the peripheral nuclear lamina. Aberrant expression of A-type lamins has furthermore been reported in non-small cell lung carcinoma ${ }^{16}$. Cytoplasmic localization of lamin A was observed and partially explained by the possibility that the lamins were improperly assembled or even truncated. Deletion of either the lamin A N-terminal domain or the Cterminal $\mathrm{CaaX}$ domain results in the formation of intra-nuclear aggregates and disruption of the endogenous lamins $\mathrm{A}$ and $\mathrm{C}^{27}$. Vaughan et al. ${ }^{28}$ showed that absence of lamin A from the nuclear envelope correlated with a significant fraction of lamin $\mathrm{C}$ being mis-localized to the nucleolus. Although it thus seemed likely that lamin $A$ is essential for the localization of lamin $C$ to the nuclear envelope, the present study shows that the mis-localization of lamin $\mathrm{C}$ to the nucleolus appears to be independent of lamin A. Jagatheesan et al. ${ }^{29}$ found a speckled pattern of expression for A-type lamins in HeLa cells. These speckles were found to co-localize with RNA splicing factors and the speckles dispersed when the cells entered mitosis. The speckled pattern of expression was also seen by Hozak et $a l^{30}$, who stated that internal lamins are normally buried in dense chromatin and are thus inaccessible for antibodies. After removal of the chromatin, the internal 'speckly' labeling increases for both lamin A and lamin A/C antibodies. However, no effect was seen on the labeling of lamin B2, which remained predominantly located at the peripheral lamina. Furthermore, lamin foci were found to be associated with sites of DNA replication ${ }^{31}$. In addition, mislocalization of lamin $\mathrm{C}$ to the nucleolus might be a first step towards its absence in higher-grade tumors as is suggested in the studies of Venables et al. ${ }^{17}$. It is at least remarkable that the nucleolar localization is restricted to $\mathrm{AK}$ and $\mathrm{BCC}$, and not seen in SCC and normal epidermis.

Regarding simultaneous expression of lamin A an KI-67, our findings corroborate with previous studies stating that AK possesses more proliferative capacity than $\mathrm{SCC}^{32-35}$. The differences in proliferation may partially explain their differential clinical behavior.

In normal tissue A-type lamins are in general restricted to differentiated, nonproliferative, cells ${ }^{5}$. In the skin tumors examined, however, we found coexpression of lamin A and Ki-67 can in approximately $60 \%$ of the proliferating cells. This simultaneous expression was also observed by Janssen et al. ${ }^{14}$ who showed that a considerable fraction of the Ki-67 positive Reed-Sternberg and Hodgkin cells expressed also A-type lamins, indicating that those proliferating cells had a differentiated phenotype. Our recent results in BCC are contrasted by the findings of Venables et al. ${ }^{17}$, who reported mutually exclusive staining patterns for lamin $\mathrm{A}$ and $\mathrm{Ki}-67$. The major methodological differences between the two studies were that Venables et al. ${ }^{17}$ used single staining of serial sections and therefore were unable to demonstrate conclusively that lamin A was absent from Ki67 positive cells. Furthermore, there seemed to be an apparent correlation between the absence of lamin $\mathrm{C}$ and a low proliferative index in their series of BCC. This conclusion was also based on staining of serial sections with the individual antibodies. We feel that the double-staining 
protocol used in the present study may allow a more accurate comparison of the distribution patterns of Ki-67 and lamin A. We therefore conclude that the double-stained malignant cells are of a differentiated phenotype but still possess proliferative capacity.

A sequence of change in lamin expression may characterize basal cell skin carcinoma. Based upon the findings reported here and those reported previously ${ }^{17}$, four stages in the development of $\mathrm{BCC}$ might be revealed by different patterns on A-type lamin expression. Venables et al. ${ }^{17}$ reported a high incidence of lamin A negative, Ki-67 positive tumors (stage 1) and suggested that this group was representative of the origins of the tumor since basal cells tend to be lamin A negative and $\mathrm{Ki}-67$ positive in normal skin. In this study a significant group of BCCs were lamin A positive and Ki-67 positive (stage 2). Up-regulation of lamin A expression in this instance might accompany tumor dedifferentiation. In these tumors a fraction of lamin C was located in the nucleolus. In Venables studies ${ }^{17}$, lamin $\mathrm{C}$ was found in the nucleolus in one tumor (stage 3 ) and was completely absent (stage 4 ) in a number of others. All of these tumors had a low proliferative index. Since BCC is characterized by slow growth and an absence of metastasis, this might represent a final phase in the differentiation process. Thus we propose that tumor progression in BCC is characterized by absence of lamin A at its origin (stage 1), but as the tumor progresses lamin A expression is up-regulated (stage 2). During these two phases tumor cells divide rapidly. As growth slows down, lamin C is first relocated to the nucleolus (stage 3 ) and subsequently its expression is largely diminished (stage 4). Whether these changes in lamin expression influence or reflect changes in the growth of the tumor is yet to be investigated. 


\section{References}

1 Lin F. Worman HJ. Structural organisation of the human gene encoding nuclear lamin A and nuclear lamin C. J. Biol. Chem. 1993; 268: 16321-6.

2 Machiels BM, Zorenc AHG, Endert JM et al. An alternative splicing product of the lamin A/C gene lacks exon 10. J. Biol. Chem. 1996; 271: 9249-53.

3 Hoeger TH, Zatloukal $\mathrm{K}$, Waizenegger I et al. Characterization of a second highly conserved B-type lamin present in cells previously thought to contain only a single B-type lamin. Chromosoma 1990; 99: 379-90.

Lin F. Worman HJ. Structural organisation of the human gene (LMNB1) encoding nuclear lamin B1. Genomics 1995; 27: 230-6.

5 Broers JLV, Machiels BM, Kuijpers $\mathrm{HJH}$ et al. A- and B-type lamins are differentially expressed in normal human tissues. Histochem. Cell Biol. 1997; 107: 505-17.

Roeber RA, Weber $\mathrm{K}$, Osborn M. Differential timing of nuclear lamin A/C expression in the various organs of the mouse embryo and the young animal: a developmental study. Development 1989; 105: 365-78.

Loewinger L, McKeon F. Mutations in the nuclear lamin proteins resulting in their aberrant assembly in the cytoplasm. EMBO J. 1988; 7:2301-9.

Monteiro MJ. Hicks C, Gu L et al. Determinants for intracellular sorting of cytoplasmic and nuclear intermediate filaments. J. Cell Biol. 1994; 127: 132743.

Nagle RB. A review of intermediate filament biology and their use in pathologic diagnosis. Mol. Biol. Rep. 1994; 19: 3-21.

10 Furukawa K, Hotta Y. cDNA cloning of a germ cell specific lamin B3 from mouse spermatocytes and analysis of its function by ectopic expression in somatic cells. EMBO J. 1993; 12: 97-106.

11 Moir RD, Spann TP, Goldman RD. The dynamic properties and possible functions of nuclear lamins. Int. Rev. Cytol. 1995; 162B: 141-82.

12 Spann TP, Goldman AE, Wang C et al. Alteration of nuclear lamin organisation inhibits RNA polymerase II- dependent transcription. J Cell Biol 2002; 156: 6038.

13 Replogle-Schwab R, Pienta KJ, Getzenberg RH. The utilisation of nuclear matrix proteins for cancer diagnosis. Crit. Rev. Euk. Gene Exp. 1996; 6: 103-13.

14 Jansen MPHM, Machiels BM, Hopman AHN et al. Comparison of A- and Btype lamin expression in nodular sclerosing Hodgkin's disease and reactive lymph nodes. Histopathology 1997; 31: 304-12.

15 Machiels BM, Ramaekers FCS, Kuijpers HJH et al. Nuclear lamin expression in normal testis and testicular germ cell tumors of adolescents and adults. $J$. Pathol. 1997; 182: 197-204.

16 Broers JLV, Raymond Y, Klein Rot $\mathrm{M}$ et al. Nuclear A-type lamins are differentially expressed in human lung cancer subtypes. Am. J. Pathol. 1993; 143: 211-20.

17 Venables RS, McLean S, Luny D et al. Expression of individual lamins in basal cell carcinomas of the skin. Br. J. Cancer 2001; 84: 512-9.

18 Oberhammer FA, Hochegger K, Froeschl G et al. Chromatin condensation during apoptosis is accompanied by degradation of lamin $A+B$, without enhanced activation of cdc2 kinase. J. Cell Biol. 1994; 126: 827-37.

19 Neamati N, Fernandez A, Wright S et al. Degradation of lamin B1 precedes oligonucleosomal DNA fragmentation in apoptotic thymocytes and isolated thymocyte nuclei. J. Immunol. 1995; 154: 3788-95.

20 Rao L, Perez D, White E. Lamin proteolysis facilitates nuclear events during apoptosis. J. Cell Biol. 1996; 135: 1441-55. 
21 Tilli CMLJ, Stavast-Kooy AJW, Ramaekers FCS et al. Bax expression and growth behavior of basal cell carcinomas. J. Cutan. Pathol. 2002; 29: 79-87.

22 Verhaegh MEJM, Sanders CJG, Arends JW et al. Expression of the apoptosissuppressing protein bcl-2 in non-melanoma skin cancer. Br. J. Dermatol. 1995; 132: $740-4$.

23 Rodriguez-Villanueva J, Colome MI, Brisbay S et al. The expression and localisation of bcl-2 protein in normal skin and in non-melanoma skin cancers. Path. Res. Pract. 1995; 191: 391-8.

24 Morales-Ducret JCR, Van de Rijn M, LeBrun DP et al. Bcl-2 expression in primary malignancies of the skin. Arch. Dermatol. 1995; 131: 909-12.

25 Sasseville M-J, Raymond Y. Lamin A precursor is localised to intranuclear foci. J. Cell Sci. 1995; 108: 273-85.

26 Machiels BM, Broers JLV, Raymond $\mathrm{R}$ et al. Abnormal A-type lamin organisation in a human lung carcinoma cell line. Eur. J. Cell Biol. 1995; 67: 328-35.

27 Izumi M, Vaughan OA, Hutchison CJ et al. Head and/or CaaX deletions of lamin proteins disrupt preformed lamin A and C but not lamin B structure in mammalian cells. Mol. Biol. Cell 2000; 11: 4323-37.

28 Vaughan OA, Alvarez-Reyes M, Bridger JM et al. Both emerin and lamin C depend on lamin A for localisation at the nuclear envelope. J. Cell Sci. 2001; 114: $2577-90$.

29 Jagatheesan G, Thanumalayan S, Muralikrishna B et al. Colocalisation of intranuclear lamin foci with RNA splicing factors. J. Cell Sci. 1999; 112: 465161.

30 Hozak P, Sasseville AM-J, Raymond $Y$ et al. Lamin proteins form an internal nucleoskeleton as well as a peripheral lamina in human cells. J. Cell Sci. 1995; 108: $635-44$.

31 Moir RD, Spann TD, Goldman RD. The dynamic properties of nuclear lamins: lamin B is associated with sites of DNA replication. J. Cell Biol. 1994; 125: 1201-12.

32 Wrone-Smith T, Bergstrom J, Quevedo ME et al. Differential expression of cell survival and cell cycle regulatory proteins in cutaneous squamoproliferative lesions. J. Dermatol. Sci. 1999; 19: 53-67.

33 Smith K, Williams J, Corbett D et al. Microcystic adnexal carcinoma: an immunohistochemical study including markers of proliferation and apoptosis. Am. J. Surg. Pathol. 2001; 25: 464-71.

34 Horlock NM, Wilson GD, Daley FM et al. Cellular proliferation characteristics of basal cell carcinoma: relationship to clinical subtype and histopathology. Eur. J. Surg. Oncol 1997; 23: 247-52.

35 Shimizu T, Muto M, Murakami T et al. Overexpression of p53 protein associated with proliferative activity as evaluated by $\mathrm{Ki}-67$ immunostaining in welldifferentiated squamous cell carcinoma of the skin. Dermatology 1997; 195: 224-7.

36 Burke B, Tooze G, Warren G. A monoclonal antibody which recognises each of the nuclear lamin polypeptides in mammalian cells. EMBO J. 1983; 2: 361-7.

37 Zatloukal K, Denk H, Spurej G et al. Modulation of protein composition of nuclear lamina- reduction of lamins-B1 and lamins-B2 in livers of griseofulvintreated mice. Lab. Invest. 1992; 66: 589-97.

38 Bridger JM, Kill IR, O'Farrel M et al. Internal lamin structures within G1 nuclei of human dermal fibroblasts. J. Cell Sci. 1993; 104: 297-306. 



\section{Chapter 5: Therapy of BCC}

\section{The garlic derived organosulfur component ajoene decreases basal cell carcinoma tumor size by inducing apoptosis}

CMLJ Tilli ${ }^{1}$, AJW Stavast-Kooy ${ }^{1}$, JDD Vuerstaek ${ }^{1}$, MRTM Thissen ${ }^{1}$, GAM Krekels $^{1}$, FCS Ramaekers ${ }^{2}$, HAM Neumann ${ }^{3}$

Research Institute Growth \& Development (GROW) University of Maastricht, The Netherlands

1 Dept. of Dermatology, University Hospital Maastricht, The Netherlands

2 Dept. of Molecular Cell Biology, University of Maastricht, The Netherlands

3 Dept. of Dermatology \& Venereology, Erasmus University Rotterdam, The Netherlands

Published in Archives of Dermatological Research (2003):295:pp117-123 


\section{Abstract}

Although the therapeutical role of ajoene, an organosulfur compound of garlic, in cardiovascular diseases and mycology has been established, its usefulness in cancer treatment has only recently been suggested. We have applied ajoene topically to 21 patients with either nodular or superficial basal cell carcinoma (BCC), resulting in a reduction of tumor size in seventeen patients. Immunohistochemical assays for $\mathrm{Bcl}-2$ expression in a selection of these tumors before and after treatment showed a significant decrease of this apoptosis-suppressing protein. On average, the percentage of tumor cells expressing the proliferation marker $\mathrm{Ki}-67$ was not decreased, which contradicts a cytostatic action of ajoene. To obtain further insight into the mode of action of ajoene, BCC cell line TE354T and short-term primary culture of BCC were analyzed for apoptosis induction after treatment with the drug. Apoptosis was detected by morphology of the cells and by flow cytometry. It could be demonstrated that ajoene induces apoptosis in a dose and time dependent manner in these cultures.

Taking together the in vivo and in vitro studies, we conclude that ajoene can reduce $\mathrm{BCC}$ tumor size, mainly by inducing the mitochondrion-dependent route of apoptosis.

Keywords: ajoene, apoptosis, basal cell carcinoma, Bcl-2, cell cycle 


\section{Introduction}

Basal cell carcinoma (BCC), a non-melanoma type of skin cancer, is the most common malignancy in Caucasians. Although generally of indolent nature, occasionally the tumor can become very aggressive and destructive'. For treatment of BCC several surgical and non-surgical therapies are available ${ }^{2}$. Standard therapies include primary surgical excision, Mohs' micrographic surgery and cryosurgery. Surgical therapy is preferred in the case of uncomplicated $\mathrm{BCCs}^{3}$. The medical history of the patient, age, tumor localization and size, physical condition and histological outcome will eventually determine the therapy choice. Non-surgical treatment schedules become increasingly important because of better cosmetic result. Non-invasive therapies like photodynamic therapy (PDT) that uses 5-aminolevulinic acid (5-ALA) as a photosensitizer ${ }^{4.5}$ are still under investigation. Topical application 5-fluorouracil has also been proven successful in the treatment of $\mathrm{BCC}^{6}$.

One of the approaches by which BCC can be treated is by the induction of apoptosis in the tumor cells. Our earlier studies do however indicate that a major fraction of BCC is largely positive for the anti-apoptotic $\mathrm{Bcl}-2^{7.8}$, thus suggesting a protection of the tumor cells against programmed cell death. Drugs that can induce this process in BCC may therefore become important tools in non-surgical therapy of this widespread disease.

More and more phytochemicals are being applied in cancer prevention and therapy ${ }^{9}$. Several epidemiological studies have revealed that garlic consumption has played a significant role in the reduction of deaths caused by malignant diseases. The mortality rate among patients with gastric cancer in China was significantly lower in patients with higher garlic consumption (about $20 \mathrm{~g} /$ day) than in patients with lower garlic consumption ${ }^{10}$. Similar effects were seen in gastric cancer patients in Italy $^{11}$. Since then, a number of studies have appeared on the anti-tumor and cytotoxic actions of garlic and its organosulfur compounds.

Ajoene, an organosulfur compound of garlic, possesses anti-fungal activity ${ }^{12}$, inhibits platelet aggregation ${ }^{13}$, and has been shown to induce apoptosis in human promyeloleukemic cells ${ }^{14}$. Furthermore, these authors showed that ajoene can inhibit the expression of inducible nitric oxide synthase (iNOS), a major enzyme in the production of nitric oxide (NO) in activated macrophages ${ }^{15}$. During inflammatory processes cytokines induce the expression of iNOS in endothelial cells, followed by high output NO synthesis ${ }^{16.17}$. This NO is thought to serve as nonspecific immuneprotector ${ }^{18}$ and can mediate the onset of apoptosis in a variety of mammalian cells ${ }^{19}$. Suschek et al. ${ }^{20}$ reported that NO prevents UV-induced apoptosis in the skin and that this NO-mediated protection tightly correlates with over-expression of the apoptosis-inhibiting component $\mathrm{Bcl}-2$. Therefore, we studied the expression patterns of the $\mathrm{Bcl}-2$ protein before and after ajoene treatment of BCC to determine its apoptosis inducing effect.

Since several authors ${ }^{21,22}$ suggested an effect of ajoene on cell cycle progression, we furthermore investigated the effect of ajoene on proliferative activity of the tumor cells by determining Ki-67 expression. 


\title{
Materials and Methods
}

\begin{abstract}
Ajoene
Ajoene [(E)-4,5,9-trithiododeca-1,6,11-triene-9-oxide $]$ was purified from alcoholic extracts of garlic as described before 23. Briefly, allicin (a diallyl thiosulfinate that is produced when garlic is crushed) produces ajoene by incubation of a $2 \%$ solution of allicin in acetone/water $(3 / 2)$ at $80^{\circ} \mathrm{C}$ for $10 \mathrm{~h}$. The crude product is then purified by column chromatography.
\end{abstract}

\section{Ajoene treatment in vivo}

Twenty-one patients (12 males and 9 females, in age ranging from $49-91$ years) with twenty-five individual histologically proven BCC of nodular $(n=17)$ or superficial $(n=8)$ type with a maximum diameter of $2 \mathrm{~cm}$ were selected. Patients with a suppressed immune system or using immune-suppressive drugs were excluded. All patients signed an informed consent prior to their inclusion in the study, which was approved by an Institutional Review Board (Ethics Committee). Before treatment, the surface area $\left(\mathrm{mm}^{2}\right)$ of the lesions was determined and a biopsy ( $3 \mathrm{~mm}$ diameter) of the tumor was taken, fixed in $4 \%$ formaldehyde and embedded in paraffin. The BCCs were then treated by local application twice a day of a $0.4 \%$ ajoene cream $(400 \mathrm{mg}$ Ajoene, $0.3 \mathrm{ml}$ polysorbate 80 , and $0.3 \mathrm{ml}$ sorbitonoliate in $100 \mathrm{ml} 1 \%$ carbomeric gel) extending $1 \mathrm{~cm}$ beyond the tumor margins. The BCCs were then covered with a hydrocolloid dressing. The lesions were measured once a month. After treatment for 6 months, the BCCs were completely removed by surgical excision, fixed in $4 \%$ formaldehyde and embedded in paraffin.

\section{Immunohistochemistry of tissue sections}

Paraffin sections $(5 \mu \mathrm{m})$ were cut onto Superfrost plus slides (MERCK, Darmstadt, Germany), dried overnight at $56^{\circ} \mathrm{C}$, deparaffinized and rehydrated. Endogenous peroxidase activity was blocked with $0.3 \% \mathrm{H}_{2} \mathrm{O}_{2}$ /methanol and a microwave antigen-retrieval step was performed. The sections were then incubated with the primary antibodies Bcl-2 (Santa Cruz Biotechnology, Santa Cruz, CA, USA) or MIB-1 (Immunotech, Marseille, France) both diluted 1:50 in PBS, followed by incubation with the appropriate secondary antibodies, and detection via peroxidase with the ABC complex (Vector Laboratories Inc., Burlingame, CA, USA). Peroxidase activity was detected using 3,3diaminobenzidin (DAB; Sigma-Aldrich Chemie BV, Zwijndrecht, The Netherlands) as chromogen and the sections were counterstained using haematoxylin (Fluka AG, Buchs, Germany). After dehydration, the sections were then embedded using Entellan (MERCK).

The percentage of tumor cells expressing $\mathrm{Ki}-67$ and $\mathrm{Bcl}-2$ was established by counting a minimum of 500 cells per slide.

\section{BCC cell cultures}

The human BCC cell line TE354T (ATCC, Rochville, MD, USA) was cultured in DMEM (ICN Biomedicals, Cleveland, OH, USA) containing $10 \%$ FCS, $1 \%$ Lglutamine and $0,1 \%$ gentamycin. 
For primary cultures, BCC tumor tissue was obtained after informed consent, from patients undergoing Mohs' micrographic surgery, cut into small pieces and rinsed in calcium- and magnesium-free PBS. Then the tumor pieces were incubated overnight in DMEM containing $0,125 \%$ trypsin and $1 \%$ gentamycin at $37^{\circ} \mathrm{C}$. After incubation, the trypsinization was blocked by adding an equivalent amount of fetal calf serum (FCS) and by centrifugation of the solution for 5 minutes at $1200 \mathrm{rpm}$. The pellet was resuspended in serum-free keratinocyte medium (GIBCO, Paisley, Scotland, UK) and the washing step was repeated several times. Then the cells were inoculated in a small flask and put back at $37^{\circ} \mathrm{C}$. Medium was refreshed every other day. Fibroblasts were removed at sub-confluency by adding a solution of $0.125 \%$ trypsin and $0.02 \%$ EDTA in PBS for 30-60 seconds at room temperature. Loosened fibroblasts could then be decanted and the remaining cells were washed several times with medium. Normal keratinocytes are removed by increasing the calcium concentration from $0.09 \mathrm{mM}$ to $1.6 \mathrm{mM}$ for a period of 5-7 days, after which the normal keratinocytes should be differentiated and non-proliferative. The remaining BCC colonies can than be returned to low calcium concentration medium.

\section{Immunohistochemistry of cell cultures}

The cell lines were characterized by immunohistochemical detection of several cytokeratins (CK). CK5 and CK14, detected by mouse monoclonal antibodies RCK $102^{24}$ and RCK $107^{25,26}$, respectively, are the basal cell keratins in combined and stratified epithelial tissues. CK8, CK18 and CK19 are present in glandular epithelial structures and carcinomas originating from them, and are detected by mouse monoclonal antibodies $\mathrm{M}_{2}{ }^{27}{ }_{2} \mathrm{RCK}_{106^{28}}$ and RCK108 ${ }^{29}$ respectively. Briefly, the cells were fixed on microscopy cover slides, rinsed in PBS and incubated overnight with the primary antibody at $4^{\circ} \mathrm{C}$. After rinsing with PBS, the cells were than incubated with the appropriate fluorescent-labeled secondary antibody at room temperature for 1 hour. After another washing step with PBS, the slides are mounted in TRIS-glycerol $(\mathrm{pH} \mathrm{8.0)}$ containing 0.5 $\mu \mathrm{g} / \mathrm{mL} \quad 4$,,$\quad 6$-diamidin-2-phenylindol-dihydrochloride (DAPI; Sigma-Aldrich Chemie BV).

\section{Ajoene treatment of cell cultures}

Ajoene was dissolved in dimethylsulfoxide (DMSO; MERCK) and further diluted in the appropriate medium. Ajoene was added to the cells for increasing time periods (6-24 hours) and in three different concentrations i.e. $1 \mathrm{mM}, 5 \mathrm{mM}$ and $10 \mathrm{mM}$. Final DMSO concentration was less than $0.1 \%$ and has been shown not to interfere with the test results in control studies.

\section{Apoptosis assay}

The number of apoptotic cells was quantified using the annexin- $V$ assay ${ }^{30}$. After incubation with ajoene the cells are rinsed several times in PBS and once in $1 \mathrm{ml}$ annexin-binding buffer. The pellet was then resuspended in a solution containing annexin-V-FITC (1:500) (Nexins Research BV, Hoeven, The Netherlands) and propidium iodide (PI). Multi-parameter flow cytometry analysis was used to asses ajoene-induced apoptosis. In early stages of apoptosis, phosphatidylserine is exposed at the external surface of the cell and can be 
detected by annexin-V. Late apoptotic cells and necrotic cells will also show PI positivity. Living cells, however will show neither annexin-V, nor PI positivity.

\section{Flow cytometry}

Flow cytometric analyses were performed using the FACSort flow cytometer (Becton Dickinson, Heidelberg, Germany) equipped with a single Argon ion laser. Fluorochromes were excited at $488 \mathrm{~nm}$, and the emission filters used were 515-545 BP (green, FITC) and 600 LP (red, PI). A minimum of $10^{4}$ cells per sample was analyzed and data stored in list mode. FITC signals were recorded as logarithmic amplified data, while the PI signals (DNA content per cell) were recorded as linear amplified data. For bi-variate FITC/PI analysis no compensation was used. Forward and side scatter of cells was recovered to observe morphological changes of cells. All analyses were performed with Cell Quest software (Becton Dickinson).

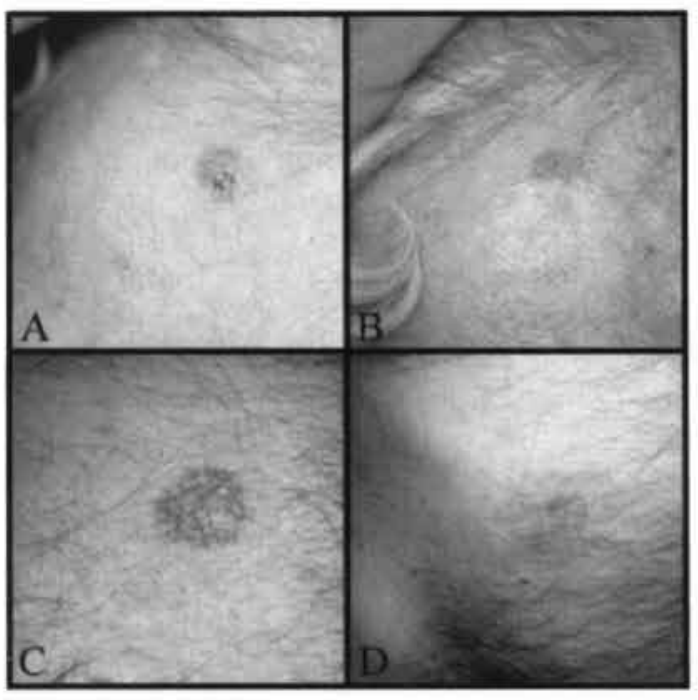

Figure 1: Effect of ajoene on BCC tumor size after topical application in patients.

$B C C$ located on the forehead $(A, B)$ and on the abdomen $(C, D)$, before $(A, C)$ and after $(B, D)$ topical treatment with ajoene. Tumor surface areas are as follows A: $63 \mathrm{~mm}^{2}, B: 42 \mathrm{~mm}^{2}, \mathrm{C}$ : $195 \mathrm{~mm}^{2}$, D: $24 \mathrm{~mm}^{2}$.

\section{Results}

To study the effect of ajoene on BCC, 21 patients with in total 25 lesions were treated by exogenous application of the organosulfur compound. The in vivo results were verified and extended by in vitro studies on human BCC cell lines.

\section{Effect of ajoene on tumor size, $\mathrm{Bcl}-2$ and $\mathrm{Ki}-67$ expression}

Although the patient studies showed heterogeneous results, and immunohistochemistry indicates that only a subset of the cells is targeted, the abundance of BCCs showed a positive response to ajoene with respect to size reduction and decrease of $\mathrm{Bcl}-2$ expression. 
Figure 1 shows the effect of ajoene containing cream on the surface area of BCCs of two patients after treatment during 6 months. Of the cases examined, 3 tumors showed an increase in tumor size, in 1 tumor no change in size was noted while in 21 samples tumor size was reduced (Fig. 2). On average, the size of the BCCs in this study showed a reduction with a median value of $47 \%$ (ranging from $69 \%$ increase to $88 \%$ decrease) ( $p<0.01$; Wilcoxon), of which $42 \%$ (ranging from $69 \%$ increase to $82 \%$ decrease) for the nodular type (case numbers $1,4-7,9-15,17,19,21,23$ and 24 ) and $55 \%$ (ranging from $19 \%$ increase to $88 \%$ decrease) for the superficial type of BCC (case numbers 2,3 , $8,16,18,20,22$ and 25$)$.

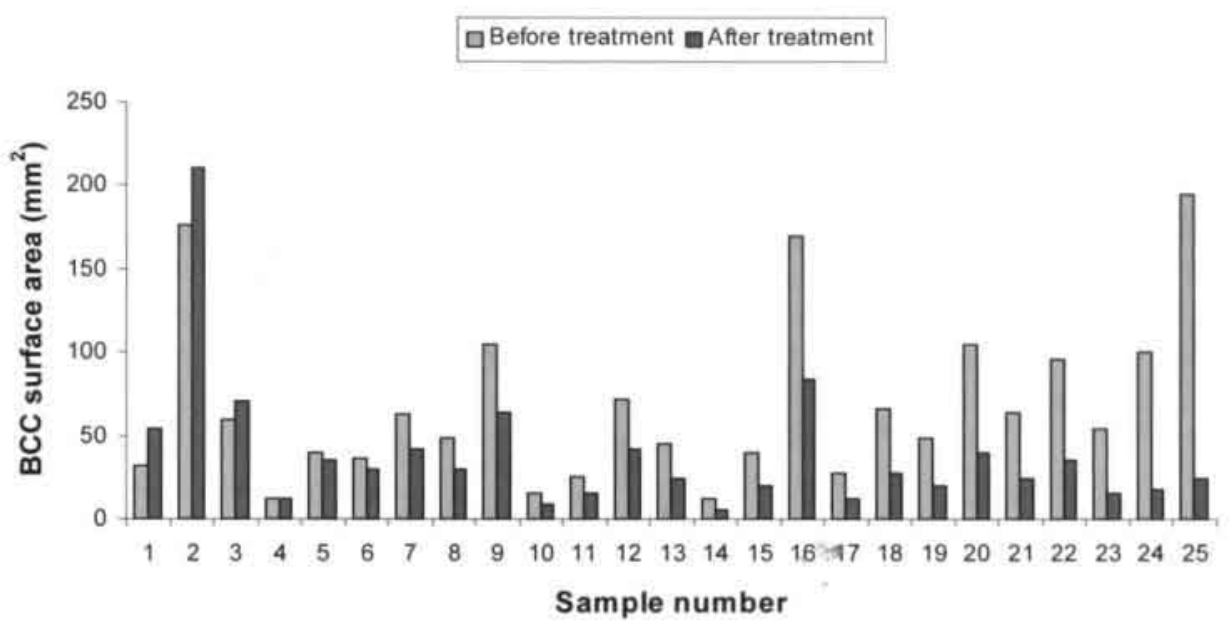

Figure 2: Effect of ajoene on tumor size after topical application in the individual samples.

Samples were aligned as follows: 1-3 Tumors of increased size after treatment; 4 Tumor without change in size; 5-25 Tumors of decreased size after treatment.

Figure $3 \mathrm{~A}$ shows a selection of 10 cases covering tumors that show either growth, standstill or regression under influence of ajoene. Figure 3B shows the percentage of $\mathrm{Bcl}-2$ expressing tumor cells per tumor before and after treatment with ajoene in this selection. It is obvious that in all cases but one the number of cells expressing $\mathrm{Bcl}-2$ decreased dramatically i.e. a median reduction value of $47 \%$ (ranging from $4 \%$ increase to $72 \%$ decrease) ( $p<0.01$; Wilcoxon). For the nodular type BCC (sample numbers $1,4,5,12,17$ and 21) this approximated $39 \%$ (ranging from $4 \%$ increase to $72 \%$ decrease) and for the superficial type BCC (sample numbers 2, 3, 22 and 25 ) $50 \%$ (ranging from $33 \%$ decrease to $69 \%$ decrease).

Figure $3 \mathrm{C}$ shows the percentage of $\mathrm{Ki}-67$ expressing tumor cells per sample before and after treatment. It can be seen that in six cases a decrease in proliferation index is detected, while in four cases the number of Ki-67 positive cells was increased. When nodular and superficial type of BCC were analyzed separately, nodular BCC (sample numbers 1, 4, 5, 12, 17 and 21) showed a 
decrease with the median value of $2 \%$ (ranging from $167 \%$ increase to $25 \%$ decrease) of $\mathrm{Ki}-67$ positive cells, in contrast to a decrease for the superficial type of $21 \%$ (ranging from $10 \%$ increase to $72 \%$ decrease) (sample numbers 2 , 3,22 and 25). On average, no significant change was detected for the percentage of $\mathrm{Ki}-67$ expressing cells before and after ajoene treatment. In fact, four of the ten $(40 \%)$ samples examined show an increase of the number of $\mathrm{Ki}$ 67 positive cells after ajoene treatment. This indicates that the effect of ajoene on cell proliferation is not consistent in BCC.

口Before ajoene treatment $\mathrm{E}$ After ajoene treatment
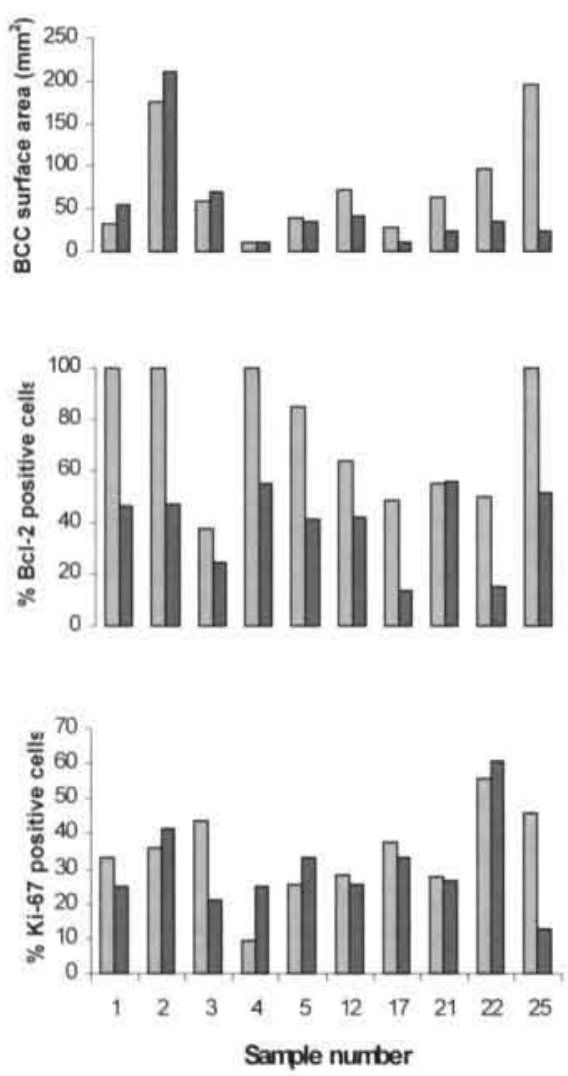

Figure 3: Correlation of the effect of ajoene on tumor size, Bcl-2 and $\mathrm{Ki}-67$ expression in a selection of BCC.

Samples were selected based on their divergent response to ajoene, i.e. 1-3 Tumors of increased size after treatment; 4 Tumor without change in size; remaining cases show tumors of decreased size after treatment. A: BCC surface area $\left(\mathrm{mm}^{2}\right)$ before and after ajoene treatment.

$\mathrm{B}$ : Percentages of $\mathrm{Bcl}-2$ expression in $\mathrm{BCC}$ tumor cells before and after ajoene treatment.

C: Percentages of Ki-67 expression in $\mathrm{BCC}$ tumor cells before and after ajoene treatment. 


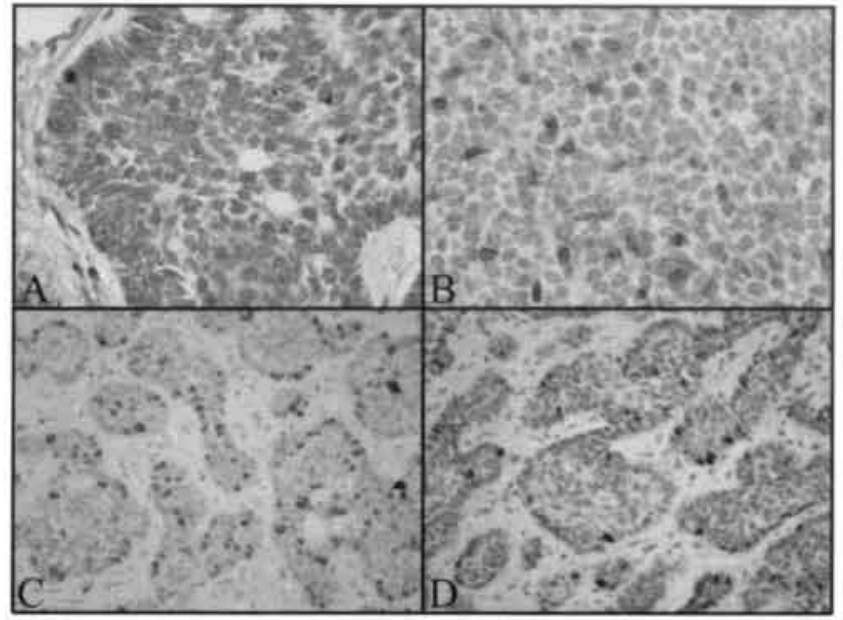

Figure 4: $\mathrm{Bcl}-2(\mathrm{~A}, \mathrm{~B})$ and $\mathrm{Ki}-67(C, D)$ staining in $B C C$ before $(A, C)$ and after $(B, D)$ ajoene treatment.

Original magnifications for images A-B: 40x, for images C-D: $20 \mathrm{x}$

Figure 4 shows examples of immunohistochemical staining patterns for $\mathrm{Bcl}-2$ (Fig. 4A, B) and Ki-67 (Fig. 4C, D) in BCC, either before (A,C) or after (B,D) treatment for 6 months with ajoene. Bcl-2 showed a homogeneous staining pattern before ajoene treatment in contrast to a clearly reduced expression pattern after topical application of ajoene. For Ki-67, no significant changes in the number of expressing cells could be detected.

\section{CK expression profile of BCC cell lines}

Cells of both TE354T and the short-term BCC cell culture showed strong positive immunoreactivity to the antibodies directed against CK 5 and 14 in the majority of the cells (results not shown), whereas no reactivity could be detected for CK18. Positivity for CK8 and CK19 was found in a small fraction of the cells. This CK-profile is compatible with a BCC origin of the cell cultures 31,32 .

\section{Effect of ajoene on apoptosis in BCC cell cultures}

To further investigate the underlying mechanism of the (potentially) growth inhibitory effect of ajoene in vivo, we used BCC cell cultures for more advanced apoptosis assays. The results of the annexin- $V$ assay are depicted in Figure 5. It can clearly be seen that the apoptosis induction in BCC cell culture, either commercially available or derived from short-term cell culture, is both dose- and time-dependent. It can be noted that BCC cells from short-term culture are more susceptible for apoptosis induction by Ajoene than the commercially available BCC cell line, a phenomenon that may be related to a higher growth rate noted for the short-term culture. Furthermore, $10 \mathrm{mM}$ Ajoene seems to have an almost optimal effect on apoptosis induction, especially after 24 hours. 
A

6hrs D

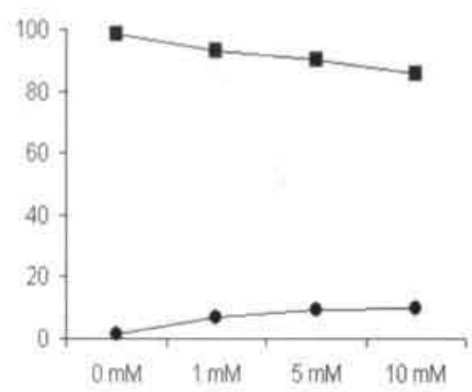

B

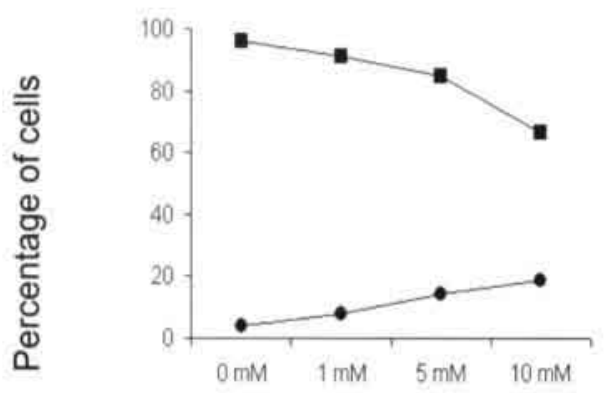

C

24hrs

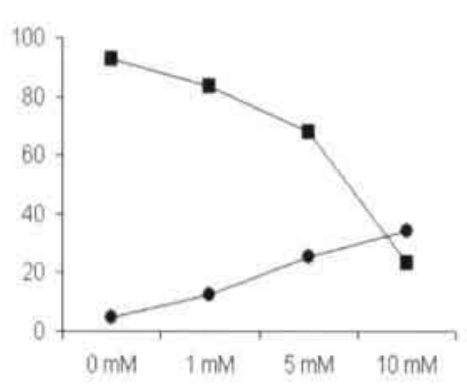

Concentration Ajoene

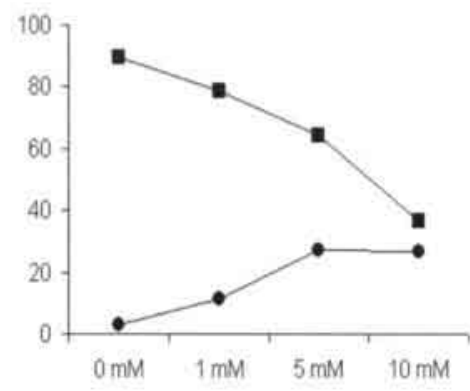

E

$12 \mathrm{hrs}$
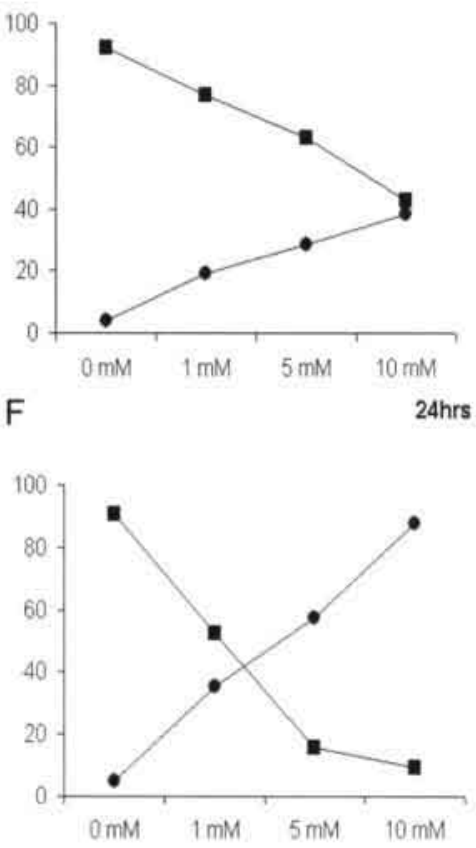

Concentration Ajoene

Figure 5: The effect of incubation with ajoene on cell viability in TE354T cell line (A-C) and short-term culture of basal cell carcinoma (D-F). The fraction of living cells is depicted as squares, the fraction of apoptotic cells is depicted as dots. 


\section{Discussion}

Several therapies for the treatment of BCC exist ${ }^{2}$. In general, surgical excision is the therapy of first choice, but it may be obvious that a non-invasive treatment is preferred. Here we show for the first time that ajoene, a sulfur-containing compound of garlic, is effective in the treatment of BCC. The present study also aimed at elucidating the underlying biological effect of this phytochemical. We showed that $84 \%$ of the tumors, treated with an ajoene-containing cream were significantly reduced in size after 6 months of treatment. It was shown that the superficial tumors showed a larger reduction in size next to a larger reduction in the number of cells expressing $\mathrm{Bcl}-2$, as compared to the nodular tumors, which may be explained by the fact that the ajoene cream can more easily penetrate the superficial tumors. A similar differential effect on tumor size reduction was previously seen in case of treatment of BCC with PDT. Complete initial clearance of more than $90 \%$ for superficial lesions was seen in contrast to 10 $64 \%$ for nodular $\mathrm{BCC}^{33,34}$. Another possible topical treatment for BCC is imiquimod. Imiquimod is an immune response modifier that has been demonstrated to induce cytokines such as interferon-alpha, interferon-gamma and interleukin 12 that promote an immune response in the tumor cells ${ }^{35,36}$. However, in the majority $(92 \%)$ of BCC patients treated with imiquimod, local reactions were seen at the tumor site including erythema, itching, crusting and even severe erosion ${ }^{37}$. This is in contrast to our study using ajoene where no significant side effects were observed.

When comparing the Ki-67 immunostaining results before and after topical application of ajoene to $\mathrm{BCC}$ in patients, no reproducible shift in the percentage of Ki-67 positive cells was noted. BCCs showing an increased proliferative cell fraction were seen next to tumors with a decreased proliferative activity. Therefore we can conclude that in BCC patients the anti-tumorigenic effect of ajoene is not only explained by a cytostatic effect of the drug.

Tumor size reduction may therefore be better explained by the apoptosisinducing ability of ajoene. To test this hypothesis we have applied an assay to directly prove a diminished protection against apoptosis, rather than procedures to detect apoptotic cells in BCC, such as the TUNEL assay ${ }^{38}$. The latter protocol normally also detects necrotic cells and is therefore non-specific, which can explain the divergent results in the literature, showing between $0.6 \%$ and $51 \%$ of apparently apoptotic cells in BCC ${ }^{39-41}$. The Annexin V-assay 30 or the M30 Cytodeath assay ${ }^{42}$ cannot be used in case of tissue sections of BCC. Furthermore, the real apoptotic fraction is rapidly cleared from the tumor by phagocytosis. Immunohistochemical staining of the tumors treated with ajoene revealed a decreased number of cells expressing Bcl-2. This provides a possible mechanism for the effect of ajoene on BCC. By reducing the number of Bcl-2 positive, apoptosis-resistant, tumor cells, ajoene may increase the susceptibility for apoptosis in the tumor cells, which will eventually result in a reduction of tumor size.

This finding is furthermore supported by the observation that, when added to the culture medium of BCC cells, ajoene induces apoptosis in these cells. This apoptosis-inducing effect is both time and dose dependent. Taken together, 
these findings provide an important step in dissolving the underlying molecular mechanisms of the anti-tumor action of ajoene.

Recently Dirsch et al. ${ }^{43}$ and Ahmed et al. ${ }^{44}$ proved that ajoene induces apoptosis in leukemic cell lines by triggering the mitochondria-dependent caspase cascade. The authors furthermore reported that Bcl-2 expression was significantly decreased in these cells ${ }^{44}$ and that over-expression of $\mathrm{Bcl}-\mathrm{x}(\mathrm{L})$, an apoptosis-regulating protein, clearly diminished the ajoene-induced caspaseactivation as well as apoptosis ${ }^{43}$. Kwon et al. ${ }^{45}$ reported that diallyl disulfide (DADS), another component of garlic, induces apoptosis of human leukemia $\mathrm{HL}-60$ cells in a concentration- and time-dependent manner.

We conclude that ajoene can have a diminishing effect on the growth of $\mathrm{BCC}$ by influencing the disturbed balance between proliferation and apoptosis. Our earlier studies showed that on average $6 \%$ of the tumor cells in BCC show both an increased proliferative activity as well as a reduced apoptotic susceptibility ${ }^{7}$. It is most likely that this progressive cell population is the most sensitive target for ajoene treatment.

\section{Acknowledgements}

The authors would like to thank Dr. Rafael Apitz- Castro from Instituto Venezuelano des Investigationes Scientifica in Caracas, Venezuela for the preparation of the ajoene, used in our experiments. Furthermore Prof. Dr. H.C. Hemker and Prof. Dr. S. Beguin are also thanked for their participation in this study. 


\section{References}

1

2

3

4

Jacobs GH, Rippey JJ, Altini M. Prediction of aggressive behavior in basal cell carcinoma. Cancer 1982; 49: 533-7.

Telfer NR, Colver GB, Bowers PW. Guidelines for the management of basal cell carcinomas. Br. J. Dermatol. 1999; 141: 415-23.

Rowe DE, Carroll RJ, Day CL. Long term recurrence rates in previously untreated (primary) basal cell carcinoma: implications for patient follow-up. $J$. Dermatol. Surg. 1989; 15: 315-28.

Thissen MRTM, Schroeter CA, Neumann HAM. Effective photodynamic therapy with 5 -aminolevulinic acid for nodular basal cell carcinomas using a preceding debulking technique. Br. J. Dermatol. 2000; 142: 338-9.

Kennedy JC, Pottier RH, Pross DC. Photodynamic therapy with endogenous protoporphyrin IX: basic principles and present clinical experience. J Photochem. Photobiol. 1990; 6: 143-8.

Miller BH, Shavin JS, Cognetta A et al. Nonsurgical treatment of basal cell carcinomas with intralesional 5-fluorouracil/epinephrine injectable gel. $J$ Am Acad Dermatol 1997; 36: 72-7.

Tilli CMLJ, Stavast-Kooy AJW, Ramaekers FCS et al. Bax expression and growth behavior of basal cell carcinomas. J. Cutan. Pathol. 2002; 29: 79-87.

Verhaegh MEJM, Sanders CJG, Arends JW et al. Expression of the apoptosissuppressing protein bcl-2 in non-melanoma skin cancer. Br. J. Dermatol. 1995; 132: $740-4$.

Hoffman EJ. Cancer and the search for selective biochemical inhibitors. CRC Press LLC, Boca Raton, FI, USA 1999.

You WC, Blot WJ, Chang YS et al. Allium vegetables and reduced risk of stomach cancer. J Natl Cancer Inst 1989; 81: 162-4.

Buiatti $E$, Palli D, Decarli $A$ et al. A case-control study of gastric cancer and diet in Italy. Int J Cancer 1989; 44: 611-6.

Yoshida S, Kasuga S, Hayashi $\mathrm{N}$ et al. Antifungal activity of ajoene derived from garlic. Appl Environ Microbiol 1987; 53: 615-7.

Apitz-Castro R, Ledezma E, Escalante $\mathrm{J}$ et al. The molecular basis of the antiplatelet action of ajoene: direct interaction with the fibrinogen receptor. Biochem Biophys Res Commun 1986; 141: 145-50.

Dirsch VM, Gerbes AL, Vollmar AM. Ajoene, a compound of garlic, induces apoptosis in human promyeloleukemic cells, accompanied by generation of reactive oxygen species and activation of nuclear factor kappaB. Mol Pharmacol 1998; 53: 402-7.

Dirsch VM, Kiemer AK, Wagner $\mathrm{H}$ et al. Effect of allicin and ajoene, two compounds of garlic, on inducible nitric oxide synthase. Atherosclerosis 1998; 139: 333-9.

Lamas S, Michel T, Collins T et al. Effects of interferon-gamma on nitric oxide synthase activity and endothelin-1 production by vascular endothelial cells. $J$ Clin Invest 1992; 90: 879-87.

Kilbourn RG, Belloni P. Endothelial cell production of nitrogen oxides in response to interferon gamma in combination with tumor necrosis factor, interleukin-1, or endotoxin. J Natl Cancer Inst 1990; 82: 772-6.

Liew FY, Cox FE. Nonspecific defence mechanism: the role of nitric oxide. Immunol Today 1991; 12: A17-21.

Kroncke KD, Fehsel K, Kolb-Bachofen V. Nitric oxide: cytotoxicity versus cytoprotection--how, why, when, and where? Nitric Oxide 1997; 1: 107-20.

Suschek CV, Krischel V, Bruch-Gerharz D et al. Nitric oxide fully protects against UVA-induced apoptosis in tight correlation with $\mathrm{Bcl}-2$ up-regulation. $J$ Biol Chem 1999; 274: 6130-7. 
21 Li M, Ciu J-R, Ye $Y$ et al. Antitumor activity of Z-ajoene, a natural compound purified from garlic: antimitotic and microtubule-interaction properties. Carcinogenesis 2002; 23: 573-9.

22 Nishikawa T, Yamada N, Hattori A et al. Inhibtition of skin tumor promotion in mice. Biosci Biotechnol Biochem 2002; 66: 2221-3.

23 Block E, Ahmad S, Catalfamo JL et al. Antithrombotic organosulfur compounds from garlic: Structural, mechanistic and synthetic studies. J Am Chem Soc 1986; 108: 7045-55.

24 Broers JLV, Carney DN, Klein Rot M et al. Intermediate filament proteins in classic and variant types of small cell lung carcinoma cell lines: a biochemical and immunochemical analysis using a panel of monoclonal and polyclonal antibodies. J Cell Sci 1986; 83: 37-60.

25 Smedts F, Ramaekers F, Troyanovsky S et al. Basal-cell keratins in cervical reserve cells and a comparison to their expression in cervical intraepithelial neoplasia. Am J Pathol 1992; 140: 601-12.

26 Wetzels $\mathrm{RH}$, Kuijpers $\mathrm{HJH}$, Lane EB et al. Basal cell-specific and hyperproliferation-related keratins in human breast cancer. Am J Pathol 1991; 138: 751-63.

27 Ku NO, Gish R, Wright TL et al. Keratin 8 mutations in patients with cryptogenic liver disease. N. Engl. J. Med. 2001; 344: 1580-7.

28 Smedts F, Ramaekers FCS, Robben $\mathrm{H}$ et al. Changing patterns of keratin expression during progression of cervical intraepithelial neoplasia. Am J Pathol 1990; 136: 657-68.

29 Kwaspen FH, Smedts FM, Broos A et al. Reproducible and highly sensitive detection of the broad spectrum epithelial marker keratin 19 in routine cancer diagnosis. Histopathology 1997; 31: 503-16.

30 van Engeland M, Nieland LJW, Ramaekers FCS et al. Annexin V-affinity assay: a review on an apoptosis detection system based on phosphatidylserine exposure. Cytometry 1998; 31: 1-9.

31 Krekels GAM, Verhaegh MEJM, Wagenaar S et al. Keratins (K8 and K19) as potential markers of recurrent basal cell carcinoma. Eur J Dermatol 1997; 7: 158-60.

32 Kooy AJW, Tank B, Vuzevski VD et al. Expression of cytokeratin 8 and other low molecular weight cytokeratins in human basal cell carcinoma. Anticancer Res 1995; 15: 241-7.

33 Svanberg K, Andersson T, Killander D et al. Photodynamic therapy of nonmelanoma malignant tumors of the skin using topical delta-amino levulinic acid sensitization and laser irradiation. Br J Dermatol 1994; 130: 743-51.

34 Wolf $\mathrm{P}$, Rieger $\mathrm{E}$, Kerl H. Topical photodynamic therapy with endogenous porphyrins after application of 5-aminolevulinic acid: an alternative treatment modality for solar keratosis, superficial squamous cell carcinomas and basal cell carcinomas ? J Am Acad Dermatol 1993; 28: 17-21.

35 Testerman TL, Gerster JF, Imbertson LM et al. Cytokine induction by the immunomodulators imiquimod and S-27609. J Leukoc Biol 1995; 58: 365-72.

36 Slade HB. Cytokine induction and modifying the immune response to human papilloma virus with imiquimod. Eur J Dermatol 1998; 8: 13-6; discussion 20-2.

37 Beutner KR, Geisse JK, Helman D et al. Therapeutic response of basal cell carcinoma to the immune response modifier imiquimod $5 \%$ cream. J Am Acad Dermatol 1999; 41: 1002-7.

38 Gravieli Y, Sherman Y, Ben-Sasson SA. Identification of programmed cell death in-situ via specific labeling of nuclear DNA fragmentation. J Cell Biol 1992; 119: 493-501.

39 Mooney EE, Ruis Peris JM, O'Neill A et al. Apoptotic and mitotic indexes in malignant melanoma and basal cell carcinoma. J. Clin. Pathol. 1995; 48: 242-4. 
40 Staibano S, Lo Muzio L, Mezza E et al. Prognostic value of apoptotic index in cutaneous basal cell carcinomas of head and neck. Oral Oncology 1999; 35: 541-7.

41 Wikonkal NM, Berg RJW, van Haselen CW et al. Bcl-2 versus p53 protein expression and apoptotic rate in human nonmelanoma skin cancers. Arch. Dermatol 1997; 133: 599-602.

42 Leers MP, Kolgen W, Bjorklund V et al. Immunocytochemical detection and mapping of a cytokeratin 18 neo-epitope exposed during early apoptosis. $J$ Pathol 1999; 187: 567-72.

43 Dirsch VM, Antlsperger DS, Hentze $\mathrm{H}$ et al. Ajoene, an experimental antileukemic drug: mechanism of cell death. Leukemia 2002; 16: 74-83.

44 Ahmed N, Laverick L, Sammons J et al. Ajoene, a garlic-derived natural compound, enhances chemotherapy-induced apoptosis in human myeloid leukaemia CD34-positive resistant cells. Anticancer Res. 2001; 21: 3519-23.

45 Kwon KB, Yoo SJ, Ryu DG et al. Induction of apoptosis by diallyl disulfide through activation of caspase- 3 in human leukemia HL-60 cells. Biochem Pharmacol 2002; 63: 41-7. 



\section{Summary}

Basal Cell Carcinoma (BCC) is a non-melanoma type of skin cancer that accounts for almost $80 \%$ of all skin malignancies and is the most common malignancy among Caucasians. Since apoptosis and proliferation are two important processes to be considered when studying growth characteristics of tumor, this thesis mainly concentrates on the (dis)balance between these two phenomena in BCC.

In the first chapter the molecular cell biology of BCC is being reviewed. Clinical features and the risk factors are discussed. Next to the obvious environmental risk factors such as exposure to sunlight and toxic agents, there are a number of genetically determined factors. Several syndromes exist, like Xeroderma Pigmentosum and Nevoid Basal Cell Carcinoma Syndrome, that may lead to a higher susceptibility for the development of BCC. Also immuno-suppression seems to play a major part in predisposing for the development of skin cancer. A subject of major interest is the origin of the tumor. There are several arguments for an inter-follicular epidermal origin, but most evidence points towards an origin from the hair follicle, and more specifically, the stem cells of the follicle, located in the bulge area.

Therefore, in the second chapter the human hair follicle is studied immunohistochemically, using the stem cell marker cytokeratin 19 and the apoptosis-suppressing protein $\mathrm{Bcl}-2$, to detect the localization of the stem cells. It seems that indeed two areas exist that may provide these cells. When the BCCs are studied for the expression pattern of $\mathrm{Bcl}-2$ (chapter 3.1), we see that the tumors express this apoptosis-regulating protein homogeneously. Remarkably however, the apparently normal epidermis overlying BCC also shows an enhanced expression of $\mathrm{Bcl}-2$, in contrast with a strict basal cell localization in the healthy epidermis. This suggests that superficial tumors may arise from the basal cells, whereas the nodular and morphea type may originate from the hair follicles, and may explain why both epidermis and hair follicle show comparable patterns of expression for some proteins such as cytokeratins and cell adhesion molecules. This is also found in the study using other $\mathrm{Bcl}-2$ like proteins (chapter 3.2), where BCCs show a basal cell-like phenotype and the overlying epidermis again shows an intermediate expression pattern between normal epidermis and BCC. Whether this phenomenon is induced by factors originating from $B C C$ or can be regarded as a first step in skin carcinogenesis remains to be established.

In chapter 4 the differential expression patterns of nuclear lamins, which are related to differentiation and proliferation, are shown in different stages of skin cancer. Significant changes occur in the expression patterns of A-type lamins in both pre-malignant and malignant lesions of the skin. The profound overlap of staining patterns of lamin A and the proliferation marker Ki-67 indicates that the proliferating tumor cells may obtain a certain degree of differentiation. Also, lamin A expression in the basal cell layer of the apparently normal epidermis 
overlying BCC again suggests its involvement in the primary process. Furthermore, a sequence of four stages in the development of BCC is revealed by different patterns of A-type lamin expression. Stage 1 is represented by a high incidence of lamin A negative, Ki-67 positive tumors. As the tumor progresses to stage 2, lamin A expression is upregulated. During these two first stages the tumor shows a high degree of proliferation. When growth slows down in stage 3, lamin C expression is first relocated to the nucleoli and subsequently its expression is largely diminished during stage 4 , the stage at which the cells obtain their final BCC phenotype.

In chapter $\mathbf{5}$ a possible new treatment for BCC is introduced by applying ajoene, an organosulfur compound of garlic, directly to the tumors. The in vivo studies showed a clear diminishing effect on tumor size in most cases and suggested selective induction of apoptosis by down-regulating the expression of the anti-apoptotic $\mathrm{Bcl}-2$ protein. These findings were furthermore supported by in vitro studies, showing that ajoene can induce apoptosis in both a BCC cell line and a short-term primary culture of BCC. A major advantage of this treatment is that ajoene showed no side effects in normal skin. This study provides a good basis to further investigate apoptosis-inducing agents for their future application in BCC treatment. 


\section{Samenvatting}

Het basaalcelcarcinoom (BCC) is een niet-melanoma type huidkanker dat ongeveer $80 \%$ van alle maligne huidaandoeningen uitmaakt. Het is de meest voorkomende maligniteit in mensen van het Caucasische ras. Aangezien apoptose en proliferatie twee belangrijke processen zijn die in acht genomen moeten worden wanneer men groeikarakteristieken van een tumor onderzoekt, concentreert deze thesis zich met name op de (verstoorde) balans tussen deze twee fenomenen in BCC.

In Hoofdstuk 1 werd de moleculaire celbiologie van BCC besproken. Klinische kenmerken en risico-factoren worden besproken. Naast de overduidelijke omgevingsfactoren zoals blootsltelling aan zonlicht en gifstoffen, zijn er ook een aantal genetische factoren. $\mathrm{Er}$ bestaan verschillende syndromen, zoals bijvoorbeeld Xeroderma Pigmentosum en Nevoid Basaal Cel Carcinoma Syndroom, die aanleiding geven tot een hogere gevoeligheid voor de ontwikkeling van BCC. Daarnaast speelt immuunsuppressie ook een grote rol. Een onderwerp van grote belangstelling is het ontstaan van een BCC. Er zijn verschillende argumenten die duiden op een oorsprong in de interfolliculaire epidermis, echter de meeste bewijzen duiden op een oorsprong in de haarfollikels, en meer specifiek, de stamcellen van de follikel, gelocaliseerd in het zogenaamde 'bulge' gebied.

Daarom werd in Hoofdstuk 2 de menselijke haarfollikel onderworpen aan een immunohistochemische analyse, gebruik makend van de stamcel merker cytokeratine 19 en het apoptose-onderdrukkende $\mathrm{Bcl}-2$ eiwit, om de localisatie van de stamcellen te determineren. Er blijken inderdaad twee gebieden aanwezig te zijn die mogelijk stamcellen leveren. Wanneer BCCs immunohistochemisch bestudeerd worden voor de expressie van het $\mathrm{Bcl}-2$ eiwit (Hoofdstuk 3.1), zien we dat de tumoren dit apoptose-regulerend eiwit homogeen tot expressie brengen. Opmerkelijk is echter, dat de schijnbaar normale epidermis boven de tumor ook een verhoogde expressie van het Bcl-2 eiwit vertoont, in tegenstelling tot wat we zien een gezonde huid, waar het Bcl-2 eiwit enkel in de basal laag tot expressie komt. Deze bevindingen suggereren dat de superfaciele tumoren ontstaan van de interfolliculaire epidermis, en dat de nodulaire en sprieterige types ontstaan uit de haarfollikels, en verklaren tevens waarom zowel epidermis als haarfollikels vergelijkbare expressie patronen van eiwitten zoals de cytokeratines en cel-adhesie moleculen vertonen. Dit werd ook geconstateerd in een studie naar Bcl-2-gerelateerde eiwitten in BCC (Hoofdstuk 3.2), waar BCCs een fenotype vertonen gelijkaardig aan de basale cellen, en de overliggende epidermis opnieuw een expressie patroon vertoont dat tussen dat van gezonde huid en BCC ligt. De vraag of dit fenomeen wordt geinduceerd door factoren die afkomstig zijn van het BCC of dat dit gezien kan worden als een eerste stap in het ontstaan van huidkanker blijt voorlopig nog onbeantwoord. 
In Hoofdstuk 4 werden de differentiele expressie patronen van de nucleaire lamines, eiwitten gerelateerd aan proliferatie en differentiatie, besproken in de verschillende stadia van huidkanker. Significante veranderingen treden op in de expressie patronen van de A-type lamines in zowel pre-maligne als maligne huidaandoeningen. De overduidelijke simultane expressie van lamine $A$ en de proliferatie merker $\mathrm{Ki}-67$ duidt op het feit dat de prolifererende tumor cellen beschikken over een zekere graad van differentiatie. Verder duidt de aanwezigheid van lamine $A$ in de basale laag van de schijnbaar normale overliggende epidermis op een betrokkenheid van deze cellaag in het primaire proces. Op basis van de differentiele expressie patronen van lamin A kunnen er vier stadia onderscheiden worden in de ontwikkeling van een BCC. Het eerste stadium wordt gekenmerkt door de aanwezigheid van lamine A negatieve, Ki-67 positieve tumoren. Progressie naar stadium 2 gaat gepaard met op-regulatie van de expressie van lamine A. Gedurende deze twee eerste stadia vertonen de tumoren een hoge proliferatie index. Wanneer de proliferatie afneemt in het derde stadium, wordt lamine $\mathrm{C}$ herlocaliseerd naar de nucleoli alvorens gedurende stadium 4 te verdwijnen; dit is het stadium waar de cellen hun uitendelijke BCC fenotype aannemen.

In Hoofdstuk 5 werd een mogelijke nieuwe behandeling voor BCC geintroduceert, door een directe applicatie van ajoene, een bestanddeel van knoflook. De in vivo studies vertonen een duidelijke reductie in tumor afmeting in het merendeel van de bestudeerde patienten en sugereren een selectieve inductie van apoptosis door vermindering van de expressie van het apotoseonderdrukkende eiwit $\mathrm{BCl}-2$. De resultaten werden bevestigd door in vitro studies waaruit is gebleken dat ajoene apoptose kan induceren in zowel een korte-termijn kweek van BCC als een commercieel verkrijgbare BCC cellijn. Een groot voordeel van deze behandeling is dat ajoene geen bijwerkingen vertoont in de normale huid. De studie levert een geode basis voor de verder studie naar apoptose-inducerende reagentie en hun toekomstige toepassing in behandeling van $\mathrm{BCC}$. 


\section{Dankwoord}

'Hoe moet ik hier nu aan beginnen?', dat vroeg ik me af toen ik aan mijn dankwoord wilde beginnen. Het dankwoord, de tekst die als laatst geschreven wordt, maar waarschijnlijk als eerst gelezen. Bij de ontvangst van proefschriften zie je altijd iedereen direct doorbladeren naar de laatste bladzijden, om te kijken wie er al dan niet vermeld wordt in het dankwoord. Ik moet toegeven, dat deed ik ook altijd. Als tweede waren dan de stellingen aan de beurt. Eigenlijk is dat toch wel schandalig, de stukken die het minst met het onderzoek te maken hebben worden als eerste grondig bestudeerd en door sommigen hevig bekritiseerd. Wat weten zij daar nu van? Velen van hun weten niet welke zware taken het zijn om deze tekstjes te produceren. Waarschijnlijk beseffen ze niet dat hier meer bloed, zweet, tranen en slapeloze nachten aan vooraf zijn gegaan dan voor de rest van het 'boekje'. De (soms) prachtig geïllustreerde verhalen die het grootste deel van het boek uitmaken, zijn immers op voorhand al uitbundig besproken met de nodige co-auteurs en de AIO wordt als het ware aan het handje geleid naar het einde. Maar dan, het dankwoord, de grote test voor iedere schrijver, nu komt het enkel en alleen op de AIO zelf aan. En 'wee je gebeente' als je iemand vergeten bent.

$\mathrm{Ja}$ ja, ik ben het aan het uitstellen, ik probeer er een beetje omheen te schrijven om het penibele moment maar uit te stellen. Ik heb nachten lang gedacht over een originele manier om mijn dankwoord neer te schrijven, maar de ideeën die ik kreeg waren slechts zwakke kopieën van de andere 'originelen'. Ik heb er zelfs over gedacht om het dankwoord gewoon helemaal weg te laten. Weg met de traditie, tijd voor vernieuwing! Maar er zijn toch wel een aantal mensen die mij gedurende de afgelopen jaren 'gestuurd en gesteund' hebben. Ik kan bijna niet anders dan hun namen hier even vermelden, met het risico dat ik anderen dan weer vergeet.

Bij de mensen die ik zeker wil bedanken hoort natuurlijk op de eerste plaats mijn vader, Bert Tilli. Pap, als tweeling en waterman hebben we al menige discussies gevoerd, maar hoe dan ook, je bent me, samen mat mama, altijd blijven steunen in alles wat ik deed. Als ik weer eens te lang achter elkaar zat te studeren, wisten jullie me telkens weer even af te leiden met een leuk dagje in Antwerpen of een gezellig etentje, dan kon ik er altijd weer even tegen. Bedankt voor alles, en ik hoop dat je er nu ook gerust in bent, het boekje is klaar!

Wat mensen op het werk betreft, zijn er ook de nodige namen die ik moet vermelden. Allereerst natuurlijk mijn promotoren Prof.Dr. Neumann en Prof.Dr. Ramaekers, zonder hun was mijn boekje nooit geworden wat het nu is, de dermatoloog en de celbioloog, niet altijd met elkaar eens, maar uiteindelijk een goede symbiose. Bedankt!

Dr. Gertruud Krekels, niet van het begin al co-promotor, maar wel altijd al betrokken bij het onderzoek. Gertruud, bedankt voor alles. Zeker na het vertrek van Prof. Neumann was jij een steun en mijn link met de kliniek. 
Monique Ummelen en Wendy Dignef verdienen zeker ook een plaatsje in dit dankwoord. Met jullie heb ik de nodige jaren samen doorgebracht op kamertje 5.214. Het was er niet ruim, met zijn drieën, soms met zijn vieren, maar het was er wel altijd gezellig. Ik heb een leuke tijd gehad en zal er altijd met plezier aan terug denken. Ik ben heel blij dat jullie mijn paranimfen willen zijn.

Wat de rest van de crew bij MCB betreft, ook zij hebben hun steentje bijgedragen aan de gezelligheid en stonden altijd paraat als er eender welk probleem was. Bedankt MCB!

Angela Stavast (meisje Kooij) en Jaqueline Braun, de 'Gho-girls', samen hebben we veel plezier beleefd, zowel op het werk als daarbuiten. Ik wil jullie bedanken voor alle goede raad en de enorme steun in moeilijke tijden.

Anneloes, Sander, Stijn, An, Lieven, Jurgen, Sofie, Gaby, Steven, Eric-Jan, Sandra, bedankt allemaal voor jullie interesse in mijn onderzoek.

Mijn schoonouders wil ik graag bedanken voor het feit dat ik hun eetkamer drie maanden lang als bureau heb mogen gebruiken.

Als laatste, maar daarom niet minder belangrijk, wil ik Jan Van Geet bedanken. Lieve 'grote smurf', ook jij bent een enorme steun geweest tijdens een groot deel van mijn AlO-schap. Jij, als geen ander, zag vaak de vertwijfeling als het weer eens tegen zat op het werk. Jij moest mijn frustraties voortdurend aanhoren en jij hebt mij telkens weer moed ingesproken als ik het niet meer zag zitten. Ik had het zeer zeker niet zonder jou gekund en ik ben er trots op dat ik me tegenwoordig jouw vrouw mag noemen.

Bedankt!

Claudia 


\section{Curriculum Vitae}

Claudia Tilli werd geboren op 27 mei 1976 te Maastricht. Na voltooiing van het Gymnasium aan het Trichter College te Maastricht in 1992, werd de studie Scheikunde aangevangen aan het Limburgs Universitair Centrum (LUC) te Diepenbeek, Belgie, waar zij in 1996 het diploma van Kandidaat in de Scheikunde behaalde. Vervolgens heeft zij haar opleiding voortgezet aan de Universitaire Instelling Antwerpen (UIA), waar zij in 1998 het diploma van Licentiaat in de Biochemie behaalde. In het kader van het afstudeertraject, werkte zij van januari 1998 tot mei 1998 aan haar thesis, getiteld 'De rol van apoptose en proliferatie bij het ontstaan van het basaal cel carcinoom', bij de vakgroep Moleculaire Cel Biologie aan de Universiteit Maastricht (UM), onder begeleiding van Dr. G. Schaart en Prof.Dr. F. Ramaekers. In oktober 1998 werd dit onderzoek vervolgd in het kader van een AlO-schap onder begeleiding van promotoren Prof. Dr. M. Neumann en Prof.Dr. F. Ramaekers en co-promotor Dr. G. Krekels. Sinds 6 mei 2003 is zij werkzaam bij Cancer Research UK, Skin Tumour Laboratory in Londen. 



\section{Publications}

Bax expression and growth behavior of basal cell carcinomas C.M.L.J. Tilli, A.J.W. Stavast-Kooy, F.C.S. Ramaekers, H.A.M. Neumann Journal of Cutaneous Pathology (2002): 29 pp 79-87

Lamin expression in normal human skin, actinic keratosis, squamous cell carcinoma and basal cell carcinoma

C.M.L.J. Tilli, F.C.S. Ramaekers, J.L.V. Broers, C.J. Hutchison, H.A.M. Neumann

British Journal of Dermatology (2003): 148 pp 102-109

The garlic derived organosulfur component ajoene decreases basal cell carcinoma tumor size by inducing apoptosis

C.M.L.J. Tilli, A.J.W. Stavast-Kooy, J.D.D. Vuerstaek, M.R.T.M. Thissen, G.A.M. Krekels, F.C.S. Ramaekers, H.A.M. Neumann

Archives of Dermatological Research (2003): 295 number 3 pp 117-123

Human follicular stem cells: Their presence in plucked hair and follicular cell culture

C.G. Gho, J.E.F. Braun, C.M.L.J. Tilli, F.C.S. Ramaekers, H.A.M. Neumann

In press (British Journal of Dermatology)

Molecular cell biology of basal cell carcinoma

C.M.L.J. Tilli, G.A.M. Krekels, M.A.M. Van Steensel, F.C.S. Ramaekers, H.A.M. Neumann

Under revision (British Journal of Dermatology)

Expression of pro- and anti-apoptotic members of the Bcl-2 family and associated proteins in normal human skin and basal cell carcinoma C.M.L.J. Tilli, H.A.M. Neumann, F.C.S. Ramaekers

Accepted for publication (Experimental Dermatology) 


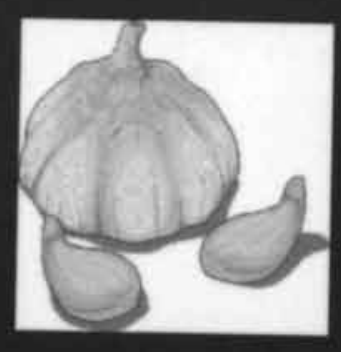

Garlic Soup (The French Kitchen, Harris \& Warde)

\author{
4tbsp olive oil \\ 5 whole garlic bulbs \\ $25 \mathrm{~g}$ flour \\ 1.51 hot water \\ 4 sprigs of thyme \\ sea salt \\ freshly ground black pepper \\ $100 \mathrm{~g}$ thin vermicelli \\ large bunch parsley
}

\title{
Heat the oven to $140^{\circ} \mathrm{C}$
}

Drizzle the oil over a rastin trayand put cut garlic bulbs on it, roast $1-1.5$ hours until soft and golden. Remove garlic from oven and sqeeze out the soft butterly flesh. Put it in a saucepan with juices from roasting tray and mash with a spoon. Over a medium heat, mix in the flour so it absorbs the oil and makes a roux, Slowly pour in the hot water, stirring constantly. Add thyme and seasoning and simmer for 20 minutes. Remove from heat, discard thyme sprigs and use a blender to make the soup smooth. Return to the heat, add vermicelli and cook for 3 minutes.

Add parsley just before serving. 